\title{
A survey of shipping finance research: setting the future research agenda
}

Article

Accepted Version

Creative Commons: Attribution-Noncommercial-No Derivative Works 4.0

Alexandridis, G., Kavussanos, M. G., Kim, C. Y., Tsouknidis, D. A. and Visvikis, I. D. (2018) A survey of shipping finance research: setting the future research agenda. Transportation Research Part E: Logistics and Transportation Review, 115. pp. 164-212. ISSN 1366-5545 doi:

https://doi.org/10.1016/j.tre.2018.04.001 Available at https://centaur.reading.ac.uk/76460/

It is advisable to refer to the publisher's version if you intend to cite from the work. See Guidance on citing.

To link to this article DOI: http://dx.doi.org/10.1016/j.tre.2018.04.001

Publisher: Elsevier

All outputs in CentAUR are protected by Intellectual Property Rights law, including copyright law. Copyright and IPR is retained by the creators or other copyright holders. Terms and conditions for use of this material are defined in the End User Agreement.

www.reading.ac.uk/centaur

\section{CentAUR}


Central Archive at the University of Reading

Reading's research outputs online 


\title{
A Survey of Shipping Finance Research: Setting the Future Research Agenda
}

\author{
George Alexandridis a , Manolis G. Kavussanos ${ }^{\mathrm{b}}$, Chi Y. Kim ${ }^{\mathrm{a}}$, \\ Dimitris A. Tsouknidis ${ }^{c}$, Ilias D. Visvikis ${ }^{\mathrm{d}^{*}+}$ \\ a ICMA Centre, Henley Business School, University of Reading, Whiteknights, Reading RG6 6BA, UK \\ ${ }^{\mathrm{b}}$ Athens University of Economics and Business, 76 Patission St, Athens, TK 10434, Greece \\ ${ }^{\mathrm{c}}$ Department of Commerce, Finance and Shipping, Cyprus University of Technology, 115 Spyrou Araouzou \\ Street, P.O. Box 50329, 3603 Limassol, Cyprus \\ ${ }^{d}$ School of Business Administration, American University of Sharjah, PO Box 26666, \\ Sharjah, United Arab Emirates
}

\begin{abstract}
Financing shipping related investment projects has always been a focal area of debate and research within the international maritime industry since access to funding can determine the competitiveness of a capitalintensive business as well as its success or failure under adverse market conditions. This paper provides, for the first time, a comprehensive and structured survey of all published research in the area of shipping finance and investment. The review spans approximately four decades (1979-2018) of empirical evidence, including 162 studies published in 48 scholarly journals, complemented with select books and book chapters. The study provides a bibliometric analysis and comprehensive synthesis of existing research offering an invaluable source of information for both the academic community and business practice, shaping the future research agenda in shipping finance and investment.
\end{abstract}

JEL Code: G10, G20, G30.

Keywords: Survey analysis; shipping finance and investment; transportation finance; company valuation; corporate governance.

*Corresponding Author: Email: ivisvikis@ aus.edu, Tel: +(971) 65154717 (Ilias D. Visvikis).

${ }^{+}$Authors are listed in alphabetical order. 


\section{Introduction}

The international maritime transportation industry facilitates between $80 \%$ and $90 \%$ of global commodity trade in volume terms and contributes significantly to the welfare and development of nations adding around $\$ 380$ billion a year via freight rates alone to the global economy. ${ }^{1}$ Shipping is among the most cyclical industries with a number of idiosyncratic characteristics that set it apart from other sectors and make it a pivotal one to analyse from a financial economics perspective. Its most notable features are the derived nature of the demand for shipping services, the non-storable nature of the underlying asset (the freight service), the excess volatility and clustering, cyclicality and seasonality associated with freight rates and asset prices, the heightened sensitivity to international supply and demand forces and regulations due to the industry's hyperglobal nature, the fragmented structure of shipping business, as well as its capital and debt intensity. These attributes contribute to a challenging investment and capital raising environment and have triggered voluminous academic and professional research alike. Some of those features have also played a role in attracting the interest of the global investment community, with an ever-increasing number of investment managers introducing shipping transportation as an asset class is their portfolios, facilitating broader access for shipping businesses to the global equity and debt capital markets.

According to data from Clarksons Platou, during the period 2005-2017, the aggregate capital invested in newbuilding vessels alone was more than $\$ 1.5$ trillion, with contracting reaching $\$ 263$ billion during the cycle peak of 2007 . Being among the most capital-intensive industries by employing assets of high commercial value, and with debt typically accounting for the lion's share in the capital structure of a shipping business, requires access to substantial amounts of capital to facilitate the replacement of ageing vessels with new, more efficient and environmentally friendly, as well as to fund an active secondhand market. In turn, this renders corporate financial management decisions particularly important for shipping companies, affecting almost every aspect of shipping businesses, from cash-flow generation capacity (Drobetz et al., 2016b) to corporate ownership/governance structures (Andreou et al., 2014), and ultimately their value creation potential (Kang et al., 2016). Naturally, investment decisions and the associated financing choices entail significant challenges for shipping companies documented in Paine (1990), Stokes (1997), Sloggett (1998), Panayides (2002), Harwood (2006), Syriopoulos (2007), Kavussanos and Visvikis (2016) and Schinas et al. (2015). In fact, the longevity of shipping companies is historically contingent on their access to finance with favourable terms and especially low interest rates (Stopford, 2009). Along these lines, the global financial crisis of 2008 and the ensuing environment of low freight rates further highlighted the importance of access to financing for shipping companies, enabling those with the capacity to finance new projects to weather the storm. At the trough of the cycle, a large number of companies faced financial distress, with Hanjin Shipping's bankruptcy filing in August 2016 providing a notable example. The crisis also emphasised the need for risk management strategies and tools to effectively manage the risks involved in running a shipping business - see for instance, Kavussanos $(2002,2010)$ and Kavussanos and Visvikis (2006a, 2011).

\footnotetext{
${ }^{1}$ The shipping industry's share of global trade range is derived from UNCTAD (2015) and the International Chamber of Shipping (2017). For the sector's contribution to the Global Economy see Global Shipping Market Report in Catalyst Corporate Finance (2016).
} 
Early efforts to finance shipping projects involved mainly own equity, and subsequently relatively small amounts of capital provided by banks. Since the early 1990's a growing number of shipping companies have relied on global capital markets - in a break from traditional sources of financing, such as bank loans - to diversify their funding sources and tap into a wider range of institutional and retail investors. To gain access to global capital markets shipping companies had to evolve from typically family-oriented businesses to corporate entities, which in turn led to a structural transformation and expedited significant improvements in their corporate governance. Given the significance of shipping finance and investment as a specialised area of maritime transportation, the research conducted in this area has been voluminous since the first empirical study published by Yolland (1979). In spite of the impact of shipping finance to both the academic community and business practice, to date, and to the best of our knowledge, there is no comprehensive survey of published research in this area. Notwithstanding, a number of studies have attempted to address conceptualization, methodological issues, theoretical developments, academic taxonomy and future research directions in areas relevant to transportation, such as quantitative modelling in shipping (Glen, 2006); port management (Steenken et al., 2004; Pallis et al., 2010; Pallis et al., 2011; Woo et al., 2011; Woo et al., 2012; $\mathrm{Ng}$, 2013), logistics and supply chain management (Mentzer and Kahn, 1995; Ho et al., 2002; Burgess et al., 2006; Panayides, 2006), shipping freight derivatives (Kavussanos and Visvikis, 2006b; 2008), ocean container shipping (Lau et al., 2013; Lau et al., 2017; Lee and Song, 2017), and maritime transport (Shi and Li, 2017).

To fill this research gap, the current study provides a comprehensive survey and analysis of the existing research by examining, to the best of our knowledge, all academic studies published in scholarly journals in the area of shipping finance and investments during the period 1979-2018 (April), complemented with select books and book chapters, and provides suggestions in an effort to set the future research agenda. In order to provide a wide-ranging review of the literature we first identify all studies related to shipping finance and investments published in scientific journals. We further scan the references of all these studies to identify other relevant research published in journals within various social science areas, such as finance, economics and management. This process yields 162 papers published in 48 scholarly journals. The journal titles along with aggregate paper counts for four sub-periods are presented in Table 1. It turns out that the majority of shipping finance and investment studies have been published in transportation and maritime academic journals. Notably, shipping finance research is concentrated in a small number of journals with 94 out of 162 studies having been published in: Maritime Policy and Management (38 paper counts), Transportation Research Part E: Logistics and Transportation Review (35 paper counts) and Maritime Economics and Logistics (22 paper counts). We further classify the papers examined in this paper into four major research areas inspired by the classification structure typically adopted in the mainstream corporate finance literature. These are: (a) sources of finance and capital structure in shipping, (b) shipping investment and valuation methods, (c) corporate governance of shipping companies, and (d) risk measurement and management in shipping.

We next conduct a comprehensive bibliometric analysis of the related academic literature in shipping finance and investments which aims to provide additional information on the frequency 
of publications in each research area identified, the methodological approaches utilised, coauthorship associations and research impact. In the second part of the paper we provide a comprehensive review of the literature and critical discussion of the empirical evidence on the four aforementioned distinct research areas. Each section identifies pivotal gaps in the literature along with potential paths for further research. All sections include a summary of the research designs and findings, tabulated concisely for ease of reference.

This survey paper contributes to the extant literature in several important ways. First, to the best of our knowledge, it is the first to offer a comprehensive overview of the research findings in the area of shipping finance. Second, the bibliometric analysis performed highlights more succinctly the research developments in the area of shipping finance. Third, the paper provides a comprehensive synthesis of all published research in shipping finance and investments and offers an invaluable source of information for both the academic community and business practice. Finally, it shapes the future research agenda on shipping finance and investments by critically discussing the gaps in the extant literature and the potential avenues for further research. The rest of this paper is organised as follows. Section 2 provides a bibliometric overview of all studies included in this survey. Sections 3 to 6 offers comprehensive review of the literature, key empirical findings and suggestions for future research on the four major research areas in shipping finance and investments. Finally, Section 7 concludes the paper.

\section{Bibliometric Review}

As a first step, we provide an overview of the evolution of the literature in the area of shipping finance, investments and risk management, and identify trends in key bibliometric statistics on the research topics covered, the methodologies employed, research impact, and co-authorship collaborations. Table 2 provides a classification of existing shipping finance and investment literature by research topic, journal discipline and regional focus. In terms of research topics (see Panel A) it appears that during 1979-2018, risk measurement and management in shipping (61 papers) and shipping investment/valuation methods (61 papers) have attracted significant attention, followed by sources of finance/capital structure in shipping (34 papers). Moreover, the focus of shipping finance research seems to have evolved through time. For instance, during the pre-1990s period only three studies examined valuation methods. Thereafter, the literature has progressively expanded on alternative topics that fall broadly within the areas of capital structure, inorganic investments (Mergers \& Acquisitions - M\&As), corporate governance and risk management. Further, Panel B shows the distribution of studies published in shipping finance partitioned by journal discipline. Journals in the broad transportation and maritime disciplines account for the vast majority of academic publications (73\%). Academic journals in the fields of finance, economics, operations and management have also published papers focusing on shipping finance and investment, although their share is significantly lower; yet it has gradually increased post-2009.

Finally, Panel C classifies the studies by the regional focus of the empirical investigation. Evidently, the regional scope of the shipping finance literature is primarily U.S. oriented, especially for studies examining samples of listed shipping companies. This can be attributed to the fact that the U.S. money and capital markets have been developed much earlier and, partially 
due to their size, cater for a more suitable financial environment for shipping companies to seek capital. As a result, Initial Public Offerings (IPOs) and high yield bond issues have taken place mainly in U.S. markets since the mid-90s. Another contributing factor is that, depending on the research question examined, there is evidently broader data availability for U.S. listed shipping companies. This can in turn be attributed to more stringent regulations in U.S. capital markets, requiring full disclosure of corporate information for the purpose of capital raising.

Further, we group the studies included in this survey paper according to the methodological approach they follow. To that end, we adopt a classification scheme in line with the one in the field of operations management research put forward by Wacker (1998). The classification differentiates between two main research approaches. The analytical approach includes deductive methods ("drawing logically certain conclusions through the process of reasoning"), while the empirical approach includes inductive methods ("deriving general principles from specific observations"). Each approach comprises three sub-categories; the analytical approach consists of conceptual, mathematical and statistical methods while the empirical approach includes experimental, statistical and case studies.

Table 3, Panel A shows the distribution of shipping finance studies classified according to Wacker's (1998) framework. The vast majority of studies (131 paper counts or $81 \%$ of all papers) employ empirical methodologies, primarily using statistical measures to provide empirical evidence. This pattern is rather different from that observed in survey studies in other shippingrelated fields, such as for port studies (Woo et al., 2011) and logistics / Supply Chain Management (SCM) studies (Burgess et al., 2006), where analytical-conceptual research designs are the most popular among the methodological approaches adopted. Table 3, Panel B classifies studies by the research methodology employed with the most popular by and large being economic modelling (122 studies or 75\% of all studies examined). Table 3, Panel C takes a step further in the classification of shipping finance literature by focusing specifically on the data analysis techniques utilised. The most frequently employed technique for data analysis is the classical regression model (47 papers or $29 \%$ of the total), followed by the error correction model (23 papers or $14 \%$ of the total), real options modelling (17 papers or $10 \%$ of the total), descriptive analysis (14 papers or $9 \%$ of the total), autoregressive conditional heteroscedasticity modelling (12 paper or $7 \%$ of the total) and event study analysis (8 papers or 5\% of the total). The recent surge in the popularity of the event study analysis and options pricing models can be attributed to the emergence of new research strands in the shipping finance literature, such as Mergers \& Acquisitions (M\&A), IPOs, and Real Option Analysis (ROA).

Finally, Table 4, Panel A presents additional information for the studies examined, on the number of authors and the type of co-authorship, and in Panel B on their research impact in terms of citations. The number of authors per paper has gradually increased over the past four decades from an average of one author during pre-1990s to 2.7 during post-2000s. Figure 1 illustrates research collaborations in the shipping finance literature during 1979-2018 based on social network analysis metrics. The nodes represent authors of the papers examined in this survey while the edges (links) indicate co-occurrence of those authors with others in the same scholarly publication (i.e. co-authorship). While the number of edges attached to a node ('degree' of a node) indicates the number of co-authorship relations of the corresponding author, the thickness 
of an edge ('weight' of an edge) captures the frequency of collaborations between a pair of authors. The node size shows the 'weighted degree', the sum of the weights of edges attached to that node. Therefore, a larger node reflects a researcher with a higher number of research collaborations. On the other hand, a researcher with a smaller collaboration network for scholarly publications is associated with a smaller node. In each graph, the nodes of the top 15 researchers in terms of weighted degree are labelled with their names. Further, the thickness of an edge captures the frequency of collaborations between a pair of authors. The figure depicts a clear tendency that collaborations have recently become more commonplace among shipping finance researchers. In the first period (pre-2000s), collaborations seem to be highly scattered as the vast majority of scholarly publications at that time were authored by a single or a pair of authors. In contrast, a gradual emergence of more extensive research collaborations is evident in the next two periods (2000s and post-2000s), where the average of the weighted degree increased from 1.1 in the pre-2000s period to 3.1 in the 2000 s and 3.2 in the post-2000s periods. This is consistent with the findings of Lau et al. (2017), a paper on the evolution of the co-authorship network in the container shipping research area. They argue that the development of connectivity among academic researchers can be largely attributed to rapid progresses in telecommunications and people's mobility (e.g. the development of international academic conferences and global networks of researchers). The "All period view" offers an overview of research collaborations in the shipping finance area during the sample period (1979-2018). Given the observation that the affiliations of the vast majority of the most collaborative researchers (13 out of 15) are in Europe, it is obvious that the documented expansion of research networks in the shipping finance area largely involves European academic institutions.

Along with the increase in the number of authors per paper, the extent of international collaborations has also increased notably, possibly attributed to recent globalisation trends along with the authentically international nature of the shipping industry. In addition, a growing number of papers has more recently been co-authored by both academics and practitioners which points to an acceleration in interconnectedness between academia and the industry. In terms of research impact reported in Table 4, Panel B, the average paper is cited 24.4 times throughout the entire sample period. The average annual number of citations has increased from 0.1 during pre-1990s to 2.7 during post-2000s, indicating that there is an increasing interest in the shipping finance area from the academic community. Finally, the Appendix presents the number of publications per author in shipping finance research. The bibliometric analysis presented in this section illustrates the ways in which the literature on shipping finance, investments and risk management has evolved over time in terms of topics, academic disciplines, methodologies, collaborations, and research impact. It is evident that researchers in this area have gradually addressed more diverse topics and expanded their networks and extent of collaborations through more international co-authorships. The next sections provide a thorough critical review of the literature, structured along the four major research areas in shipping finance and investments discussed earlier.

\section{Sources of Finance and Capital Structure in Shipping}

The inherently capital-intensive nature of the shipping industry places at the forefront of the shipping finance research agenda issues directly associated with shipping financial management 
decisions, such as the financing choice and optimal capital structure. The sector's distinctive characteristics, among which capital intensiveness, play a key role in these decisions. Contracting a single new-building vessel typically requires capital expenditure of more than \$40mil (depending on size, type and market conditions), aggregating to total investment of around $\$ 130$ billion per annum, while there is also an active second-hand S\&P market, adding further to the heightened demand for capital. ${ }^{2}$ On top of the capital intensiveness and high degree of liquidity, the shipping industry is also known for its extensive fluctuations in vessel revenues, operating cash-flows, and asset values, which altogether give rise to a challenging business and financing environment for shipping companies (see Kavussanos, 2002 and Kavussanos and Visvikis, 2006a). Thus, becoming adept at striking an optimal capital mix that offers financial flexibility to tackle the rather severe troughs of shipping business cycles has become a central issue for shipping businesses. Given the long-term economic life of shipping assets/projects (vessels) in shipping, debt has traditionally been the primary financing source. In the $1980 \mathrm{~s}$, the shipping industry raised as much as $75 \%$ of its external funding from banks in the form of loans, while bonds and public equity accounted for only about $5 \% .{ }^{3}$ Yet, shipping finance has seen a rather radical transformation since the early 1990s which, among along other factors, has been linked to the evolution of shipping companies from predominantly family businesses to more corporate-oriented structures, and was driven by their ever increasing reliance on global capital markets. The trend towards further diversification of financing sources was further shaped by the tight credit markets in the aftermath of the 2008 global financial crisis.

Figure 2 depicts the evolution of shipping finance sources globally during the period 2007-2017. The collapse of new-building vessel contracting and second-hand purchases along with a steep surge in global economic risk levels have led to a sharp drop in the volume of bank debt (loans) raised by shipping companies in 2009. Following the onset of the global financial crisis and the ensuing shipping market crash, ship-lending banks reduced their exposure to the shipping industry to minimise their losses. In addition, they introduced more stringent terms to manage credit risk when offering a credit facility such as requiring significantly lower Loan-to-Value (LTV) ratios, shorter amortization maturities (e.g. 5 years), higher margin spreads and more substantial covenants and collaterals (see Kavussanos and Tsouknidis, 2016). During this period, high-yield bond issues and Private Equity (PE) gained ground as alternative sources of capital (see Kavussanos and Tsouknidis, 2014). Overall, the sources of funding in the shipping industry and the optimal financing mix along with their evolution are arguably at the core of shipping finance literature and have triggered a significant amount of research.

\subsection{Shipping Bank Loans and Credit Risk Analysis}

As shown in Figure 2, shipping bank loans have traditionally been the predominant financing source in the shipping industry, accounting for approximately $75 \%$ of the total ship-funding requirements during the period 2007-2017. The popularity of bank borrowings among shipowning companies can be explained by: (i) the lower cost and more readily available nature of

\footnotetext{
${ }^{2}$ According to Clarksons Platou, over 1,000 vessels per annum on average changed hands during the period 20052015.

${ }^{3}$ ABN AMRO (2011), Shipping Finance and Investment: Current Trends in Ship Finance, $3^{\text {rd }}$ Mare Forum in Ship Finance, Istanbul, $22^{\text {nd }}$ March.
} 
bank loans which are highly desirable features among shipowners given the capital intensive nature of the business and the short-lived investment opportunities involved; (ii) relying on debt as a funding source does not affect the ownership structure of a shipping company, which is important given that shipping businesses are typically reluctant to endure significant changes in their traditional family oriented and highly concentrated ownership structures, (iii) raising funds through bank loans does not require the public disclosure of (confidential) strategic, financial and operational information, unlike for instance in IPOs and corporate bond issues (Kavussanos and Tsouknidis, 2014; 2016); and (iv) historically, shipping bank loans have been granted on the basis of relationship banking, based on which a long-term rapport is established on amicable trust and information sharing between the obligor and the bank (Gavalas and Syriopoulos, 2014; Kavussanos and Tsouknidis, 2016; Mitroussi et al., 2016).

Existing literature on this topic has primarily concentrated on the default risk assessment of shipping bank loan agreements and examined the impact of qualitative factors, such as the owners' reputation, background, business commitment, know-how and credit history; along with quantitative ones, such as their financial position, market share, and fleet composition. ${ }^{4}$ Early efforts utilise the Multi-Criteria Decision Making (MCDM) approach - a process of decisionmaking optimisation with multiple criteria - in order to assess default risk in shipping bank loans. Along these lines, Dimitras et al. (2002) employ the Utilities Additives Discriminants (UTADIS) method to assess the default risk of 17 shipping bank loans, approved over the period 1999$2001 .^{5}$ The authors consider a wide set of credit criteria utilized in credit assessment, and assign weights based on the subjective opinion of financial professionals from a specific consulting firm. The UTADIS method is then used to specify a utility function for each group of bank loan applications based on their default risk and the cut-off utility level for granting a loan. The study finds that the most important factors in the assessment of shipping bank loans' default risk are the ownership structure and the quality/experience of the management team (34\%), followed by the credit history of the obligor (20\%) and fleet characteristics (12\%). However, the authors also acknowledge that the weights and utility thresholds employed can be largely contingent on the sample examined and the time-varying risk appetite of ship-lending banks.

In a related study, Gavalas and Syriopoulos (2014) also examine factors used in the assessment of shipping loans' default risk based on primary data, collected from a bank survey questionnaire during the period April-June 2012. The authors survey a sample of 16 managers to capture their perception on the importance of default risk drivers in shipping bank loan agreements. Having specified an initial set of credit criteria based on the survey conducted, Gavalas and Syriopoulos (2014) rely on the UTADIS method to determine a utility function and the cut-off utility thresholds for granting a loan in a manner similar to Dimitras et al. (2002). Results show that the credit rating migration probability (i.e. the probability of moving from one credit rating threshold to another), the debt-to-equity and asset coverage ratios are the most relevant

\footnotetext{
${ }^{4}$ Another strand of literature looks at the evaluation of default risk of the charter market to lending banks. Adland and Jia (2008) investigate how charter market default risk varies in relation to freight market conditions, charter duration, and the charterer's financial standing. There is a risk-premium attributable to default risk, which is positively related to freight rate level and charter duration.

${ }^{5}$ The UTADIS method is part of the wider family of the UTA multi-criteria methods (see Devaud et al., 1980). Given a pre-specified grouping of criteria - in this case credit loan criteria - the UTADIS method seeks to provide an additive utility function and the corresponding utility thresholds when evaluating default risk.
} 
factors when assessing default risk. One needs to bear in mind however that the results from a survey questionnaire need to be interpreted with caution, since a manager's perception of the significance of relevant factors when assessing a loan agreement may be subjective. Gavalas and Syriopoulos (2016) propose a multi-criteria integrated framework for the preferential ranking and optimal selection of shipping (dry bulk and tanker) loan collaterals, based on the evaluation and weighting of a set of criteria; such as, asset cash flow (freight rate volatility, ship age), asset value (vessel market value, construction shipyard, scrap value) and financial recourse (asset coverage ratio, loan-to-value ratio). Such an optimal selection supports the enduring loan performance, and as such, it results to a higher quality - lower risk bank loan portfolios.

As discussed earlier in the paper, the landscape of bank financing in the shipping industry has changed radically after the onset of the global financial crisis. As shown in Figure 2, bank financing tumbled after 2008 and gradually retreated again significantly during the last few years. The rising uncertainty in the global economy along with the lack of liquidity in the banking sector (Santos, 2011) led to a significant increase of default risk in capital markets which, eventually, induced a number defaults among banks and bank-debt dependent businesses (Chava and Purnanandam, 2011). This adverse business environment also led to the restructuring of shipping bank loans and made the empirical investigation of their default risk drivers a focal research avenue for ship-lending financial institutions and other shipping market participants.

Along these lines, Kavussanos and Tsouknidis (2016) examined the default risk drivers of shipping bank loans by using a logit credit scoring model for the first time in the shipping finance literature. The authors use a proprietary dataset compiled from the credit portfolio of a Greek commercial ship-lending bank, which includes 128 loans issued to 63 shipping companies over a 14-year period spanning 1997 to 2011. The sample of loans examined involves dry bulk, tanker, container and gas carriers. The authors find that the most significant factors explaining bank loan defaults are industry specific and capture current and expected (forward-looking) conditions in freight markets, the risk appetite of shipowners proxied by the chartering policy employed, as well as a pricing variable - the arrangement fee over the amount of loan (see also, Chava and Purnanandam, 2011). In a similar study, Mitroussi et al. (2016) utilize a logit credit scoring methodology to examine the performance risk drivers for a sample of 30 shipping bank loans for dry bulk vessels, during the period 2005-2009, and document that market conditions and chartering policy are important factors in determining the performance risk of shipping bank loans.

Further, Lozinskaia et al. (2017) find that both financial and non-financial variables are important in assessing the credit worthiness of shipping companies and specifically that the probability of default increases with one-year lags of Tobin's $Q$ (proxied by the ratio Market value / Book value) and EBITDA (Earnings Before Interest, Tax, Dividends and Amortisation) and decreases with one-year lags of the Total Assets (size) of the company and the growth in GDP (Gross Domestic Product). Gong et al. (2013) conducted a questionnaire-based survey of 12 ship-lending banks in Hong Kong over the period 2008-2009 and show that the loan quality and collateral used are the most important factors in assessing default risk. Finally, in a similar study, Lee and Pak (2018) examine bankers' underwriting attitude towards shipping syndicated loans in the post-2008 financial crisis period. Based on a survey of 41 shipping bankers in 11 
countries, they find that corporate recourse related criteria (e.g. the shipowner's financial strength and business history as well as the bank-firm relationship) are the most important in in ship-lending decisions, followed by asset cash-flow and asset value. The authors argue that the relative importance of corporate recourse factors implies that shipping bankers perceive shipping loans to be safer than traditional asset-backed financing or project-financing.

The fact that the most important default drivers of shipping bank loans are rather industryspecific, is generally at odds with findings in the general finance literature indicating that financial characteristics of obligors (e.g. financial structure, profitability and liquidity) and other features (e.g. collateralised loans and bank-borrower relationship) are more important in predicting the probability of default in bank loans (see Jiménez and Saurina, 2004; Bonfim, 2009; and Chang et al. 2014, among others). This can be attributed to the pronounced cyclicality and excess volatility of freight rates (Stopford, 2009), which, along with high levels of debt (Drobetz et al., 2016b), can increase the likelihood of default during bear market conditions.

A shortcoming of the literature on the assessment of default risk in shipping bank loan agreements stems from the lack of publicly available data on such deals, sufficient enough to represent the global portfolio of shipping bank loans. Future studies can address this gap by focusing on larger shipping bank loans portfolios, utilizing proprietary data, ideally across different regions of the world. This is especially important from a regulatory point of view, since banks operating in different countries/regions are subject to different regulatory frameworks and authorities. Such divergence in regulatory frameworks may exert varying degrees of pressure on financial institutions to reduce their exposures, especially to risky industries, such as the shipping sector. This can be primarily implemented by imposing stricter - and less favorable for shipowners - terms on shipping bank loan agreements.

Further, given the deadlock in bank credit and the tightened financial regulations in the postcrisis period, another important question is whether bank lending is likely to remain the primary source of ship financing. Along these lines, Gong et al.'s (2013) survey results reflect that banks adopted measures to limit their exposure to the shipping industry, as their lending capacity was hampered by the weak shipping market conditions and the implementation of new banking regulations, such as, the stricter capital requirements under BASEL III by the Basel Committee on Banking Supervision aiming at tightening the regulation, monitoring and risk management across the banking industry. Thus, future research can offer insights on this issue by exploring whether the bank lending gap was effectively a positive development for the shipping industry by putting the breaks to contracting, restoring the demand-supply balance, as well as, to what extent were alternative sources of shipping finance effective in filling the bank-lending gap. The conditions under which bank lending in the shipping industry can potentially recover also remains an interesting research question.

\subsection{Public Debt and Shipping Bond Pricing}

Financing shipping projects by tapping the public debt market has gained popularity after the 1990s. Sea Containers Ltd. was the first shipping company to issue public debt of $\$ 125$ million back in 1992. Figure 2 shows that bond issues account, on average for $14 \%$ of the total capital 
raised for shipping investments over the period 2007-2017. Issuing public debt has gained pace as a source of funding for the shipping industry for several reasons. First, a large number of shipping companies evolved from traditional family businesses to corporate entities with better access to debt capital markets. Second, shipping bonds often provide borrowers with more flexible terms compared to shipping bank loans since ship-lending banks generally require floating interest rates and high collateral value; typically, of the entire vessel being financed. Third, issuing public debt involves a less cumbersome and time-consuming process relative to issuing equity capital. Fourth, bond issues tend to leave the ownership structure of the shipping company unchanged, whereas issuing equity capital comes with an ownership dilution effect. Fifth, raising funds through bond issues offer borrowers the opportunity to realise tax benefits. ${ }^{6}$ Sixth, bond issues can provide an alternative to traditional bank finance during periods of credit crunches. Seventh, the bulk of the repayment of a bond issue becomes due at its maturity, thus allowing for more cash flow flexibility during the repayment schedule.

Despite their benefits, shipping bonds tend to expose shipping investors to higher financial distress costs given the additional complication and cost associated with re-negotiating their terms with bondholders relative to shipping bank loans. Another primary concern for shipping companies issuing public debt is its relatively higher cost of capital relative to shipping bank loans. This is reflected in the so-called bond spread, defined as the spread over and above the risk-free rate, required by bond investors as compensation for the risk premium they incur. Kavussanos and Tsouknidis (2014) document that, on average, the spreads of shipping bonds globally are 2-3 times higher than the typical corporate bond spreads in other sectors, as reported in Friewald et al. (2012) and Helwege et al. (2014), placing them well into the high-yield segment of all bond issues. One explanation for carrying higher spreads is that bondholders need to be compensated for the additional risks they incur stemming from the distinctive characteristics of the shipping industry outlined earlier in the paper.

The extant literature investigating the factors explaining shipping bond spreads is relatively thin. Leggate (2000) focuses on 33 newly issued European shipping bonds, over the period 1997 to 2000 and reports a negative (positive) relation between credit ratings and bond coupons (shipping market conditions). Grammenos and Arkoulis (2003) explore bond spread determinants of 30 high yield offerings issued by U.S. listed shipping companies during the period 1993-2008 and document that shipping bond spreads are positively (negatively) related to the issuer's financial leverage (credit ratings and shipping market conditions). However, these studies concentrate on the cross-sectional variation in bond spreads, thus ignoring the time dimension that might change the causality relationships identified. Capturing the potential effect of the time dimension, Grammenos et al. (2007) examine shipping bond spread determinants by estimating panel data regressions. The authors analyse a sample of 40 seasoned high yield bond offerings issued by U.S. listed shipping companies during the period 1998-2002. They report that the main drivers of shipping bond spreads are credit ratings, changes in shipping market earnings, which is in line with their previous studies, as well as the term to maturity, the yield of 10-year treasury bonds and the yield of the Merrill Lynch single-B index.

\footnotetext{
${ }^{6}$ We note that a number of these benefits including tax-shields and ownership structure effects apply to debt in general, and not just corporate bonds.
} 
In a related study, Grammenos et al. (2008) examine the default risk drivers of shipping bonds, instead of bond spread determinants and find that the key financial variables associated with the probability of default are: the gearing ratio, the amount (value) raised through the bond issue over total assets, the working capital-to-total assets ratio, the retained earnings-to-total assets ratio and an industry specific variable capturing shipping market conditions at the time of issuance. Identifying the relevant factors explaining the observed defaults in shipping bond issues can be used to predict a-priori the probability of default. The authors, assess the predictive ability of their model in a Type I and Type II errors framework (see Zavgren, 1983). ${ }^{7}$ Overall, when forecasting in-sample, their model predicts correctly $96 \%$ of the observations with a Type II error of $2.70 \%$ and Type I error of $7.69 \%$.

Finally, Kavussanos and Tsouknidis (2014) provide new empirical evidence on the determinants of global shipping bond spreads. They utilize a sample of 54 shipping bonds issued by listed shipping companies around the world during the period 2003-2010 along with panel data regressions with two-way adjusted clustered standard errors, as in Petersen (2009). The authors report that the liquidity and the credit rating of the bond issue, the volatility of the stock market, the bond markets' cyclicality and freight earnings are the main determinants of shipping bond spreads. These results suggest that shipping bond spreads also reflect the cyclicality observed in freight rates under different shipping market conditions which corroborates the key role cyclicality plays in shipping (see Kavussanos and Alizadeh, 2001 and Stopford, 2009). The study is the first to examine the explanatory power of the cyclical bond issuers' index - the Global Services Cyclical Index, GISC - on shipping bond spreads and finds it to be significant (insignificant) during the pre-crisis (crisis) period. A possible explanation is that under "normal" market conditions, bond investors paid more attention to the cyclical variables prevailing in shipping when compared to the global financial crisis period. These bond spread determinants are different from those reported in the general corporate bond pricing literature (for more details see Dick-Nielsen, et al. 2012). Specifically, shipping bond spreads changes are affected by the market-wide volatility, as measured by the VIX Index; the GISC cyclical bond issuers' index, that reflects the cyclicality of the shipping industry; changes in the market value of the bond reflecting liquidity; changes in the bond rating - reflecting changes in the default riskiness of the bond; and lagged values of the shipping industry-specific freight earnings variable.

Given the continuous growth of debt capital markets as a financing source for the shipping industry, future research on this area would benefit from assessing the role of liquidity risk in bond spreads. Existing studies in the finance literature (such as, Chen et al., 2007; Dick-Nielsen, et al., 2012, among others) utilise measures such as the number of trades for each bond per day/month, the number of zero trading days, an Amihud (2002)-inspired measure for bonds defined as the ratio of the daily absolute change in the bond's price over the daily volume of the bond, and the bid-ask spread using Roll's (1984) measure. ${ }^{8}$ Since the evidence in the general corporate bond pricing literature strongly points to the existence of large liquidity risk premia in corpora rate bond spreads, it would be interesting to assess if this is also the case for shipping

\footnotetext{
${ }^{7}$ A Type I error occurs when the model predicts that a bond will not default when it actually does. A Type II error occurs when the model predicts that a bond will default when it does not. Naturally, Type I error is costlier than Type II error.

${ }^{8}$ For details on bond liquidity measures, see Dick-Nielsen et al. (2012).
} 
bond issues and the extent to which other shipping industry related characteristics are important in explaining the observed variation in shipping bond spreads.

\subsection{Public Equity and IPO Performance}

It was only in the 1990's that the shipping industry started tapping the equity market as a funding source and since then a growing number of shipping companies consider public equity capital a vital source of capital. As Figure 2 illustrates, the estimated share of public equity, which includes both IPOs and follow-on offers (as well as private placements and preferred equity), in shipping finance is about $8 \%$ during the period 2007-2017. The comparative advantage of equity financing over debt comes from its strategic flexibility; that is, it comprises a sustainable financial management strategy regardless of shipping market conditions, offering continuity in funding. This section reviews the empirical evidence on public equity financing and shipping IPO performance.

One of the stylised facts in companies' public debut is the initial under-pricing, which is reflected in a significantly higher closing price on the first day of trading than the initial offer price. An under-priced offering indicates that a company sells its shares at a discount, which represents a cost to existing owners. IPO underpricing is also documented in the shipping industry. Grammenos and Marcoulis (1996) is the first study to examine shipping IPOs' first day (unadjusted) return, and find this to be 5.32\% across seven countries. Cullinane and Gong (2002) report severe underpricing in shipping IPOs in China mainland and Hong Kong of $104.95 \%$ and 19.17\%, respectively, during the period 1972-1998. According to Cullinane and Gong (2002), Miller's (1977) overvaluation setting where extreme first day returns can be driven by high divergence of opinion among investors about the value of transportation stocks in China, may explain the results. This is in line with findings for Chinese IPOs by Jia, et al. (2017) and may be attributed to the emerging nature of the Chinese market. Shipping IPOs in other markets have been shown to exhibit relatively lower degrees of under-pricing. Accordingly, Merikas et al. (2009) find that shipping IPOs in fourteen major stock exchanges around the world during the period 1984-2007 are under-priced by 17.69\% on average. However, Merikas et al. (2010) and Grammenos and Papapostolou (2012b) report under-pricing of only $4.44 \%$ and $2.69 \%$, respectively for the U.S. shipping IPOs market during 1987-2008. Satta (2017) investigates the determinants of short-run IPO performance of port operators and reports that underpricing is negatively associated with company characteristics (age of issuers), deal-specific features (number of underwriters and reputation of the leading underwriters) and country factors (issuers headquartered in countries with well-rooted maritime traditions or efficient institutional environments).

A well-documented anomaly of IPOs is their long-term underperformance; that is, the observation that companies going public tend to underperform the market or peers in the years following the listing (see Loughran and Ritter, 1995; Ritter and Welch, 2002). Grammenos and Arkoulis (1999) examine the performance shipping IPOs for a two-year holding post-listing window and find that they underperform the home index by $36.79 \%$. Moreover, the performance is positively (negatively) related to the gearing ratio (fleet age profile of the company). Merikas 
et al. (2009) examine the short- and long-run performance of a sample of 143 shipping IPOs during the period 1984-2007 which points to an underpricing of $17.69 \%$. This relatively small underpricing is found to be positively related to the age of the company, the reputation of the stock exchange where the IPO took place and the stock market's conditions during the period the shipping firm went public. Similarly, post-IPO underperformance is also documented in the initial offerings of port operators. For example, Satta et al. (2017) examine a sample of 93 IPOs in the port industry over the period 2000-2015. Overall, the sample of port IPOs examined experienced poor long-term performance, as both Buy-and-Hold Abnormal Returns (BHARs) and Cumulative Abnormal Return (CARs) measures are negative for 24-month and a 36-month time-frames. Favourable market conditions have been found to increase stock prices and to reduce risk perception in the port industry, where a number of institutional investors operate (Rodrigue et al., 2011). Regarding institutional factors, IPOs issued in host capital markets with a high level of political stability display higher long-term performance. Finally, industry-specific characteristics, such as IPOs issued by port authorities in countries which started port liberalization and privatization processes for a long time, exhibit lower 36-month BAHRs and CARs.

The empirical literature on public listing of shipping companies suggests that IPO performance is driven by industry characteristics, such as shipping market conditions and freight rate volatility, as well as, general economic factors. Yet, the impact of some important drivers of IPO performance identified in the general finance literature has not been investigated in a shipping IPO setting. Given the importance of corporate governance and ownership structure in the shipping industry, future research may focus on the impact of these characteristics on post-IPO performance. For instance, McBain and Krause (1989) and Bruton et al. (2010) document a significant effect of insider ownership and ownership concentration on IPO's performance. Since a large number of shipowning companies are typically family-owned businesses, it would be interesting to examine the role of ownership concentration in shipping and post-IPO performance. In addition, if superior corporate governance can result in better planned and executed IPOs, we should observe a positive association between governance metrics and IPO performance. Political connections and networks provide another interesting research avenue for the shipping industry. Along these lines, Fan et al. (2007) examine a sample of partially privatized companies in China and report that companies with politically connected CEOs underperform their nonpolitically-connected counterparts by almost $18 \%$ based on three-year post-IPO stock returns while they exhibit inferior three-year post-IPO earnings growth, sales growth, and change in returns on sales.

Further, raising funds from capital markets has been relatively scarce during the post-crisis period. Whether the shipping IPO market can potentially recover and under what conditions remain open questions. ${ }^{9,10}$ Pribor and Lind (2016) argue that the success of shipping IPOs during the post-crisis period is largely contingent on segment-specific drivers given that roughly half of shipping IPOs in the U.S. during the period 2013-2015 were carried out by gas carriers during relatively favourable freight market conditions. Along these lines, the impact of market conditions on shipping public equity markets deserves further investigation. Moreover,

\footnotetext{
${ }^{9}$ Lloyd's List, 'Shipping IPOs will return', March 21, 2017.

${ }^{10}$ Shipping Watch, 'Lloyd Fonds: Shipping markets too weak for IPO', March 22, 2016.
} 
identifying the key drivers of successful IPOs within the different shipping segments is an important future research topic. The growth of private placements among listed shipping companies (so called, Private Investment in Public Equity - PIPE) in 2016 was significant for the first time. ${ }^{11}$ Due to its distinct characteristics, that is, shorter issuance time-frame and lower costs, a PIPE can be a good financing option for companies facing difficulties in raising equity capital. ${ }^{12}$ Typically, companies with high levels of information asymmetry and poor operating performance tend to prefer PIPEs over public offerings. Future research can shed light over the pros and cons of this alternative financing form.

\subsection{Shipping Funds and their Performance}

Shipping funds constitute a distinct source of finance for the shipping industry. Vessels financed through shipping funds are off-balance sheet assets, and thus, offer financial flexibility and tax benefits to shipping companies. The German Kommanditgesellschaft (KG) and Norwegian Kommandittselskap (KS) have been widely regarded as the most popular forms of shipping funds, as from 2000 to 2008 alone, approximately $€ 20$ billions of equity investment in commercial ships has been raised in the German KG market alone (Johns and Sturm, 2015). However, since the post-Lehman era, there is limited new financing activity in the primary KG market (Simic et al., 2016). KG and KS funds are tax-driven leasing schemes, where typically a Special Purpose Company (SPC) is established for the purpose of owning and chartering a single vessel. Prior to 2008, many shipping companies were significantly expanding their fleets via ordering newbuilding vessels or purchasing second-hand ones. Especially, the German KG scheme was responsible for the financing of almost $26 \%$ of all containership newbuilding orders during the period 2006-2008 and a third of the world fleet as of March 2013. ${ }^{13}$ However, after the KG market collapsed in the post-2008 period, more than 300 one-ship companies funded via the KG financing scheme were declared insolvent, which indicated that the market was underperforming. ${ }^{14,15}$

Shipping funds are closed-end funds legally treated as limited partnerships and are not publicly traded once their target capital amounts are raised. Accordingly, potential investors in shipping funds have limited information regarding the risk-return profile of their investment. These features lead to lack of reliable performance data due to non-observable market prices during the lifetime of the funds. The lack of observable market prices is also the reason why only few studies have focused the shipping funds market. Drobetz and Tegtmeier (2013) construct a performance index for the German KG funds for the container, dry bulk and tanker shipping subsegments, based on aggregate data for 323 one-ship companies over the period 1996-2007. The authors compare its statistical properties with those of existing shipping-related indices and report that the variation of the constructed index is more dependent on vessel price indices, such as Clarksons' newbuilding price index and Clarksons' second-hand price index than to freight

\footnotetext{
${ }^{11}$ IHS Fairplay, 'Shipping sees more signs of life in US capital markets', June 10, 2016.

${ }^{12}$ Hogboom, J. D. 'Private investment in public equity: An overview', New Jersey Law Journal, 177(7), August 16, 2004.

${ }^{13}$ Journal of Commerce, 'Container ship financing remains available despite collapse of Germany's KG system; March $12^{\text {th }}, 2013$.

${ }^{14}$ Lloyd's List, 'KG insolvencies accelerate past the 300 mark', November 26, 2013.

${ }^{15}$ Clarksons Platou, Market Report, July 2015.
} 
rate indices, such as the ClarkSea Index. ${ }^{16}$ They use Principal Component Analysis (PCA) to extract common patterns across the different indices they construct. The resulting factor loadings indicate that the $\mathrm{KG}$ index exhibits peculiar risk-return characteristics. They argue that their constructed index constitutes a new measurement of the development of the market value of equity and distributions in the form of a performance index and incorporates specific information that is of primary importance for one-ship companies. In another study, Simic et al. (2016) investigate the valuation efficiency of the secondary market for the German KG ship funds. To this end, they examine whether the asset value of shipping funds is derived mainly from the market value of the KG equity traded in the secondary market and the book value of debt. The authors utilize a sample of 341 transactions of container shipping funds executed during the period 2007-2012. The results show that variations in the value of shipping fund can be explained by the ship values derived from the market of second-hand ships, the value of their time-charter contracts and the value of the option to extend the time-charter contracts.

Overall, the literature devoted on ship funds as an alternative source of capital is relatively thin. An interesting and underexplored research avenue in this area would be to examine whether the use of shipping funds as a source of capital exerts a positive influence on shipping companies' financial performance. Future research in the area should also investigate the impact of regulatory changes in shipping funds' performance. Specifically, the new German Capital Investment Act (Kapitalanlagegesetzbuch - KAGB), which came into force in July 2013, sets rules for improving the financial status and the management quality of KG funds. Strict regulations are likely to prevent KG companies from launching new funds and hamper private investor participation in the market. In addition, the clause that a single KG fund should invest in multiple types of assets, such as vessels, real estate, and/or aircraft, for risk diversification purposes is expected to fundamentally transform the structure and characteristics of these funds which in turn may have an impact on their performance.

\subsection{Other Financing Sources}

This section reviews the existing research focusing on alternative sources of shipping finance. Special financing schemes for the shipping industry trace back to the time when commercial shipping originated; since the Bottomry in the Code of Hammurabi in 1792 BCE. ${ }^{17}$ During the era of rapid industrialisation in the second half of the $20^{\text {th }}$ century, major shipbuilding countries in East Asia (Japan, South Korea and China) indirectly subsidized their shipbuilding industry by offering loans to shipowners at competitive interest rates, mainly through Export Credit Agencies (ECAs). As traditional bank lending became scarce post-2008, the role of such alternative ship financing sources became instrumental. For example, state-backed financing typically entails governments of shipbuilding countries providing incentives to place newbuilding orders to their domestic shipyards, giving rise to shipbuilding credit (Stopford, 2009).

\footnotetext{
${ }^{16}$ The ClarkSea Index is a weighted average index of earnings for the main vessel types, where the weighting is based on the number of vessels in each fleet sector.

${ }^{17}$ Bottomry in the maritime jargon is the keel of a vessel. It is a legal arrangement under which a shipowner borrows money from underwriters and distributes a pre-specified amount of money after the ship's safe return. If the voyage is not successful due to force majeure, the shipowner is exempted from repayment. In this regard, this form of financing is regarded as the origin of both bank mortgages and insurances.
} 
Although the contribution of ECA financing was quite limited during the pre-crisis period when bank loans were more easily accessible at attractive leverage and pricing terms, there has recently been growing interest among the shipping industry in such government-backed schemes (see Alexopoulos and Stratis, 2016). At the same time, ECAs - mostly based in China, South Korea, and Japan - are willing to expand their lending to shipping companies in an effort to support the domestic shipbuilding industry which is considered a major driver of their export-driven economies. ${ }^{18}$ Considering that ECAs are playing an increasingly important role in shipping finance they are directly affecting the shipbuilding and the shipowning businesses. Their importance is expected to become more significant, given the increased regulatory environment in shipping and governments' efforts to promote their shipbuilding industries and exports. As a result, future research should focus on analysing ECA's lending policies, their lending parameters (which are governed by OECD rules) as well as the credit criteria and credit scoring/rating models that are employed by these institutions in the lending practice.

Pires et al. (2005) examine the economic significance of the Merchant Marine Fund, a subsidy scheme for Brazilian shipping and shipbuilding companies. The analysis shows that the effectiveness of the ship financing system in reducing capital costs of Brazilian shipping companies is not significant. In another study, Yolland (1979) discusses the use of Eurodollars as a potential funding source for shipping companies amid the depressed market conditions in mid-1970s. ${ }^{19}$ Considering the fact that shipping freight rates are paid primarily in U.S. dollars, the author argues that the Euro-market can be a favourable financing source for shipping companies seeking to reduce their exposure to foreign exchange risk.

Ship leasing is another source of shipping finance with unique characteristics. In general, leasing has been extensively utilised by financially constrained shipowners in the form of Sale \& Leaseback agreements. Under such an agreement, the vessel is sold to a SPC controlled by a new owner (the lessor) and is at the same time chartered-back - under a long-term bareboat or timecharter agreement - by the shipowner who originally sold it (the lessee). In this way, the original shipowner cashes in around $80-90 \%$ of the vessel's Fair Market Value (FMV), while retaining its operation under the lease agreement. ${ }^{20} \mathrm{~A}$ study by Li (2006) discusses the pros and cons of ship leasing. The author argues that ship leasing can allot shipping business risk equally among the partaking sides. In addition, lessors can benefit from tax redemptions, retaining the company's working capital and longer repayment structures relative to other funding sources. Furthermore, retaining the working capital is possible since the lessee shipping company is not required to make a capital outlay for acquiring a vessel.

\footnotetext{
${ }^{18}$ Specifically, the lending portfolio of Bank of China shoot up from USD 12 billion in 2012 to USD 21 billion in 2015.

${ }^{19}$ Eurodollars are defined as dollar-denominated deposits at banks outside the U.S.

${ }^{20}$ Under a finance lease a purchase obligation exists after the bareboat charter (or time-charter) agreement expires and the lease is treated as an on-balance sheet item. In contrast, under an operating lease agreement, there is not a purchase obligation and the lease is treated as an off-balance sheet item. The popularity of both operating and finance leases in shipping became more prevalent after the onset of the financial crisis in 2008 as an alternative source of finance, especially so in China (according to Marine Money).
} 
PE funds comprise another important (alternative) shipping financing source, despite being largely untapped in the shipping finance area prior to 2008. Since then, however, PE companies have played an active role in providing funding required by shipping companies, especially when traditional bank financing became scarce. During the period 2007-2017, PE accounted for about $3.6 \%$ of financing of shipping companies, with a peak in 2013 of USD 7.5 billion (see Figure 2). The relatively recent surge of PE interest in shipping investment is largely driven by the deadlock in bank lending coupled with the historically low valuations of shipping assets during the post-crisis period. Despite its economic importance, there is no research that has not provided insight into the impact of PE investment in shipping. Only Abdullah et al. (2016) propose a conceptual framework for the use of Islamic PE in shipping. The authors argue that Islamic PE can be attractive to retail and institutional investors to promote and develop the shipping market in Malaysia, as the investigated country.

Given the significant investments by private equity in shipping during the last decade, the economic effects of PE participation as well as the performance of these investments are two interesting areas for further research. First, future research should concentrate on assessing the relationship between the different forms and degrees of PE participation and financial performance in the shipping industry. In general, investments of PE companies in the shipping industry can be segregated in: (i) acquisition of equity, (ii) bridge or mezzanine finance, (iii) purchase of debt, (iv) sale-leaseback transactions, and (v) formation of joint ventures. ${ }^{21}$ The impact of PE participation on different company performance metrics, such stock returns, profitability, and ultimately, company value as well as the demand-supply balance and asset valuations deserve further empirical investigation. Second, given that the majority of PE driven investments in shipping were carried out post-2008 when the value of maritime assets was at a historical low, it is also worth investigating to what extent PE funds failed to generate gains for their own investors, as has been frequently highlighted by the press. The extant literature on the performance of PE funds point to great deal of variations in fund performance (e.g. Kaplan and Schoar, 2005; Phalippou and Gottschalg, 2009). A question relevant to the shipping industry, with significant implications for the future of ship finance with respect to sources of capital, is whether, in general, PE investment in shipping offers an attractive risk-return profile for investors.

\subsection{Capital Structure of Shipping Companies}

A firm's capital structure is derived by the balance of different funding sources utilised to finance its assets. Financing choices may affect a firm's value in the presence of taxes and market frictions such as financial distress costs and information asymmetry, making the capital structure choice a key financial management decision. Since the seminal work of Modigliani and Miller (1958) three major competing theories have been offered in the finance literature to explain the drivers of corporate capital structure; the trade-off theory (Kraus and Litzenberger, 1973), the pecking order theory (Myers and Majluf, 1984) and the market timing theory (Baker and Wurgler, 2002). ${ }^{22}$ Yet, existing research has not reached a unanimous consensus on a single

\footnotetext{
${ }^{21}$ UNCTAD, Review of Maritime Transport 2013.

${ }^{22}$ The trade-off theory posits that the optimal capital structure balances between the benefits and costs of debt. In contrast, the pecking order theory implies that there is no optimal capital structure. Instead, companies should follow
} 
theory that can explain corporate financing decisions, but rather, that capital structure is timevarying and shaped by company-specific and industry-specific factors (see Lemmon et al., 2008; Graham and Leary, 2011).

A number of factors, some of which have already been discussed earlier in the paper, make the financing mix choice particularly important for shipping businesses. First, shipping investments in newbuilding and second-hand vessels require significant fund raising, rendering the sector highly capital intensive. Second, the sector's excessive reliance on traditional debt financing and the relatively recent trend towards further diversification of funding sources. Third, the fact that shipping companies enjoy industry-specific tax incentives in most countries, which renders the benefit from a tax shield trivial (Drobetz et al., 2013). Fourth, the sector is subject to heightened indirect costs of financial distress in the form of opportunity costs when prevented from buying cheap assets in a financial distress situation. Despite some of the above factors, diluting the benefits of debt, shipping companies exhibit capital structures heavily tilted towards debt. Accordingly, Drobetz et al. (2013) report that the average leverage ratio for a sample of 115 globally listed companies is $41 \%$, relative to $25 \%$ for a sample of companies across different industries in $\mathrm{G} 7$ countries. The high leverage ratios observed can be attributed to the high degree of asset tangibility, the family-oriented nature of many shipping businesses with closely held ownership structures as well as the riskiness and cyclicality in cash flows, which can deter equity investors. ${ }^{23}$ Drobetz et al. (2013) also show that shipping companies' speed of adjustment to a target leverage ratio is higher than in other industrial companies which they attribute to the substantial expected costs of financial distress induced by deviations from target ratios. ${ }^{24}$ Grammenos and Papapostolou (2012a) argue that the capital structure of shipping companies during 2000s is best explained by the market timing theory and by the pecking order theory during the 1990s. The authors argue that the increase in the number of shipping IPOs and the issuance of public debt in 2000s is consistent with the theoretical predictions of the market timing theory. Drobetz et al. (2013) examine 115 listed shipping companies around the world during the period 1992-2010 do not find strong evidence in support of the market timing theory.

With regards to the drivers of capital structure choice, Merika et al. (2015) examine 117 shipping publicly listed shipping companies, during different phases of the business cycle and find that size, asset tangibility, and corporate performance are significant financing choice determinants. ${ }^{25}$

\footnotetext{
a certain financing hierarchy contingent on the cost of each source of capital. Thus, they should first utilise internal financing where available, followed by debt financing, with equity being raised only as a last resort. Finally, the market timing theory broadly argues that a company's capital structure should be driven by the extent to which its equity is mis-valued by the market. Thus, a company's capital structure is essentially determined by its past markettiming behaviour and not driven by an optimal financing mix.

${ }^{23}$ Drobetz et al. (2014) study of impact of corporate social responsibility (CSR) disclosure on the financial performance of shipping companies and, among others, report a negative relationship between financial leverage and CSR disclosure.

${ }^{24}$ Nam and An (2017) document a positive relationship between default risk as measured by Altman's K-Score (where a higher score means lower default risk) and financial performance proxied for by Return on Assets (ROA) for a sample of Korean shipping and logistics companies during the period 2003-2012.

${ }^{25}$ In the shipbuilding specturm, Adland et al. (2017c) examine capital structure drivers for globally listed shipbuilding companies and find size, asset risk and the market-to-book ratio to be significant and that shipbuilders tend to adjust their capital structures more rapidly than other industries (such as, airlines, shipping companies and real estate).
} 
Negative relationships are reported between leverage and profitability and leverage and concentrated ownership during all phases of the business cycle, apart from the peak period of 2007. Drobetz et al. (2016a) investigate the impact of unexpected cash-flow changes on the investment and financing decisions of shipping companies during different market conditions. They find that, due to the high volatility in operating cash-flows and asset values, the financing behaviour of shipping companies is more sensitive to adverse cash-flow effects relative to companies operating in other industries. In addition, while financially healthy companies are able to increase their long-term debt even post-2008, financially weak companies cannot raise sufficient funds regardless of the prevailing economic conditions. The authors also examine the impact of financial flexibility measured by excess cash holdings and document that financially weak companies retain higher cash reserves during "non-crisis" periods in order to offset potential cash flow shortages during "crisis" periods. Del Gaudio (2018) investigates the capital structure of 500 Italian shipping companies during the period 2007-2015. Italian companies are found to be highly debt-dependent, with the average leverage ratio (debt-to-assets) of $70 \%$ while bank credit is a major funding source (81.8\%). Cash holdings comprise another component of a company's capital structure. Accordingly, Ahrenda et al. (2018) investigate the cash holdings of 144 shipping companies in 33 countries during 1983-2014. They report that the cash holding ratio (cash and short-term investments divided by total assets) is $12.6 \%$ compared to that of matched manufacturing peers of $7.3 \%$. The higher cash holding of shipping companies is attributed to the higher marginal value of cash, measured by the impact of additional cash on the company's excess stock return. The authors argue that the relatively higher level of cash holdings of shipping companies is consistent with the precautionary motive that cash provides additional financial flexibility.

Table 5 summarises the existing evidence on the sources finance as well as the determinants of capital structure in the shipping industry. Yet, a number of avenues on the capital structure of shipping companies remain unexplored. First, the agency benefits of debt (Jensen 1986), reducing the free cash flow, thus imposing discipline among top executives and reducing misbehaviour and frivolous investment decisions is well documented. A study by Goedhart et al. (2006) shows that this benefit, although less direct, is quite significant as a capital structure driver, and argues that the balancing act between financial flexibility and fiscal discipline is a very important consideration in the financing choice. Considering the predominance of debt in shipping capital structures, the effect of financial discipline and its impact on attracting investors deserves further investigation. Second, survey-based evidence on the perception of important capital structure drivers has proved instrumental in capital structure research (see Graham and Harvey, 2002). Such evidence from the shipping industry would provide fundamental insights in how shipping CFOs make financing choices. Third, the link between capital structure and firm value in the shipping industry remains unclear. There is anecdotal evidence that companies making more effective use of financial leverage carry higher valuations. The extent to which this holds true among shipping companies is an interesting research question, especially because of the positive effect of tax in this case is negligible 


\section{Shipping Investment and Valuation}

This section focuses on the drivers of shipping investments, along with the most common valuation methods (capital budgeting) employed within the shipping paradigm. One of the instrumental factors determining the success of a company is the economic growth and value creation it achieves through internal investment (CAPEX) and inorganic growth (Mergers and Acquisitions). Investment decisions are of critical importance to the value of a business, and especially so in the shipping industry given the large amounts of capital required and the excess volatility in service rates and asset values. To this end, this section provides an overview of existing research on the key considerations and factors that affect shipping investment decisions, the various investment valuation methods employed, the cost of capital of shipping investments, the risk-return trade-off in different market segments, as well as, the value creation potential of inorganic investment decisions in the shipping industry.

\subsection{Key Drivers of Shipping Investment Decisions}

A company's value is conditional on the combined value of the assets it holds. Equally, the value of a shipowning company can be derived by taking the present value of the vessels in its fleet. The primary scope of the investment appraisal process within the maritime framework is to reach value enhancing investment decisions based on the interactions among key industry factors, such as: freight rates, newbuilding and scrapping volumes, demand for shipping services, newbuilding and second-hand vessel prices, ship-building costs, bunker fuel prices, among others (see Strandenes, 1984; Beenstock, 1985). Accordingly, a large part of the literature has focused on the drivers of shipping investment decisions.

In an attempt to explain shipping investors' behaviour, Berg-Andreassen (1990) introduced an investment decision-making stochastic model for the dry bulk and tanker sectors based on shipowners' risk appetite. According to this model, shipowners can be classified in two groups of investment behaviour: "risk averters" and "risk lovers". The author argues that "risk lovers" adjust their fleet capacity toward a long-term mean regardless of the prevailing shipping market conditions; while "risk seekers" expand their fleet capacity during volatile freight markets. In another study, Goulielmos and Psifia (2006a; 2006b) analyse monthly trip-charter and timecharter rates during the period 1971-2002, and report that freight rates exhibit long-term persistence (memory). The authors argue that the identified long-term persistence should be taken into account by both shipowners and shipping bankers when making investment and financing decisions. Adland and Koekebakker (2007) use a non-parametric cross-sectional data Multivariate Density Estimation (MDE) on actual Sale \& Purchase transactions in the dry bulk second-hand vessel market, allowing for non-linearity. Empirical results, over the 1993 to 2003 period, indicate that the second-hand vessel value is a partial non-linear function to deadweight, vessel age, and freight market conditions. In another study, Alizadeh and Nomikos (2007) use the long-term equilibrium (cointegrating) relationship between second-hand vessel prices and time-charter earnings (Price to Earnings ratio) to test the profitability of trading rules for secondhand vessels. The results reported show that the deviations of the Price-Earnings ratio from its long-run mean could be used as an indicator of investment timing in the second-hand vessel market. Merikas et al. (2008) explore whether the ratio of second-hand/newbuilding prices can be used as an indicator for making a choice between purchasing a second-hand tanker vessel or 
ordering a newbuilding one. The authors also provide empirical evidence that the movement of this ratio - and hence ultimately the decision between a second-hand or a newbuilding vessel depends on the shipping market's cyclicality and the expectations its participants. In a more recent study, Bulut et al. (2013) examine dry bulk market entry decisions and asset allocation in terms of business cycles. They investigate a number of indicators capturing the investment climate in the shipping business and argue that shipping investors typically place newbuilding orders during vessel price peaks, leading to a long-term decline in ROE.

In a study on shipping investments determinants, $\mathrm{Xu}$ and Yip (2012) examine annual newbuilding contracts in 15 major shipbuilding countries during the period 1996-2008. Their results indicate that spot freight rates, existing fleet size (i.e. shipping supply) and world trade volume (i.e. shipping demand) are key drivers for shipowners' contracting decisions. Their results highlight the instrumental role of shipowners' (over)confidence when making newbuilding investment decisions. In another study, Adland and Jia (2015) introduce an alternative dimension when exploring shipping investments. Specifically, the authors suggest that newbuilding prices are not comparable over time because the parameters of the newbuilding contracts vary themselves, i.e. the delivery lag and payment schedules agreed. To take this feature into account, the authors derive an equation for the contemporaneous equilibrium prices across the newbuilding, second-hand, demolition and freight markets. Results show that the low volatility observed in the newbuilding market relative to the second-hand market is justified by the presence of a "term structure of newbuilding prices", as the parameters of the newbuilding contracts vary over time.

The excess volatilities in vessel prices and freight rates have also been attributed to the "time-tobuild" effect, which largely determines shipping investment decisions. Specifically, freight market conditions and their outlook are likely to change considerably during the period a vessel is being built - typically a period of 18 to 36 months. Early research by Miyashita (1982), divides the investment planning process in the dry bulk segment, during the period 1963-1976, into two stages: first, the industry discounts by two to three quarters (using the technical renovations factor) the transport service sales volume capacity, and its growth rate, before committing to shipbuilding contracts. Second, in the next quarter the final investment plan is decided after taking into consideration the marginal capital efficiency and the broken-up tonnage. More recently, Kalouptsidi (2014) explores the nature of fluctuations in the dry bulk industry by quantifying the impact of time-to-build and demand uncertainty on shipping investments and vessel prices. Specifically, the author provides evidence that the construction lag for a newbuilding vessel is a combination of adjustment costs and uncertainty in the shipping investment process. ${ }^{26}$ The results also show that shipping investment activity is more volatile as the "time-to-build" period declines, implying that shipowners respond to economic conditions more rapidly as the construction lag for a newbuilding vessel reduces. Exploring the feature of delivery lags in shipping, Adland et al. (2006) investigate the equilibrium relationship in the dry bulk market between second-hand prices, newbuilding prices and freight rates. The methodology adopted accounts for the existence of a time-varying delivery lag. The results indicate that the

\footnotetext{
${ }^{26}$ Shipping companies are unlikely to be able to adjust their fleet capacity to an increase in demand for shipping services during the vessel construction lag.
} 
second-hand market is co-integrated with the freight and newbuilding markets while the cointegrating relationships identified can be utilized as investment guides.

Finally, some studies have focused on the development of trading rules to exploit any profit opportunities in the shipping markets, thereby testing the validity of the Efficient Market Hypothesis (EMH). For example, Adland and Koekebakker (2004) focus on the development of profitable investment rules in the vessel markets and explore the profitability of technical analysis rules (filter rules, moving averages, and support and resistance levels) for purchasing and selling second-hand vessels in the dry bulk segment. Their results indicate that trading rules are not capable of generating excess profits over the buy-and-hold benchmark when taking into account the existence of transaction costs and vessel price slippage. These results are in favour of the EMH in the dry bulk second-hand market. However, empirical evidence in Chou and Chen (2018) show that investment rules based on Bollinger bands are able to outperform the benchmark buy-and-hold strategy for the Capesize and Handysize vessels.

An important limitation of several studies exploring the determinants of shipping investments is the fact that they do not take into account the potential existence of endogeneity among the variables of interest. For example, the value of a vessel and subsequently the decision for a shipping investment might be simultaneously determined with other key shipping-related variables, such as the prevailing freight rates, bunker costs, etc., thus rendering the cause and effect relationship between the variables dubious. For this reason, studies in the area should aim to deal with potential endogeneity effects affecting the relationships they examine.

Although existing research has identified and examined a number of shipping investment determinants, the literature on how shipping companies make investment decisions as well as the evaluation of such decisions remains thin. One area that has attracted researchers' attention in the area of corporate finance is the impact of under-(over)-investment on company value. For instance, Richardson et al. (2006) employ a measure of total investment efficiency capturing corporate investment that diverges from its expected level, given a set of factors that have been shown to predict the optimal investment level. This investment efficiency metric captures both internal and inorganic investment and could provide insights on how optimally (and under what conditions) shipping companies allocate funds for investment purposes, as well as, to what extent a more efficient investment strategy leads to superior performance. Given the capital/investment intensive nature of the shipping industry future research should also explore this avenue further.

\subsubsection{Behavioural biases and shipping investments}

A strand of research has attempted to explain shipping investments on the basis of heuristics related to human behaviour, such as risk attitudes, market sentiment, intuition and gut feeling. While heuristics-induced decision-making enables shipowners to respond quickly to the shortlived investment opportunities in the shipping markets, such behaviour may also lead to systematic errors or cognitive biases under certain conditions (Gigerenzer, 1991), which can be reflected in the rather unpredictable and relatively frequent shipping market collapses. Accordingly, shipping market crises have been largely attributed to false expectations regarding 
market's consensus and/or the existence of herding behaviour among shipping market players, which tend to lead to biased investment decision-making in newbuilding orders (Scarsi, 2007).

Greenwood and Hanson (2015) study the link between investment boom and bust cycles and return on capital in dry bulk shipping. The authors examine a dataset of monthly second-hand vessel prices and time-charter rates over the period 1976-2011 and document that high vessel earnings are associated with high second-hand vessel prices and a higher orderbook for new vessels, but lower future returns. This result is attributed to behavioural characteristics of shipping market players (shipowners). Specifically, the authors develop a model where companies over-extrapolate exogenous demand shocks for the shipping service and partially neglect the endogenous investment response of the rest of the shipowners (their competitors). Consequently, shipping firms overpay for vessels and overinvest during booms, while they realize poor subsequent returns. This investment behaviour can result in dramatic excess volatilities in vessel prices. In a related study, Papapostolou et al. (2014) develop a sentiment index for the dry-bulk market. Specifically, the authors show that market sentiment can serve as a contrarian predictor of future vessel prices in the dry bulk segment. One step further, Alizadeh et al. (2017) investigate the impact of speculative investment behaviour emanating from heterogeneous beliefs on the volatility of second-hand dry-bulk vessel prices during the period 1991-2016. The authors report that momentum strategies perform better than contrarian (buyand-hold) strategies, and also that a higher degree of momentum (contrarian) investors' participation can lead to an increase (decrease) in the volatility of second-hand vessel prices.

Focusing on the herding behaviour of shipping investors, Papapostolou et al. (2017) explore the impact of shipowners' behaviour in shipping investments by quantifying unintentional and intentional herding. ${ }^{27}$ The authors analyse data on newbuilding and scrap tonnage for the period 1996-2015 and report that ordering and scrapping decisions are largely the result of unintentional herding. This result implies that shipowners' herding behaviour is due to their common characteristics (e.g. their analytical skills, academic background, etc.) leading to similar investment decisions among them.

\subsection{Investment Valuation Methods}

The empirical evidence reviewed in the previous section suggests that shipping investment decisions tend to be driven by a multitude of factors, which renders shipping investment valuation a particularly challenging task. This section reviews the literature on the most commonly employed shipping valuation approaches. The investment appraisal process deals with estimating a project's future cash-flows by taking into account their degree of uncertainty and is typically utilised as a tool to make capital budgeting decisions and facilitate company value maximisation (Peterson and Fabozzi, 2002). The Net Present Value (NPV), the Internal Rate of Return (IRR) and the Accounting Rate of Return (ARR) are the most widely utilised approaches in investment appraisal while industry professionals often rely on a set of investment

\footnotetext{
${ }^{27}$ While intentional herding indicates behaviours of less informed or less established investors mimicking reputable peers, unintentional herding indicates co-movement of investors driven by similar market fundamentals and characteristics.
} 
appraisal methods as part of their financial management decision making process (for a comparison see, Graham and Harvey, 2001; Alkaraan and Northcott, 2006).

Evans (1984), Goss (1987) and Albertijn et al. (2011; 2016) present examples of how investment appraisal techniques (NPV and IRR) can be utilised by shipping companies. Cullinane and Panayides (2000) survey 65 UK-based shipping companies and report that the IRR is the most commonly employed investment valuation method - possibly due to its simplicity - followed by the NPV and the Payback Period approaches. The authors conclude that a systematic approach to capital budgeting is absent among a number of shipowners and operators. However, shipping companies do not appear to adopt a uniform approach towards capital budgeting, which can be attributed to the complexity of shipping operation that renders intuitive conceptualisation, experience or even the application of capital budgeting methods such as NPV and IRR not enough for aiding managerial decision making. Instead, business decisions should be grounded on the development of an analytic, structured and systematic framework for capital budgeting.

Despite the popularity of investment appraisal techniques based on Discounted Cash-Flows (DCF), such as the NPV and IRR, they are subject to important limitations. ${ }^{28}$ To tackle these drawbacks, alternative investment appraisal techniques have been introduced in the shipping finance literature such as Multi-Criteria Decision-Making (MCDM) and Real Options Analysis (ROA).

The popularity of MCDM methods within operations research and management science, which can be broadly defined as decision-making optimisation processes employing multiple criteria, has grown significantly over the last two decades. Like in financial decision-making problems, it may well be appropriate to pursue a multiple objective approach to shipping investment decisions in shipping. Along these lines, Rousos and Lee (2012) propose a form of MCDM, the so-called Analytic Hierarchy Process (AHP), in which shipping investment appraisal in dry bulk shipping is treated as a multi-criteria optimisation problem. The model proposed generates an optimal trade-off between the results from traditional valuation methods, the project's risk profile and psychological factors in decision maker's psychology, among other parameters and offers an alternative angle on the investment evaluation problem in shipping. Along these lines, Clintworth et al. (2017) employ a AHP-based MCDM approach for fleet expansion project financed by the European Investment Bank (EIB). Their model takes into account financial (NPV, IRR and Economic Rate of Return - ERR) and non-financial criteria (such as coastal and environmental protection, as well as regulatory constraints, such as ballast water treatment systems or emission control areas) while controlling for the inherent subjectivity inherent in investment decision making.

Another dimension in shipping valuation is the optionality in shipping investments. ROA applies financial option valuation models in order to assess the value of optionality in shipping

\footnotetext{
${ }^{28}$ First, DCF valuation is sensitive to assumptions related to a number of inputs (for instance future cash-flows, growth rates and discount rates) that are challenging to project with certainty. Second, the DCF method doesn't take into account non-purely-financial factors, such as behavioural effects or managerial flexibility in tackling business contingencies. Third, previous literature points to a misuse of DCF methods. For example, a less rational top management team may regard the DCF as a set of checks (Lai and Trigeorgis, 1995) or can utilize it to justify already-made investment decisions (Bendall and Manger, 1991).
} 
investments. It is typically used as an investment tool to compute the value of options embedded in investment projects which should be taken into account in the overall project's appraisal. Real options capture the value of flexibility with regards to the project's size (for example, expanding or contracting) and its timing (for example, deferring or abandoning).

The pricing models in real option valuation can be classified in three broad categories: closedform solutions, dynamic programming and simulations. However, the extant literature applying ROA for shipping investments mainly utilize the closed-form solutions and dynamic programming approaches. In order to derive a closed-form solution for ROA, it is essential to identify the stochastic properties of the cash-flows pertaining to a shipping investment. To this end, Bjerksund and Ekern (1995) conjecture that cash-flows in shipping are characterised by a mean-reverting Ornstein-Uhlenbeck process, implying that freight rates follow a normal distribution and gradually revert to a constant mean following a shock. Based on these assumptions the authors derive a closed-form solution for the valuation of a time-charter contract. In a similar study, Jørgensen and De Giovanni (2010) introduce a closed-form solution for the valuation of a Time-Charter contract with Purchasing Options (TC-POP) which can be exercised only at the option's expiration date - same as a European option. In addition, Sødal et al. (2008) advocates a closed-form solution for valuing the embedded option to switch a combination carrier that can be deployed both in the dry bulk and the tanker segments. Another study that provides a closed-form solution for the valuation of options in shipping investments is the one by Tvedt (1997). The author suggests that the valuation of a VLCC reflecting the options of layup and scrapping can be approximated using a geometric mean reversion process. Finally, Bendall and Stent $(2003 ; 2005$; 2007) adopt the dynamic programming approach under a ROA framework to assess the value of the options embedded in liner shipping investment projects. Such options include: fleet expansion/replacement, service network development and strategic flexibility.

Another strand in the literature of real options valuation in shipping deals with the option to switch to different shipping segments and sub-segments. For example, Sødal et al. (2009) test decision rules based on a ROA valuation model of freight rates in the second-hand vessel market. Specifically, a dry bulk vessel is switched with a tanker vessel when the expected NPV of the switch is optimal from a ROA-based rule. Results indicate that over the 1993 to 2005 period switching generally did not pay off, pointing to the efficiency of the dry bulk second-hand market. In a related study, Adland et al. (2017b) employ a ROA model with a stochastic freight rate differential to estimate optimal triggers for an Aframax-type tanker vessel to switch between "clean" (refined) oil products and "dirty" oil products (crude oil and heavy fuel oil) and gauge the value of the switching option. The authors argue that the value of the switching option has increased over time and is higher that the investment premium associated with buying such a vessel.

Another important feature when operating a vessel is the duration of the freight contract under which it is chartered and the commitments this contract entails. The choice of the freight contract introduces further options/scenarios that need to be valued under the ROA framework and to be incorporated in investment appraisal. In an analysis on the relationship between tanker newbuilding orders and time-charter rates using an ROA framework, Dikos and Thomakos (2012) 
find that tanker owners systematically account for the value of the option to wait in their investment decision. In a related study, Axarloglou et al. (2013) utilise a real options framework to investigate the determinants of the time-varying spread between spot (voyage) and timecharter rates. They argue that the time-varying spread is directly related to the shipping business cycle, to demand expectations, and to market volatility, and that also the spread is the result of the strategic decision to commit vessels for a short period (long period) of time during a market upturn (downturn) and thus maintain flexibility (commitment). ${ }^{29}$

Several other studies adopt the ROA framework to value specific operating/financing options embedded in shipping investments and across the different segments and sub-segments of the shipping markets. For example, Kyriakou et al. (2017b) propose a ROA model for investments valuation and timing in the dry bulk segment based on the exponential mean-reverting property of freight rates. Rau and Spinler (2016) propose a ROA for optimal investment decisions in liner shipping under the assumption of oligopolistic competition. They find that the number of market participants and the intensity of competition affect optimal capacity, company values and investments. Focusing on the container market and adopting a Markov process, Balliauw (2017) uses a real options model, to analyse the buy (entry) and sell (exit) decision of shipowners. Finally, focusing on the LNG markets, Acciaro (2014) investigates the optimal time for investment in LNG retrofit and takes specific account of the value of an investment deferral strategy when compared to the advantages emanating from the immediate exploitation of fuel price differentials. By adopting ROA, the author shows that there is a trade-off between low fuel prices and capital expenses for investment in LNG retrofit.

While investment valuation in the shipping industry may be seen as a complex task given the idiosyncratic characteristics of sector, existing research has gone a long way quantifying value driving factors and deriving criteria for investment decision-making. A summary of existing literature on alternative valuation methods is presented in Table 6. One research area that existing literature should focus more in the future is that of relative market valuation which derives an underlying value for an investment relative to the market/traded value of other similar assets. Albertijn et al. (2016) provide an overview of such market-based valuation methods, but their effectiveness (relative to other valuation methods) and sensitivity to the choice of market comparables deserve further investigation. Shipping business valuation is another interesting research avenue. Alexandridis and Singh (2016) offer a summary of the main income, market and asset-based approaches used in shipping company valuation but further evidence on their relevance under different business valuation scenarios in different shipping segments along with their sensitivity on the assumptions employed would offer valuable insights in the area of shipping valuation.

\subsection{Cost of Capital and Sources of Risk in Shipping Investments}

One of the instrumental inputs in investment valuation is the cost of capital. In DCF valuation for instance the expected cash-flows during a project's life - which effectively determine the value of an investment - are discounted by the cost of capital (or required rate of return) in order

${ }^{29}$ For evidence of ROA in port terminal investments see Zheng and Negenborn (2017). 
to adjust for their riskiness. The cost of capital is also relevant in alternative valuation methods discussed in section 4.2 such as for instance when valuing financial flexibility in ROA, while it also comprises one of the assessment criteria in MCDM. Given the capital-intensiveness and the long horizon (typically, more than 15-20 years) of shipping investments, the estimation of the cost of capital is of paramount importance in the investment decision-making process. The Weighted Average of Cost of Capital (WACC), which weights the required return for each source of capital proportionately, is by and large the most commonly used by corporate financiers (McLaney et al., 2004). However, a common issue with WACC arises from estimating the cost of individual funding sources, especially the cost of equity since it requires a great deal of assumptions and forecasts for a number of inputs (e.g. future equity risk premium and riskiness of the business). Much of the general finance literature concentrates on asset pricing models and the identification of underlying risk factors which can also be used in the estimation of the cost of capital. From the Capital Asset Pricing Model - CAPM (Sharpe, 1964; Lintner, 1965; Mossin, 1966) to CAPM variants (Black, 1972; Merton, 1973) and multi-factor models (Ross, 1976; Fama and French, 1992) these models aim to capture the relationship between risk and return.

Survey evidence suggests that financiers typically use the CAPM to derive the cost of equity (a key input for WACC) in NPV investment appraisal (Graham and Harvey, 2001; McLaney et al., 2004). At the heart of CAPM lies the estimation of the asset beta, which is the sensitivity of an asset's return to market movements (risk). A beta with value higher (lower) than one indicates that the asset in question has a higher (lower) risk/sensitivity relative to the market. Early studies by Kavussanos and Marcoulis (1997a; 1997b; 2000a; 2000b, 2001), estimate stock betas for U.S. shipping companies and report that these are significantly lower than unity (carry lower risk than the market average) during the period 1985-1995. Moreover, Kavussanos and Marcoulis (1998) estimate and compare stock betas of U.S. shipping companies with those in other transport modes (air, rail, truck) and industries (electricity, gas, petrol, real estate) during the period 1984-1995. The authors argue that shipping is the only transportation sector which exhibits betas well below unity, while the betas of air, rail and truck sectors are not statistically different from one. The authors report that the results are sub-period specific. For instance, the first part of the 1990's, water transportation company risk was more related to company specific factors, and as a result more easily diversifiable, than in the second part of the 1980's. Similar studies by Kavussanos et al. (2003) and Drobetz et al. (2016b) report that the betas of globally listed shipping companies are significantly lower than one during the periods 1996-1999 and 1973-2014, respectively. The empirical evidence that betas of shipping stocks are on average lower than (or at most equal to) one is in stark contrast to the general perception on the riskiness of the shipping industry, indicating that there is little relation between the shipping stocks and the world economy due to the considerable lag associated with the delivery of new tonnage.

Existing literature has also examined the characteristics of stock betas within shipping subsectors, during different phases of the shipping business cycle, relative to other industries. Along these lines, Kavussanos et al. (2003) find that shipping stock betas vary among the different segments of the shipping industry. While shipping stock betas in the ferry, tanker, dry bulk and container segments are significantly lower than the betas of market indices, those in the drilling segment are significantly higher than one, and those in the cruise, offshore and "diversified" segments, i.e. including both shipping and non-shipping lines of business, are not different from 
one. In a related study, Kuo et al. (2016) investigate the freight risk-return relation in the dry bulk sub-sector measured by asset beta. They document that this relation varies depending on vessel sub-segment, and that it has shifted from high-risk/high-return to high-risk/low-return for Capesize vessels.

Other research investigates the time varying properties of shipping stock betas. For example, Tezuka et al. (2012) report that betas of listed Japanese liner shipping companies during the period 1980-2006 are positively associated with the degree of shipping market competition due to the associated regulatory changes - and negatively related to the level of shipping market concentration. Further, Drobetz et al. (2016b) find that stock betas of shipping companies around the world during the period 1990-2013 fluctuate with shipping market conditions. They are also positively related to operating leverage, financial leverage, growth opportunities, default risk, freight rate volatility and the credit spread, and negatively related to corporate liquidity and industrial production growth.

The fact that that shipping stock betas tend to be lower (or at best not different) from market betas suggest that corresponding stock returns are also driven by unsystematic risk factors. Accordingly, a series of studies has focused on factors that explain shipping stock returns beyond betas. Kavussanos and Marcoulis (1997b; 2000b) report that the asset-to-equity (book value) ratio is negatively related to shipping stock returns in the U.S. during the period 1984-1995. Panayides et al. (2013) document the existence of an illiquidity risk premium using a sample of 76 U.S. listed shipping stocks during the period 1960-2009. Further, the study shows that the illiquidity risk of individual shipping stock returns is priced by the market over and above the market-wide illiquidity and/or other systematic risk factors. This points to a positive association between illiquidity, computed at the stock level, and shipping stock returns. In another study, Kavussanos and Marcoulis (2000a; 2000b) examine whether macro-economic factors are reflected in U.S. shipping stock returns and report that a positive relationship with oil prices and a negative with industrial production. In a more recent study, Drobetz et al. (2010) corroborate the pronounced impact of oil prices and industrial production on stock returns listed shipping companies around the world during the period 1999-2007.

The evidence on the factors driving shipping stock returns suggests that incorporating shipping as an asset class in a portfolio can result in diversification benefits yielding more efficient riskreturn trade-offs. Cullinane (1995) argues that a shipping diversification strategy may be seen as a portfolio optimisation problem. By applying the Markowitz optimization portfolio framework in the dry bulk market, the author reports that shipowners are able to effectively build optimal shipping portfolios, using different trade routes and types of charter contracts. Grelck et al. (2009) examine the impact on diversification when including shipping stocks in investment portfolios. They find that Sharpe ratio (the risk-adjusted investment performance) increases when a synthetic shipping index comprising of 41 equally-weighted shipping stocks is included in the existing combination of stock and bond indices.

Given the growing importance of shipping equity markets as a source of funding and the heightened volatility inherent in asset values and cash flows, risk measurement becomes fundamental for investment decisions. Asset allocation and risk-return attributes in the shipping 
equity market have been examined by Andriosopoulos et al. (2013) who employ evolutionary algorithmic approaches to derive investment strategies replicating the performance of equity and physical freight indices in a cost-effective way. In an effort to gain further understanding of shipping equity risk and its implications for asset allocation, Pouliasis et al. (2017) develop a comprehensive model to examine the dynamics of stock price volatility for different vessel segments. They investigate the role of the mixture distributions in predicting future volatility and assess the value of volatility and correlation timing in optimal portfolio selection. Results indicate that large losses are strongly correlated (financial contagion), associated with asymmetric transmission processes. The authors argue that the results can help improve the understanding of time-varying volatility, correlation and systemic risk of shipping stocks.

Overall, the literature devoted to the risk-return profile of shipping stocks offers important implications for both financiers of shipping companies and financial investors (see Table 7). Especially, the analysis of the impact of systematic and unsystematic risks on stock returns is of particular importance for equity and company valuation, portfolio diversification and risk management through hedging.

One area where future research on shipping valuation should concentrate is on the evolution of capital sources and sources of risk in the sector. Despite bank debt financing being the predominant source of funding in the shipping industry, recent trends discussed earlier in this paper suggest that ship financing has been subject to a structural shift whereby shipping firms currently rely more on both, equity and debt capital markets for their funding needs. This should have a material impact for companies' overall cost of capital and come with implications for shipping valuations. With ship-lending banks reducing their overall exposure to the shipping market - as a result of the post-2008 crisis and the ensuing stricter regulatory capital requirements - and equity investors becoming increasingly wary about the risks inherent in shipping equity investments and requiring higher rates of return, the impact of such developments in stock betas, the overall cost of capital and capital budgeting in shipping is a promising research subject.

\subsection{Shipping M\&As: Drivers and Value Creation}

As highlighted in the previous sections, organic (or internal) investment within shipowning companies entails mainly projects involving the purchase of new vessels. In more recent years, inorganic investment in the form of Mergers \& Acquisitions (M\&As) has gained pace becoming a fundamental source of growth for shipping companies. In the aftermath of the post-2008 crisis, market consolidation, across an industry that traditionally resisted it, has picked up significantly with the total value of shipping M\&As in 2015 being 31.86 billion, respectively, ahead of any other year since the financial crisis struck. ${ }^{30}$ Alexandridis and Singh (2016) argue that although the heightened deal activity in more recent years is driven by the low asset values and more pronounced financial distress, it is very likely that, given highly fragmented nature of the shipping industry, market consolidation is likely to persist. In view of the growing importance of inorganic investment in shipping this section reviews the existing research on its

\footnotetext{
${ }^{30}$ Tradewids, 'Shipping plays its part in record M\&A year' using data from Dealogic.
} 
characteristics and impact on company value, where existing literature has primarily concentrated.

A merger or acquisition can be broadly defined as the corporate activity of combining two or more companies into a new economic entity in pursuit of shared goals and/or synergistic gains. In the maritime spectrum, major shipping companies carry out M\&As for profit maximisation, enhancing market share, gaining control over the global supply chain and operational diversification (Heaver et al., 2000; Brooks and Ritchie, 2006). Moreover, the multi-national nature of many shipping corporations involves global supply chains, as well as, data synchronisation, scheduling, and operations among business partners located in different countries. Therefore, combining shipping and related transportation services (e.g. stevedoring, logistics, warehousing and other ancillary services) can offer a valuable competitive edge to shipping companies, such as expansion of geographical reach and control of a broader logistics chain, while facilitating enhancement of customer service. ${ }^{31}$

With regards to the M\&A drivers in the shipping industry Fusillo (2009) investigates 54 M\&A transactions in U.S. liner shipping consummated between 1993 and 2007 and argues that their drivers are consistent with the neo-classical merger theory postulating that M\&A activity is a process of natural adjustment to changes in economic environments or industrial shocks (Gort, 1969). The author postulates that liner shipping companies are more likely to become takeover targets since they are less likely to adjust their business operations in response to a new economic environment given their high fixed costs. ${ }^{32}$ Along these lines, a main finding in this study is that the heightened M\&A activity in the U.S. liner shipping industry in the late 1990s can be largely attributed to the introduction of the U.S. Ocean Shipping Reform Act (OSRA) in 1998 which technically undermined the roles of the conventional shipping conference system and collusive pricing. ${ }^{33}$ More specifically, the author argues that liner shipping companies that are faced with more intense competition, and consequently, increased freight rate earnings uncertainty pursue economies of scale through business consolidation as a process of adjustment to a new economic environment. In addition, Fusillo (2009) also report that M\&As in the U.S. liner shipping industry is positively associated with excess capacity and negatively related with the level of freight rates. This finding is in stark contrast with the evidence provided by Alexandridis and Singh (2016) pointing to a 50-60\% correlation between freight rates and global M\&A activity during 1990-2014. ${ }^{34}$

Other studies also focus on shipping M\&A motives. Syriopoulos and Theotokas (2007) and Merikas et al. (2011) provide evidence in support of the disciplinary motive for takeovers in the shipping industry, and in particular the poor management hypothesis (see Dietrich and Sorensen, 1984). The authors argue that in the case of Stelmar Shipping - a tanker shipping company that

\footnotetext{
${ }^{31}$ For a detailed overview of shipping M\&As process and motives, see Alexandridis and Singh (2016).

${ }^{32}$ Liner shipping is much more capital intensive than other sectors in the shipping industry, as its network-based service with regular frequencies requires a substantial amount of capital for acquiring a fleet consisting of multiple vessels. In addition, liner shipping operations require higher overhead costs to deal with shore-based activity and documentation.

${ }^{33}$ The OSRA of 1998 is the amendment to the Shipping Act of 1984 for stimulating market-driven competition in the liner shipping industry.

${ }^{34}$ It is possible that this divergence can be attributed to the somewhat different time-periods and shipping segments examined with more M\&As in container/liner shipping being triggered at bad times than good times.
} 
received three bids in 2004 and was finally acquired by a competitor in the same year - part of the reason the company became a takeover target was its inefficient corporate governance coupled with conflicts between founding-family members and major shareholders. Further, Merikas et al. (2011) compare the financial performance of 60 shipping companies involved in M\&A deals consummated during 1994-2009. They document that acquirers tend to outperform targets based on five financial criteria (ROA, gross margin, enterprise value, debt-to-capital, and debt-to-market capitalisation), highlighting that M\&As are driven by the desire to improve inefficient and less profitable targets. Finally, Yeo (2013) focuses on the geographical distance between acquiring and target companies as a key determinant of shipping M\&A activity, examining 120 transactions in the liner segment consummated during 2006-2007. Results indicate that the geographical distance negatively impacts takeover flows; that is, there is more M\&A activity among firms located closer to each other. The rationale behind the argument is that information cost between acquirers and targets tends to increase with geographical distance. The author also reports that the larger the company size the higher the probability for interregional and cross-border M\&As.

Despite the sound economic and/or strategic rationale behind M\&A activity, one of the stylised facts in the corporate finance literature is that business combinations tend to destroy value for acquiring companies more often than they create, while the bulk of the gains from the transactions is typically captured by target companies (Bruner, 2002). In contrast, the vast majority of studies in shipping finance focusing on business consolidation of shipping companies document that both acquiring, and target companies achieve positive gains around the deal announcement date. The general M\&A literature has also identified a plethora of determinants for acquisition gains ranging from deal and company characteristics (e.g. method of payment, company size, public status of target, company valuation, among others) to market-wide factors (e.g. the degree of investor protection, market valuation cycle, competition in the corporate takeover market, among others).

Early studies on value creation from M\&As mostly focus on a small number of M\&A cases. Panayides and Gong (2002) examine the stock market reaction to two deals in the liner segment (one between P\&O and Nedlloyd, the another between NOL and APL) completed in 1997. They report that the average Cumulative Abnormal Returns (CARs) to acquirers and targets, measured over the 11 days around the deal announcement (from day -5 to +5 ), are $83 \%$ and $148 \%$, respectively. ${ }^{35}$ Syriopoulos and Theotokas (2007) focus on the tramp sector and examine three bids for acquiring Stelmar Shipping that were carried out during 2004 and find negative (positive) acquirer (target) returns, consistent with the general consensus in the M\&A literature. Using various event windows, they document that the average acquirer CAR ranges from $-22.4 \%$ to $1.58 \%$, while that of the target is between $5.06 \%$ and $22.13 \%$. Moreover, Samitas and Kenourgios (2007) present mixed results on the gains of tramp shipping acquirers listed on NYSE and NASDAQ for the period 2004-2007. They find an average 5-day acquirer CARs of between $-0.3 \%$ and $0.8 \%$ for various event windows, while CARs tend to be generally positive for post-announcement windows. Choi and Yoshida (2013) examine the long-term operating performance of two M\&A deals of Japanese shipping companies (one between NYK and Showa,

${ }^{35}$ CARs in M\&As is the sum of the Abnormal Returns (AR), differences between the expected return on a stock and its actual return, over a window of $\left[-\mathrm{t}_{1},+\mathrm{t}_{2}\right]$ centred around the deal announcement. 
the another between OSK and Navix) carried out in 1998. They report enhanced market share for the combined entities driven by the aggregation of their fleets, as well as, improvements in asset turnover, profitability, and gearing ratio during the 5-year post-merger period.

While the above studies offer valuable insights on the benefits of shipping M\&As, their conclusions can be hardly generalised due to their mostly exploratory nature reflected in restrictive sample sizes and potential sample selection bias. There are three recent studies that provide more comprehensive evidence based on larger samples. Darkow et al. (2008) investigate value creation from $200 \mathrm{M} \& A$ s between logistics companies that took place globally for the period 1991-2006 and report that both acquiring and target companies achieve positive 3 day CARs of roughly $1.6 \%$ and $10.6 \%$, respectively. ${ }^{36}$ Moreover, the synergistic gains, proxied for by the value-weighted average of acquirer and target abnormal returns, are larger for horizontal, cross-border and larger deals. Andreou et al. (2012) examine a sample of 285 M\&A deals in the U.S. transportation industry (railroad, trucking shipping and freight service) consummated between 1980 and 2009. They report CARs to acquiring and target companies of $2.3 \%$ and $24.5 \%$, respectively, during the event window $[-10,+1]$. In contrast to Darkow et al. (2008), they document that vertical integration yields higher synergistic gains relative to horizontal consolidation. It is possible that this divergence can be attributed to differences in the regions examined, time periods and event windows employed in the two studies. In fact, some findings in Darkow et al. (2008) when utilising a pre-announcement window skewed towards the preannouncement period [-20, -1] - similar to that in Andreou et al. (2012) - point to the outperformance of vertical deals.

Finally, Alexandrou et al. (2014) examine the most comprehensive sample consisting of 1,266 global M\&A deals in freight shipping, passenger shipping and cargo handling segments during 1984-2011. Consistent with the findings in Darkow et al. (2008) and Andreou et al. (2012), the study documents that both acquirers and targets realise positive CARs of $1.2 \%$ and $3.3 \%$ over the 4 day $[-3,+1]$ around the deal announcements. Moreover, a particularly compelling result in this study is the outperformance of acquisitions of publicly listed targets compared to those of private companies. This is inconsistent with previous evidence that acquirers achieve higher gains when buying private targets, which has been largely attributed to the creation of blockholders leading to better post-merger monitoring (Chang, 1998), as well as, to the liquidity discount of non-tradeable target shares (Faccio et al., 2006). Although Alexandrou et al. (2014) discuss possible explanations for the under-performance of private deals, such as the likelihood of private targets attracting hefty premiums due to their superior bargaining power or strategic importance of private targets (such as access to regional markets and sector-specific know-how), there is no concrete evidence that supports this conjecture which would require additional investigation into the characteristics of these deals. For example, Conn et al. (2005) document that acquisitions of listed targets results in non-negative announcement returns for UK acquirers in cross-border deals. Also, Alexandridis et al. (2010) report positive announcement returns for public acquisitions in regions where there is less competition in the market for corporate control.

\footnotetext{
${ }^{36}$ According to the authors' own definition, the logistics industry covers all sub-sectors with first two-digit Standard Industrial Classification (SIC) code of 40-49 including rail transportation, passenger transportation, trucking, shipping, parcel delivery and related services.
} 
Accordingly, the higher announcement returns in acquisitions of listed targets may result from deals in countries where the takeover market is less competitive.

The findings of the extant empirical literature on shipping M\&As are summarised in Table 8. Further research in the area on inorganic corporate investment in the shipping industry could focus on a number of questions that remain unaddressed. First, prior studies have not examined value creation differentials among various segments within the shipping industry (e.g. dry bulk, tanker, liner, passenger, and offshore). Although Alexandrou et al. (2014) provide a comparison among shipping, passenger shipping and cargo handling segments, a more detailed classification, beyond employing SIC codes for industry classification, could provide insights on the attributes of M\&As within the different ship-owning segments as well as shipping services. Further, the utilisation of SIC codes might fail to provide clear-cut segmentation for service industries, such as shipping (Walker and Murphy, 2001) while discrepancies among popular databases in reporting company SIC codes (Guenther and Rosman, 1994) might result in sub- optimal segmentation of shipping companies based on business areas. Accordingly, future research should concentrate is examining the drivers of value creation in M\&As based on a more comprehensive and consistent segmentation of shipping companies in business areas or subsegments of interest.

Second, considering PE as an alternative funding source has become increasingly important amid the current credit deadlock which has affected traditional funding sources such as bank loans, the participation of PE funds in the market for corporate control in the shipping industry also calls for further investigation. ${ }^{37}$ Previous literature largely suggests that PE transactions enhance the target's shareholder value (Renneboog et al. 2007). Thus, the shareholder wealth effects of shipping M\&A deals by private equity companies as well as their determinants deserves further investigation.

The financing choice in shipping M\&As is another underexplored area. Since most transactions require sizeable capital, the choice of the payment currency can have a significant effect on the ownership and capital structure of the combined entities following the deal completion. ${ }^{38}$ From the perspective of an acquiring company, the choice of payment method in M\&As involves a trade-off between the ownership dilution from stock-swap offerings and potential financial distress costs from cash offerings (Faccio and Masulis, 2005). Considering the typically highly concentrated ownership of shipping companies they are likely to opt for cash offers to avoid ownership dilution. Yet, shipping is a notably highly leveraged industry, which provides an incentive to pay with stock. These contradictory dynamics on the financing choice of shipping M\&As along with their wealth effects deserve further investigation.

\footnotetext{
${ }^{37}$ As pointed out in Alexandridis and Singh (2016) around 23\% of acquirers in shipping M\&A during the period 1990-2014 are financial institutions (i.e. banks, private equity companies and investment holdings).

${ }^{38}$ For example, if an acquirer pays for the deal with cash, an increase in financial leverage of the merged company is expected since issuing debt is the major funding source for cash offers, considering liquidity constraints, lower issuance costs and tax benefits. Alternatively, if a deal is a stock-for-stock exchange, it is likely to end up with creation of additional block-holders.
} 


\section{Corporate Governance of Shipping Companies}

Given the high degree of capital intensiveness associated with the shipping industry along with the more recent trend of attracting external funding from public equity, bond markets and private investors, the governance of ship-owning has become a focal area of research. The role of corporate governance is especially important for publicly listed shipping companies where the separation of ownership and control becomes more pronounced and information asymmetry and conflicts of interest between shareholders and managers give rise to agency problems (Jensen and Meckling, 1976). Corporate governance entails the legal, institutional and cultural mechanisms to reduce these agency problems (John and Senbet, 1998) and enables shareholders to monitor managers more effectively and align their interests. It also has an important role to play as a key risk management tool, considering that regulators and industry supervisory and policy bodies have gradually become more vigilant.

Shipping companies have traditionally been conservative and this characteristic is reflected well in the concentrated ownership structure prevalent in the shipping industry (Glave et al., 2014). Ownership in a shipowning company tends to be concentrated in the hands of a founding-family and a dual role Chairperson-CEO representing the interests of the family is also common practice (Theotokas, 2007). In a survey of the governance structure in 27 Greek shipping companies, Koufopoulos et al. (2010) report relatively small board size (with 4.4 director son average), low board independence (with only 30\% independent directors) and high incidence of CEOChairperson duality (55.5\%). Tsionas et al. (2012) find that the average ownership of the largest shareholders in 126 publicly listed shipping companies is $31.15 \%$ and document no significant variations in ownership concentration across different institutional environments in North America, Europe and Asia. Pastra et al. (2015) discuss the findings of the Hellenic Observatory of Corporate Governance (HOCG) about board characteristics (age, gender, tenure, cross directorships, independent directors, board size, and CEO duality) of Greek-owned publicly listed shipping companies between 2001-2012. They observe that in 15 out of 28 companies the CEO is also the Chairman, the typical board size is 6-7 members while directors stay in office for 48.33 months on average. They argue that diversity in corporate boards is poor with only13 out of 305 seats being held by women.

Although the subject of corporate governance has attracted great attention from academics and practitioners alike, there is a great deal of disagreement on the effectiveness of existing governance mechanisms (Shleifer and Vishny, 1997), and the impact of different corporate governance dimensions, such as ownership structures and characteristics of corporate boards. For example, family ownership, which is common among shipping companies, can effectively reduce agency costs by enhancing monitoring (Demsetz and Lehn, 1985) and inciting long-term commitment (Anderson et al., 2003). Yet, family ownership can also be associated with conflicts of interest between family and non-family members (DeAngelo and DeAngelo, 1985) as well as a managerial entrenchment effect (Gomez-Mejia et al., 2001). The literature on corporate governance in the shipping industry is divided in terms of the effectiveness of most governance attributes, with the exception of the positive association between family ownership and financial performance (Randøy et al., 2003; Syriopoulos and Tsatsaronis, 2011). 
Randøy et al. (2003) examine the corporate governance of 32 publicly listed shipping companies in Norway and Sweden and find that their financial performance is positively associated with the incidence of founding family CEOs and board independence (percentage of outside directors). Syriopoulos and Tsatsaronis (2011) find a positive relation between the presence of founding family CEOs and company performance in a sample of 11 Greek shipping companies listed in U.S. exchanges. Further, there appears to be a curvilinear relation between the financial performance of Greek shipping companies and board ownership (percentage of ownership controlled by board members), where profitability increases with the level of insider ownership at a diminishing and eventually negative rate. ${ }^{39}$ Syriopoulos and Tsatsaronis (2012) document that CEO-Chairperson duality exerts a negative impact on financial performance in terms of return-on-equity and return-on-assets for 21 U.S. publicly listed shipping companies. Tsionas et al. (2012) investigate the association between ownership concentration (ownership of largest shareholder) and company performance for 126 public shipping companies in three major economic blocks (North America, Europe and Asia) and report a positive and bi-directional relationship.

Andreou et al. (2014) examine the impact of corporate governance on financial management and company performance. Using the sample of 32 publicly listed U.S. shipping companies, they investigate how earnings management, sub-optimal investment and company performance are affected by three dimensions of corporate governance - ownership structure, board structure and CEO duality. The results indicate that some corporate governance mechanisms can effectively mitigate agency costs, and in effect, improve financial management and performance, ultimately enhancing company value. The authors also document that: (i) earnings management is positively associated with board ownership; (ii) the over-investment problem can be mitigated the larger the board size, when a corporate governance committee is in place and the more the busy directors (percentage of directors serving on other companies); (iii) financial performance is positively linked to CEO duality and the presence of a governance committee, but negatively to board size ${ }^{40}$; and (iv) that company value is positively associated to board size and the number of busy directors. Table 9 provides a summary of the evidence in all papers discussed above.

Considering the perceived importance of corporate governance for the future of the shipping industry, a number of issues deserve further investigation. First, existing research on the role of independent directors fails to shed light on whether the introduction of such outside monitoring improves performance of shipping companies. In the light of the evidence in the general finance literature that stock ownership of independent directors is one of the most consistent predictors of company performance among other corporate governance indices and variables (Bhagat et al., 2008) future research should consider whether independent director ownership in the shipping industry can also serve as an effective interest alignment vehicle that positively affects company performance. Along these lines, the impact of board attributes such as past specialisation and experience (generalists vs. specialists) of corporate board members and the management team (see for example, Kroll et al., 2008; Custodio et al., 2013) have been largely overlooked in

\footnotetext{
39 The association between board ownership and financial performance (profitability) is found to be insignificant for Norwegian and Swedish shipping companies in Randøy et al. (2003).

${ }^{40}$ The positive impact of CEO duality on company performance is also consistent with Syriopoulos and Tsatsaronis (2012) findings.
} 
shipping-oriented research although they are particularly important dimensions of corporate governance for shipping companies. A third and related point is that the board structure of listed shipping companies, that have recently attracted more institutional and private equity investors than in the past, has evolved significantly over time. Yet the effect of this dynamic on corporate financing, investment decisions and company performance in general remains unexplored.

\section{Risk Measurement and Management in Shipping}

As highlighted earlier in the paper, operating within the shipping industry entails significant business, operational and financial risks. Perhaps the most important source of risk for a shipping company is the freight-rate risk, which refers to the variability in the earnings of a shipping company due to changes in freight rates. This is because volatility in the freight market has a direct impact on the profitability of the company. Another important risk exposure is the socalled asset-price risk which arises from fluctuations in the value of the company's assets (vessels) (see Alizadeh and Nomikos, 2012). Such fluctuations affect not only the book value of a ship-owning company but also its creditworthiness, since it is directly associated with the ability to service debt obligations. Bunker fuel price fluctuations can also affect profit margins, since bunker fuel costs, on average, account for more than 60-70 percent of the total voyage costs. Further, credit risk has a notable impact on the short- and long-run performance of shipping businesses, encompassing the uncertainty about whether a counter-party to a transaction will perform its financial obligations in full and on time. Credit risk is focal in the shipping business as most of the deals, trades and contracts are negotiated directly between the counterparties (bilateral OTC agreements). Interest rate risk is another form of risk pertaining shipping business, given its capital-intensive nature, and arises from unanticipated changes in floating interest rates which can in turn give rise to cash-flow and liquidity problems. Finally, foreign exchange rate fluctuation is another important source of risk in shipping since due to the international nature of the business most major revenue streams are in US\$, while a number of capital expenditures in practice are payable in different currency.

Section 6.1 discusses studies devoted on freight rate volatility modeling and the existence of volatility spillovers across freight rates and the vessel prices of different segments of the shipping industry. Aside from recognizing the sources of risk and measuring the associated exposures to each type of risk, shipping market participants also need to manage risks in an effective way. Given that freight derivatives have been extensively used for this purpose, the following sections is devoted on reviewing the empirical evidence associated with the most important features of this particular asset class.

\subsection{Freight rate volatility and volatility spillovers across shipping segments}

The building block of financial risk management in shipping lies on the business risk shipping companies face, which is primarily associated with their cash-flow generating ability. Cashflows in the shipping business are dependent on the ability of the shipping company to charter its vessels in attractive freight rates and receive payment of the agreed freight rates on time; along with its ability to time correctly the vessel S\&P market and benefit through asset-play (trading of ships). Naturally, cash-flows in the shipping industry are affected by the 
diversification of the fleet its shipping company owns and operates. A well-diversified fleet, among types and sizes of vessels, offers the benefit of an overall lower risk regarding the cashflow generating ability of a shipping company. However, the shipping industry is characterized by a distinct segmentation effect, as the demand for the transportation service varies according to the cargo transported and the size and type of vessels employed. ${ }^{41}$

Kavussanos (1996a; 1996b; 1997; 2003) was the first to document the segmentation effect in both freight rates and vessel prices for different types and vessel sizes; that is, the smaller the vessel and the more long-term the time-charter contract, the lower the risk from vessel operations and chartering activities, respectively. This segmentation effect is induced by different segments of the shipping industry typically following quite distinct business cycles, which are in turn, primarily driven by the demand for the respective commodities transported (Kavussanos and Visvikis, 2006a; Nomikos and Alizadeh, 2002; 2010). Even if the market segmentation effect in shipping freight rates and vessel prices is well documented, shipping segments are to a great extent inter-related (Stopford, 2009). Moreover, several shipping companies hold a welldiversified fleet and enter different market segments. Therefore, demand and supply imbalances in one segment can quickly ripple across other industry segments which is why the examination of freight rate and vessel price risk (volatility) and return spillovers between different shipping segments has received much attention in the relevant literature. Such spillover effects have a number of implications for participants in the shipping market, such as ship-lending financial institutions, investors, regulators, shipowners and charterers alike. Accordingly, shipping freight rates directly affect the operational cash-flows generated by shipping companies, which are of focal importance to institutional investors financing shipping projects. Volatility spillovers indicate the extent to which a diversified fleet can act as an insurance mechanism for a shiplending bank when assessing the default risk of a specific ship obligor.

Several studies have examined the spillovers of information between the returns and volatilities of freight rates between different segments of the shipping industry. Kavussanos (1996a; 2003) utilises monthly data on spot and time-charter freight rates for the dry bulk and tanker segments, respectively, and documents a pronounced segmentation effect when modelling the time-varying volatilities (with GARCH-type models) of different vessel sizes. Kavussanos (1997) extends the examination of volatility spillovers into dry bulk second-hand vessel prices and provides empirical evidence supporting the existence of the segmentation effect. In a related study, Chen et al. (2010) investigate daily freight rates over the period 1999-2008 and provide evidence that volatility dynamics between Capesize and Panamax freight rates change over time. Similarly, Drobetz et al. (2012) examine daily data over the period 1999-2011 and document significant spillovers among time-varying freight rate volatilities for the dry bulk and tanker segments. Finally, Tsouknidis (2016) utilizes shipping freight rate indices for the dry bulk and tanker

\footnotetext{
${ }^{41}$ Vessels employed in the liner sector are classified into Feeder (100 to 500 twenty-foot equivalent units or TEU), Feedermax (500 to 1,000 TEU), Handysize (1,000 to 2,000 TEU), Sub-Panamax (2,000 to 3,000 TEU), Panamax (3,000 to 4,000 TEU) and Post-Panamax (more than 4,000 TEU). The dry bulk sector differentiates into five categories per cargo-carrying capacity: Handysize (20,000 to 35,000 dwt), Handymax (35,000 to 45,000 dwt), Supramax (45,000 to 55,000 dwt), Panamax (60,000 to 75,000 dwt) and Capesize (more than 80,000 dwt). The tanker sector is also classified in five sub-sectors: Handysize (20,000 to 45,000 dwt), Panamax (50,000 to 80,000 dwt), Aframax (80,000 to $120,000 \mathrm{dwt})$, Suezmax (130,000 to 160,000 dwt) and Very Large Crude Carriers (VLCC) (more than 160,000 dwt, typically around 250,000 to 300,000 dwt).
} 
segments over the period 2006-2015 and shows that freight rate volatility spillovers are timevarying across the different freight segments. This result is more pronounced during the 2008 global financial crisis.

In relation to the aforementioned shipping sub-sector diversification effect and the unique factors affecting freight rates in each segment, a number of macroeconomic factors have also been found in the literature to determine freight rates, such as the state of the world economy, bunker prices, international seaborne trade, newbuilding deliveries, available ship tonnage, scrapping of vessels, among others. Dai et al. (2015) investigate the newbuilding vessel price volatility and report that freight rate volatility, as expected, is the most important determinant. Shipyard capacity change, exchange rate volatility, and shipbuilding cost volatility are also found to be important determinants. Alizadeh and Talley (2011a) provide, for the first time, a systematic investigation of the microeconomic determinants of shipping freight rates, using a large dry bulk sample from 2003 to 2009. Results indicate that freight rates are positively related to the length of the laycan period and the vessel size (dwt), and that a simultaneous relationship exists between freight rates and lengths of the laycan periods. Finally, they report that laycan periods vary directly with freight rates and indirectly with freight rate volatility. In a similar study, Alizadeh and Talley (2011b) investigate the microeconomic factors that determine tanker freight rates, using a sample from 2006 to 2009. The duration of the laycan period, the vessel's hull type, fixture deadweight utilization ratio, vessel age and voyage routes are found as important determinants of tanker freight rates. The above findings can be used by practitioners in negotiating freight rates and charterparties. The literature on risk-return segmentation provides clear and convincing evidence that different segments within the shipping industry are interconnected and the associations are time-varying (see Table 10). Research topics in the area deserving further attention is the interrelationship with shipping freight derivatives as discussed in Section 6.3, but also what is the impact of the vessel technological advancements, the vessel conversions and retrofitting, as well as the new regulations on emissions and ballast water treatments on the market segmentation in shipping.

\subsection{Measuring Market Risk in Shipping}

A number of studies have focused on the quantification of market risk in shipping freight markets. Kavussanos and Dimitrakopoulos (2007 and 2011) develop a framework for the measurement of market risk in shipping, by employing two alternative risk measures: Value-atRisk (VaR) and Expected Shortfall (ES). The authors provide an in-depth assessment of the forecasts produced by alternative $\mathrm{VaR}$ and $\mathrm{ES}$ models for short- and medium-term risk exposures in the tanker sector. The results suggest that the parametric approach of GARCH models and the non-parametric approach of Filtered Historical Simulation produce the most accurate forecasts for short-term (daily) risk. However, when drawing forecasts for long-term risk the most accurate method is the empirically scaled historical simulation model.

In another study, Lu et al. (2007), examine a freight rate index of the dry-bulk sub-sector and report that the most accurate approximations of market risk $(\mathrm{VaR})$ are produced by the parametric approach of a Generalized Error Distribution (GED) Exponential GARCH model. In a similar study, Angelidis and Skiadopoulos (2008) apply several parametric and non-parametric 
$\mathrm{VaR}$ models in the dry-bulk and tanker freight rates and suggest that the simplest non-parametric methods are producing the most accurate VaR forecasts.

\subsection{Managing Business Risks in Shipping with Freight Derivatives}

Despite the very significant risks involved in the shipping business and the importance of effectively managing them, utilising financial derivatives as a way to mitigate such risks has a relatively short history. Freight derivatives allow for managing exposures in freight rates, while bunker fuel derivatives are used to manage exposures to fluctuations in bunker fuel prices. Nonetheless, studies devoted on freight derivatives are notably less than the ones devoted on other commodity derivatives markets. This can be partially attributed to the challenge of obtaining accurate data almost until the mid-2000's, when clearing houses (market makers) first offered freight derivatives services, which is when trading activity and prices for this asset class started being systematically recorded.

The first freight derivatives contract, introduced in 1985 and traded until 2002, was the so-called Baltic International Freight Futures (BIFFEX) contract written on the Baltic Freight Index (BFI) and trading in the London International Financial Futures Exchange (LIFFE), while Forward Freight Agreements (FFAs) were introduced in 1992 as OTC derivatives contracts. FFA contracts are private, principal-to-principal Contracts-for-Difference (CFDs) between a seller and a buyer, who agree to settle a freight rate, for a pre-specified quantity of cargo or type of vessel, for typically one, or a combination, of the major trade routes of the dry-bulk, tanker or container sub-sectors of the shipping industry. Kavussanos and Visvikis (2006a, 2007, 2011, 2014); Kavussanos (2002 and 2010); Kavussanos et al. (2014a) and Alizadeh and Nomikos (2009; 2011) provide comprehensive discussion and applications of the freight derivatives market; while Kavussanos and Visvikis (2006b and 2008) and Kavussanos, et al. (2014b) have conducted surveys of the empirical literature on this asset class.

A number of researchers have conducted surveys studies to gauge awareness of freight derivatives among shipping market participants and their attitude towards this hedging tool. To this end, Cullinane (1991) investigate the attitudes of shipowners towards the now non-existent BIFFEX contract. The author collected questionnaire replies from a sample of 85 shipowners resident across four countries (UK, Greece, Hong Kong and Norway). The results suggest that shipping markets' participants were fully aware of the existence of the BIFFEX contract as a way to hedge freight rate risk. However, the majority of shipowners surveyed did not consider the BIFFEX contract as an effective hedging mechanism. In another survey study, Dinwoodie and Morris (2003) explore the attitude of tanker shipowners and charterers towards hedging freight rate risk through FFAs. Their findings suggest that despite the fact that FFAs are widely perceived as an important step towards managing freight rate risk, several respondents were not familiar with them and the great majority had never utilised them. In turn, Kavussanos, et al. (2007) investigate common perceptions regarding the use of shipping derivatives by Greek shipowners operating within the dry-bulk and tanker segments. The results indicate that Greek shipowners were reluctant towards the use of FFAs for managing freight rate risk mainly because of the issues of thin trading and high credit risk such contracts entail. The following sections review the evidence on the price discovery and hedging effectiveness functions of freight 
derivatives, their forecasting performance and impact on the physical freight rate market, with the associated market microstructure effects and options pricing.

\subsubsection{Price discovery, economic market relationships and forecast performance}

One of the most important research questions in the freight derivatives literature is whether trading activity in the derivatives market leads observed fluctuations in the corresponding spot market. Several empirical studies have been published on this issue, investigating if the derivatives market contains information regarding the future evolution of the spot market this could be exploited by shipping market participants for realizing profits by trading in both markets. One important feature that makes the shipping derivatives market distinct from other commodity and financial derivatives markets, investigated in the mainstream finance literature, is that the underlying asset (freight service) is a non-storable commodity. The non-storable nature of freight rates implies that the costof-carry (storage) relationship between underlying (spot) and derivative prices does not hold in shipping, contrary to other financial and commodity derivatives markets. Accordingly, lead-lag relation between spot and freight derivatives prices is generally not as pronounced as for other storable assets. The first empirical studies in the area are from Kavussanos and Nomikos (1999, 2003) and Haigh (2000) who examine the validity of the unbiasedness hypothesis in the early freight derivatives market of BIFFEX, using the empirical estimation framework of cointegration techniques. Specifically, Kavussanos and Nomikos $(1999 ; 2003)$ reveal that the unbiasedness hypothesis in the BIFFEX market holds for futures prices of one- and two-months from maturity. The authors attribute this finding to the fact that these short in maturity freight futures contracts can be regarded as unbiased forecasts of the realised spot freight prices.

Kavussanos and Visvikis (2004) was the first study on the FFA market, exploring empirically the lead-lag relationships between FFA and spot freight prices. The results reveal a bi-directional causal relationship between spot and FFA returns. However, causality tests employed suggest that causality from FFA to spot returns runs stronger than in the opposite direction for the great majority of the freight routes investigated. In turn, the results for volatility spillovers suggest that the volatility of the FFA contracts account for a large percentage of the observed volatility of the corresponding spot freight rates across all routes examined. In another study, Kavussanos, et al. (2004b) explore the relationship between FFA prices and spot prices of the underlying asset at maturity and reveal that FFA prices of one- and two-month prior to maturity are unbiased predictors of the realised spot prices at maturity in all investigated routes. The same results are mixed for the case of three-month FFAs contracts.

The unbiasedness hypothesis has also been studied by Alizadeh, et al. (2007), where the implied forward six-month time-charter rates in the dry-bulk freight market have been shown to be efficient and unbiased predictors of the future time-charter freight rates. The authors also report that even if the unbiasedness hypothesis is true on average, shipping market players can still generate economic profits by following technical analysis rules for their chartering strategies. In a related study, Chou and Huang (2010) investigate the interactions between the FFA market and the global steel price index and report that the global steel price index exhibits significant forecasting power for the FFA prices. In a related study, Li, et al. (2014) explore spillover effects and dynamic correlations between spot freight rates and freight derivatives prices. The results 
reveal unilateral spillovers from one-month FFA to spot markets returns, while these relationships are bilateral between one-month and two-month FFA contracts. The same bilateral relationships hold also for the case of volatility spillovers effects.

Kavussanos, et al. (2010 and 2014a) examine cross-market information flows and spillover effects between the freight derivatives market (FFAs) and commodity futures markets. Their results point to the existence of significant spillover effects between the two, and specifically with direction from the commodity futures to the freight derivatives market. Thus, shipping market players may benefit by monitoring fluctuations in the commodity futures markets and take appropriate positions in the FFA markets. In a related study, Alexandridis, et al. (2017a) explore for the first time the interactions across freight rates, freight futures, and freight options. The results reveal large information transmission in both returns and volatilities of the three markets examined. Specifically, the freight futures market leads fluctuations observed in the freight rate market, but freight options are shown to lag behind both the spot and futures freight markets. Yin, et al. (2017) explore the causality relationships between spot and futures freight markets for the dry bulk segment, along with the effects of exogenous factors, such as, market demand and supply forces, and economic indices. In all cases, the results document that freight rates follow a mean-reverting process which adjusts to long-run equilibrium levels.

The vast number of studies devoted on the interactions of the spot and derivatives freight markets and the growing empirical evidence documenting that freight derivatives market leads the freight spot market (price discovery function) has triggered a number of studies developing forecasting models for the spot market and assessing their performance. To this end, Chang and Chang (1996) have explored whether BIFFEX contract prices can be used to predict the spot dry-bulk shipping market, while Cullinane et al. (1999), building on Cullinane (1992), employ the Box-Jenkins Autoregressive Integrated Moving Average (ARIMA) methodology in order to test empirically whether the behaviour of the BFI has been altered due to the exclusion of all Handysize trades from its calculation. The authors propose that this exclusion had a weak impact on improving BFI behavior as a general freight rates index.

In another study, Batchelor, et al. (2007) empirically investigate the forecasting performance of a set of time-series models in predicting spot and FFA rates for the Panamax dry-bulk segment. The results reveal that using information from FFA prices enhances the forecasting performance of time-series models when predicting spot freight prices for all forecasting horizons up to 20 days ahead. In a related study, Lyridis, et al. (2013) rely on an Artificial Neural Network (ANN) in order to draw forecasts for FFAs. The ANN model trained and estimated can provide guidance to investors regarding which position (long or short) to take in the derivatives market. In the same vein, Zhang et al. (2014) propose a forecasting approach for spot freight rates based on the price discovery function of freight derivatives. The authors suggest that both spot and timecharter freight rates can improve forecasts of the spot freight rates. Adland et al. (2017a) suggest a multivariate model for the dynamic relationships of regional spot freight rates, by decomposing them into a common market factor (global arithmetic average of rates) and regional deviations. The model demonstrates the term structures of volatility and correlation between the regional freight rates and the market factor, which can help in the modelling and hedging of regional freight rates. Potential research topics that could contribute in this area are use of non-linear 
forecasting models that incorporate variables both from the physical freight and commodity markets, but also from their derivatives counterparts. In addition, deriving optimal portfolio rebalancing frequencies from those forecasting models would be a fruitful contribution both to academia and industry alike.

\subsubsection{The hedging performance of freight derivatives}

The hedging function of freight derivatives was the main driving force behind their development. For this reason, studies devoted on assessing the hedging performance (effectiveness) of such contracts have been prominent in the extant literature of freight derivatives. Early efforts by Thuong and Visscher (1990), Haralambides (1992), Haigh and Holt (2002) and Kavussanos and Nomikos (2000a, b, c) have assessed the hedging effectiveness of the BIFFEX freight derivatives market. Relatively, recent studies by Samitas and Tsakalos (2010) investigate how important is the use of financial derivatives for shipping companies and whether the use of such products have a notable (positive) impact on the shipping company's value by mitigating (hedging) specific business risks. The results suggest that the extensive use of derivatives products by shipping companies minimise their risk exposures and enhance their economic growth. In another study, Prokopczuk (2011) assesses the pricing and hedging functions of single-route drybulk freight futures contracts traded on the now non-existent International Maritime Exchange (IMAREX) market. The results reveal that the inclusion of a second stochastic factor significantly improves the pricing accuracy and hedging effectiveness of these freight futures contracts. In a similar study, Goulas and Skiadopoulos (2012) empirically examine if the IMAREX freight futures market is efficient over daily and weekly time horizons and reveal that IMAREX contracts are not efficient during shorter (daily) horizons.

For the FFA market, Kavussanos and Visvikis (2010) estimate constant and time-varying (dynamic) hedge ratios, using alternative specifications, and compare hedging effectiveness both in-sample and out-of-sample. In a related study, Alizadeh, et al. (2015a) explore the hedging effectiveness of tanker freight derivatives in six major tanker routes. The models employed, include the bivariate Markov Regime Switching (MRS)-GARCH model and the authors reveal the existence of distinct regimes within the tanker freight market. The MRS-GARCH model yields significant improvements in the hedging effectiveness when examined in-sample, but the results are mixed when examined out-of-sample. In another study, Adland and Jia (2017) explore over time the difference between the Baltic Exchange global trip-charter average and simulated earnings from a fleet of Capesize vessels. The authors use this difference as a measure of physical basis risk in the freight derivatives market. Results suggest that the increasing fleet size lowers the basis risk overall, but this diversification effect is relatively small. This is attributed by the authors to a moving-average effect in earnings, and to the fact that basis risk is on average larger for shorter hedging durations. In a related study, Alexandridis, et al. (2017b) introduce a portfolio-based methodological framework in order to examine the hedging performance of the container freight futures contracts. The authors use constructed portfolios comprising container, dry bulk and tanker freight futures along with portfolios of physical freight rates and examine whether there is a benefit from greater risk diversification effects of these combined portfolios. The results reveal that a decrease in freight rate risk up to $48 \%$ can be achieved by creating a diversified portfolio of physical freight rates, and an additional decrease of up to $8 \%$ on freight 
rate risk can be achieved when including futures contracts in the portfolio. Finally, Sun et al. (2018) investigate optimal combination hedge ratios for a shipowner trading crude oil and dry bulk freight rates simultaneously. Significant volatility spillovers are found between crude oil futures and FFAs, indicating that dynamic cross-market interactions have impacts on the hedging strategy. An under researched area of the hedging effectiveness of freight derivatives is their accounting treatment in terms of the International Accounting Standards (IAS) and the International Financial Reporting Standards (IFRS). The investigation of the effectiveness level of hedge accounting, which requires a strong correlation between the physical underlying asset and the FFA hedging contract, would provide new evidence to organizations but also to regulators.

\subsubsection{Market microstructure effects in freight derivatives}

A series of studies have investigated various special topics on freight derivatives. For example, the relationships across freight derivatives returns, trading volume, volatility and trading characteristics. To this end, Kavussanos, et al. (2004a) explore the effect of FFA trading on the spot market volatility of the dry-bulk Panamax segment. The results indicate that after FFA trading was introduced, the spot price volatility was reduced across all investigated routes. In addition, FFA trading in dry-bulk Panamax routes exerted a decreasing pressure on the asymmetry of volatility; while notably improving the quality and speed of information flow in the spot market. In another study, Koekebakker and Adland (2004) model the forward freight rate dynamics under a term-structure model. Their results indicate that the volatility of the forward curve is relatively high, reaching a peak for the one-year forward freight rate contracts.

Several studies have been devoted on the trading characteristics of FFA contracts. To this end, Batchelor, et al. (2005) investigate the existence of a positive relationship between the expected volatility and bid-ask spreads in the FFA Panamax market. This relationship is motivated by the rationale that the greater the variability in price, the greater the risk associated with the performance of the brokers. The results reveal the existence of a positive relationship between expected price volatility and bid-ask spreads across the great majority of the investigated Panamax routes. The authors conclude that an increasing bid-ask spread reflects an expectation for higher future volatility in the FFA Panamax market. In the same vein, Alizadeh (2013) provides empirical evidence of a positive and contemporaneous relationship between price volatility and trading volume in the dry-bulk FFA market. The results suggest that an increase in price volatility leads to lower future trading activity. In a related study, Alizadeh et al., (2015b) investigate the existence of liquidity premia in freight derivatives returns. Results indicate that liquidity is priced by the FFA market and that both the Amihud (2002) measure of illiquidity and the bid-ask spread explains a large percentage of the observed variation in freight derivatives returns. Finally, Nomikos and Doctor (2013) explore the profitability of trading rules and market timing strategies in freight rates and freight derivatives across available contracts and maturities. The results suggest that following the proposed trading rules outperforms the return of the buyand-hold benchmark strategy. 


\subsubsection{Freight options pricing}

Despite the fact that FFA contracts provide reasonable hedging effectiveness and allow market participants to "lock" a fixed freight rate over a period of time, they lack the flexibility to offer to their users the option to maintain the hedge if the market moves against them, but to also participate in the market when market conditions are favorable. This led to the creation of the freight options contracts, which in exchange for a fee (premium) provide this type of flexibility to their users. Empirical investigations of freight options are mainly concentrated on their pricing mechanism. For example, Tvedt (1998) derives an analytical pricing formula for European futures options on BIFFEX. This analytical formula takes into account special features related to the freight rate market, such as the fact that as the lay-up of vessels is always an option, and that the BFI as the underlying asset is never close to zero. For this reason, the authors assume that the BFI and the futures contracts on BFI are restricted downwards to a level above zero. The authors also assume that freight rates are mean reverting because of the existence of frictional capacity adjustments to changes in the demand for sea transportation.

In another study, Koekebakker, et al. (2007) introduce a mathematical framework for pricing Asian-type freight options. The authors assume that FFAs returns are lognormally distributed prior to the settlement period, but this assumption breaks down in the settlement period. For this reason, they propose an approximate structure in the settlement period for the FFA, deriving a closed-form option pricing formula for Asian call and put options on spot freight rate indices. In a related study, Nomikos et al. (2013) extend the lognormal representation of the dynamic process governing the risk neutral spot freight rates and propose a diffusion model which incorporates jumps of random magnitude and arrival to the process. The results reveal that the developed model of freight options' pricing is significantly improved when it incorporates jumps into the generating process instead of assuming the generic lognormal setting. Similarly, Kyriakou et al. (2017a) extend the diffusion model of Nomikos et al. (2013) by incorporating the mean-reverting property of freight rates. They find that the freight option valuation model exhibits significantly lower pricing errors than the generic lognormal model. Despite existing work on this area, there is still a motive for future research to further improve the freight option pricing performance by minimizing mispricings and establish models that yield fair (theoretical) freight options prices.

\subsubsection{Bunker fuel and vessel values derivatives}

Turning our attention to studies on alternative shipping derivatives markets, Mayr and Tamvakis (1999) investigate the causal relationship between refinery margins (crack spreads) of gasoline and heating oil futures contracts and physical Brent crude oil traded in New York Mercantile Exchange (NYMEX). The results reveal a unidirectional Granger-causality relationship from the two-month crack spread contract to crude oil imports. Thus, the authors suggest that crack spreads can serve as a leading indicator for short term developments in the tanker vessels demand. In another study, Alizadeh, et al. (2004) assess the hedging effectiveness of different crude oil and petroleum futures contracts on bunker fuel prices in Rotterdam, Singapore and Houston. Results reported indicate that out-of-sample the hedging effectiveness varies significantly across the bunker markets when using constant and time-varying hedge ratios. In 
addition, crude oil futures traded in the International Petroleum Exchange (IPE) exhibit the highest hedging effectiveness for the underlying spot bunker prices in Rotterdam and Singapore. In a related study, Alizadeh and Nomikos (2004) investigate the dynamics of the relationship between oil futures and the corresponding spot oil markets, along with their interactions with tanker spot freight rates. Specifically, the authors examine empirically the existence of a cost of carry relationship in the WTI futures market. In addition, they investigate whether the differential between futures-physical oil markets contains relevant information regarding the future evolution of the tanker freight rates. However, the reported results fail to confirm a statistically strong relationship between the two. This finding points to the existence of arbitrage opportunities between oil futures and tanker spot freight markets. Finally, Wang and Teo (2013) investigate a possible re-planning of the bunkering network configuration and financial hedging to reduce bunker fuel price risk in the container segment. The authors assume that the container liner network is initially planned, and then bunker fuel hedging is performed based on information regarding fuel consumption and the expectations for the future bunker fuel prices. Thus, the authors highlight the benefits of building an integrated supply chain for bunkers that combines network planning and bunker hedging activities.

Regarding vessel value derivatives, Adland, et al. (2004) suggest a framework on price the OTC sale \& purchase forward rate agreements for dry bulk vessels. They estimate the implied forward price from historical data for vessel prices and the term structure of freight rates. Results indicate that the unbiasedness hypothesis is rejected in all the investigated cases studied and supports the existence of a risk premium in the vessel derivatives prices.

Table 11 summarises the available empirical literature in derivatives and risk management in shipping. During almost the last three decades, there have been a number of research streams that investigate the major economic functions and market microstructure effects in the freight derivatives market. This market, however, has lost much of its trading liquidity since the international financial crisis of 2008. Future research in the area could potentially investigate the consequences from this major decrease in liquidity and also the market conditions that need to prevail in order for the freight derivatives market to rebound. Moreover, a notable restructuring of the Baltic Exchange's BDI was announced on $1^{\text {st }}$ March 2018 (the Handysize sector was removed), catering for the index becoming a tradable asset. Such market change can be relevant to investors holding dry bulk (or generally freight rate sensitive) portfolios (including banks and other financial intermediaries and funds). The economic functions of this new index and especially the cross-hedging opportunities it provides would be an interesting research avenue.

\section{Conclusion}

Three main drivers behind the voluminous nature of shipping finance research: First, the profound importance of the shipping industry in the global transportation system and its contribution to the economic welfare and development of nations. Second, the unique idiosyncratic characteristics of the shipping industry including its fragmented structure, high cyclicality, seasonality, volatility and capital-intensive nature. Third, the trend towards more shipping companies relying on global capital markets and investors to raise the required funds 
for shipping investments as well as the increasing tendency of governments to provide subsidies. The current survey paper is the first attempt, to the best of our knowledge, to provide a comprehensive and in-depth review of the shipping finance and investment literature. It examines 162 shipping finance studies published in 48 scholarly journals complemented with select books and book chapters between 1979-2018, presents a bibliometric analysis and identifies a number research gaps, shaping the future research agenda in shipping finance and investment.

\section{Acknowledgements}

The authors would like to thank the Editor-in-Chief and five anonymous reviewers for their valuable comments on an earlier version of the study. The responsibility for any remaining errors rests fully with the authors. 


\section{REFERENCES}

Abdullah, A., Hassan, R., Kassim, S. (2016). A conceptual framework for the application of Islamic private equity in internationfal shipping. Journal of Islamic Thought and Civilization, Special Issue: Islamic Finance and Banking, December, 115-137.

Acciaro, M. (2014). A real option application to investment in low-sulphur maritime transport. International Journal of Shipping and Transport Logistics, 6(2), 189-212.

Adland, R., Jia, H. (2008). Default risk in bulk shipping: A conceptual approach. Transportation Research Part E: Logistics and Transportation Review, 44(1), 152-163.

Adland, R., Jia, H. (2015). Shipping market integration - the case of sticky newbuilding prices. Maritime Economics \& Logistics, 17(4), 389-398.

Adland, R., Jia, H. (2017). Simulating physical basis risks in the Capesize freight market. Maritime Economics \& Logistic, 19, 196-210.

Adland, R., Jia, H., Koekebakker, S. (2004). The pricing of forward ship value agreements and the unbiasedness of implied forward prices in the second-hand market for ships. Maritime Economics \& Logistics, 6, 109-121.

Adland, R., Jia, H., Strandenes, S. P. (2006). Asset bubbles in shipping? An analysis of recent history in the drybulk market. Maritime Economics \& Logistics, 8, 223-233.

Adland, R., Koekebakker, S. (2004). Market efficiency in the second-hand market for bulk ships. Maritime Economics \& Logistics, 6(1), 1-15.

Adland, R., Koekebakker, S. (2007). Ship valuation using cross-sectional sales data. Maritime Economics \& Logistics. 9, $105-118$.

Adland, R., Benth, F. E., Koekebakker, S. (2017a). Multivariate modeling and analysis of regional ocean freight rates. Transportation Research Part E: Logistics and Transportation Review, doi: 10.1016/j.tre.2017.10.014.

Adland, R., Hansson, D., von der Wense, L. (2017b). Valuing cargo flexibility in oil transportation. Maritime Policy \& Management, 44(7), 803-814.

Adland, R., Noraas, J., Iversen R. S. (2017c). Capital structure determinants of shipbuilding companies. International Journal of Shipping and Transport Logistics, 9(6), 763-789.

Ahrenda, M., Drobetz, W., Nomikos, N. K. (2018). Corporate cash holdings in the shipping industry. Transportation Research Part E: Logistics and Transportation Review, 112, 107-124.

Albertijn, S., Bessler, W., Drobetz, W. (2011). Financing shipping companies and shipping operations: A risk management perspective. Journal of Applied Corporate Finance, 23(4), 70-82.

Albertijn, S., Drobetz, W., Johns, M. (2016). Maritime investment appraisal and budgeting. In M. G. Kavussanos, I. D. Visvikis (Eds.), The International Handbook of Shipping Finance: Theory and Practice (pp. 285-313): Palgrave Macmillan, London.

Alexandridis, G., Petmezas, D., Travlos, N. G. (2010). Gains from mergers and acquisitions around the world: New evidence. Financial Management, 39(4), 1671-1695.

Alexandridis, G., Sahoo, S., Visvikis, I. D. (2017a). Economic information transmissions and liquidity between shipping markets: New evidence from freight derivatives. Transportation Research Part E: Logistics and Transportation Review, 98, 82-104.

Alexandridis, G., Sahoo, S., Song, D.-W., Visvikis, I. D. (2017b). Shipping risk management practice revisited: A new portfolio approach, Transportation Research Part A: Policy and Practice, doi: 10.1016/j.tra.2017.11.014.

Alexandridis, G., Singh, M. (2016). Mergers and acquisitions in shipping. In M. G. Kavussanos, I. D. Visvikis (Eds.), The International Handbook of Shipping Finance: Theory and Practice (pp. 371-413): Palgrave Macmillan, London.

Alexandrou, G., Gounopoulos, D., Thomas, H. M. (2014). Mergers and acquisitions in shipping. Transportation Research Part E: Logistics and Transportation Review, 61, 212-234.

Alexopoulos, I., Stratis, N. (2016). Structured finance in shipping. In M. G. Kavussanos, I. D. Visvikis (Eds.), The International Handbook of Shipping Finance: Theory and Practice (pp. 191-211): Palgrave Macmillan, London.

Alizadeh, A. H. (2013). Trading volume and volatility in the shipping forward freight market, Transportation Research Part E, Logistics and Transportation Review, 49, 250-265.

Alizadeh, A. H., Adland, R., Koekebakker, S. (2007). Predictive power and unbiasedness of implied forward charter rates, Journal of Forecasting, 26, 385-403.

Alizadeh, A. H., Huang, C-H., van Dellen, S. (2015a). A regime switching approach for hedging tanker shipping freight rates, Energy Economics, 49, 44-59.

Alizadeh, A. H., Kappou, N., Tsouknidis, D., Visvikis, I. D. (2015b). Liquidity risk premia in the international shipping derivatives market, Transportation Research Part E: Logistics and Transportation Review, 76, 58-75.

Alizadeh, A. H., Kavussanos, M. G., Menachof, D. A. (2004). Hedging against bunker price fluctuations using petroleum futures contracts: constant versus time-varying hedge ratios, Applied Economics, 36, 1337-1353.

Alizadeh, A. H., Nomikos, N. K. (2004). Cost of carry, causality and arbitrage between oil futures and tanker freight markets, Transportation Research Part E: Logistics and Transportation Review, 40, 297-316. 
Alizadeh, A. H., Nomikos, N. K. (2007). Investment timing and trading strategies in the sale and purchase market for ships. Transportation Research Part B: Methodological, 41(1), 126-143.

Alizadeh, A. H., Nomikos, N. K. (2009). Shipping derivatives and risk management. London: Palgrave MacMillan.

Alizadeh, A. H., Nomikos, N. K. (2012). Ship finance: Hedging ship price risk using freight derivatives. In W. K. Talley (Eds.), Blackwell Companion to Maritime Economics (pp. 433-451): Wiley-Blackwell.

Alizadeh, A. H., Talley, W. K (2011a). Vessel and voyage determinants of tanker freight rates and contract times, Transport Policy, 18, 665-675.

Alizadeh, A. H., Talley, W. K (2011b). Microeconomic determinants of dry bulk shipping rates and contract times, Transportation, 38, 561-579.

Alizadeh, A. H., Thanopoulou, H., Yip, T. L. (2017). Investors' behavior and dynamics of ship prices: A heterogeneous agent model. Transportation Research Part E: Logistics and Transportation Review, 106, 98 114.

Alizadeh, A.H., Nomikos, N. K. (2011). An investigation into the effect of risk management on the profitability of shipping investment and operations. In K. Cullinane, (Eds.), International Handbook of Maritime Economics Cheltenham: Edward Elgar.

Alkaraan, F., Northcott, D. (2006). Strategic capital investment decision-making: A role for emergent analysis tools?: A study of practice in large UK manufacturing companies. The British Accounting Review, 38(2), 149-173.

Amihud, Y. (2002). Illiquidity and stock returns: cross-section and time-series effects. Journal of Financial Markets, 5(1), 31-56.

Anderson, R. C., Mansi, S. A., Reeb, D. M. (2003). Founding family ownership and the agency cost of debt. Journal of Financial Economics, 68(2), 263-285.

Andreou, P. C., Louca, C., Panayides, P. M. (2012). Valuation effects of mergers and acquisitions in freight transportation. Transportation Research Part E: Logistics and Transportation Review, 48(6), 1221-1234.

Andreou, P. C., Louca, C., Panayides, P. M. (2014). Corporate governance, financial management decisions and firm performance: Evidence from the maritime industry. Transportation Research Part E: Logistics and Transportation Review, 63, 59-78.

Andriosopoulos, K., Doumpos, M., Papapostolou, N. C., Pouliasis, P. K. (2013). Portfolio optimization and index tracking for the shipping stock and freight markets using evolutionary algorithms. Transportation Research Part E: Logistics and Transportation Review, 52, 16-34.

Angelidis, T., Skiadopoulos, G. (2008). Measuring the market risk of freight rates: A value-at-risk approach, International Journal of Theoretical and Empirical Finance, 11, 447-469.

Axarloglou, K., Visvikis, I. D., Zarkos, S. (2013). The time dimension and value of flexibility in resource allocation: The case of the maritime industry. Transportation Research Part E: Logistics and Transportation Review, 52, $35-48$.

Baker, M., Wurgler, J. (2002). Market timing and capital structure. The Journal of Finance, 57(1), 1-32.

Balliauw, M. (2017). An analysis of entry and exit decisions in shipping markets under uncertainty, International Journal of Shipping and Transport Logistics, 9(5), 527-539.

Batchelor, R., Alizadeh, A. H., Visvikis, I. D. (2005). The relation between bid-ask Spreads and Price Volatility in Forward Markets, Journal of Derivatives \& Hedge Funds (formerly Derivatives Use, Trading \& Regulation), 11(2), 105-125.

Batchelor, R., Alizadeh, A. H., Visvikis, I. D. (2007). Forecasting spot and forward prices in the international freight market, International Journal of Forecasting, 23, 101-114.

Beenstock, M. (1985). A theory of ship prices. Maritime Policy \& Management, 12(3), 215-225.

Bendall, H. B., Stent, A. F. (2003). Investment strategies in market uncertainty. Maritime Policy \& Management, 30(4), 293-303.

Bendall, H. B., Stent, A. F. (2005). Ship investment under uncertainty: Valuing a real option on the maximum of several strategies. Maritime Economics \& Logistics, 7(1), 19-35.

Bendall, H. B., Stent, A. F. (2007). Maritime investment strategies with a portfolio of real options. Maritime Policy \& Management, 34(5), 441-452.

Bendall, H., Manger, G. (1991). Corporate investment decisions: what are the relevant criteria. Corporate Management, 43(3), 64-69.

Berg-Andreassen, J. A. (1990). Risk and investment decisions in non-liner shipping. Maritime Policy \& Management, 17(1), 23-30.

Bhagat, S., Bolton, B., Romano, R. (2008). The promise and peril of corporate governance indices. Columbia Law Review, 1803-1882.

Bjerksund, P., Ekern, S. (1995). Contingent claims evaluation of mean-reverting cash flows in shipping. In L. Trigeorgis (Ed.), Real Options in Capital Investment: Models, Strategies, and Applications (pp. 207-219): Praeger Publishers.

Black, F. (1972). Capital market equilibrium with restricted borrowing. The Journal of Business, 45(3), 444-455.

Bonfim, D. (2009). Credit risk drivers: Evaluating the contribution of firm levl information and of macroeconomic dynmics. Journal of Banking and Finance, 33(2), 281-299. 
Brooks, M. R., Ritchie, P. (2006). Mergers and acquisitions in the maritime transport industry 1996-2000. Transportation Journal, 7-22.

Bruner, R. F. (2002). Does M\&A pay? A survey of evidence for the decision-maker. Journal of Applied Finance, 12(1), 48-68.

Bruton, G. D., Filatotchev, I., Chahine, S., Wright, M. (2010). Governance, ownership structure, and performance of IPO firms: The impact of different types of private equity investors and institutional environments. Strategic Management Journal, 31(5), 491-509.

Bulut, E., Duru, O., Yoshida, S. (2013). Market entry, asset returns, and irrational exuberance: asset management anomalies in dry cargo shipping, International Journal of Shipping and Transport Logistics, 5(6), 652-667.

Burgess, K., Singh, P. J., Koroglu, R. (2006). Supply chain management: a structured literature review and implications for future research. International Journal of Operations \& Production Management, 26(7), 703729.

Catalyst Corporate Finance, 2016. Global Shipping Market Report, LLP.

Chang, C., Liao, G., Yu, X., Ni, Z. (2014). Information from relationship lending: Evidence from loan defaults in China. Journal of Money, Credit and Banking, 46(6), 1225-1257.

Chang, S. (1998). Takeovers of privately held targets, methods of payment, and bidder returns. The Journal of Finance, 53(2), 773-784.

Chang, Y., Chang, H. (1996). Predictability of the dry-bulk shipping market by BIFFEX, Maritime Policy \& Management, 23, 103-114.

Chava, S., Purnanandam, A. (2011). The effect of banking crisis on bank-dependent borrowers. Journal of Financial Economics, 99(1), 116-135.

Chen, L, Lesmond, D. A., Wei, J., (2007). Corporate yield spreds and bond liquidity. Journal of Finance, 62, 119149.

Chen, S., Meersman, H., van de Voorde, E. (2010). Dynamic interrelationships in returns and volatilities between Capesize and Panamax markets. Maritime Economics \& Logistics, 12(1), 65-90.

Choi, N. Y. H., Yoshida, S. (2013). Evaluation of M\&A effects in Japanese shipping companies: Case study of NYK \& Showa Line and OSK \& Navix Line. The Asian Journal of Shipping and Logistics, 29(1), 23-42.

Chou, H.-C., Chen, D.-H. (2018). The use of technical analysis in sale-and-purchase transactions of secondhand ships, Maritime Economics \& Logistics, 1-18, 10.1057/s41278-017-0096-2.

Chou, M.-T., Huang, B.-C. (2010). An analysis of the relationship between forward freight agreements and steel price index: An application of the vector ARMA model, African Journal of Business Management, 4(6), 11491154.

Clintworth, M., Boulougouris, E., Lee, B. S. (2017). Combining multicriteria decision analysis and cost-benefit analysis in the assessment of maritime projects financed by the European Investment Bank. Maritime Economics \& Logistics, 1-19, doi:10.1057/s41278-017-0072-X.

Conn, R. L., Cosh, A., Guest, P. M., Hughes, A. (2005). The impact on UK acquirers of domestic, cross-border, public and private acquisitions. Journal of Business Finance \& Accounting, 32(5-6), 815-870.

Cullinane, K. P.B. (1995). A portfolio analysis of market investments in dry bulk shipping. Transportation Research Part B: Methodological, 29(3), 181-200.

Cullinane, K. P. B. (1991). Who's Using BIFFEX? Results from a Survey of Shipowners, Maritime Policy and Management, 18: 79-91.

Cullinane, K. P. B. (1992). A Short-Term Adaptive Forecasting Model for BIFFEX Speculation: A Box-Jenkins Approach, Maritime Policy and Management, 19: 91-114.

Cullinane, K. P. B., Mason, K. J., Cape, M. B. (1999). A Comparison of Models for Forecasting the Baltic Freight Index: Box-Jenkins Revisited, International Journal of Maritime Economics, 1(2): 15-39.

Cullinane, K. P. B., Gong, X. (2002). The mispricing of transportation initial public offerings in the Chinese mainland and Hong Kong. Maritime Policy \& Management, 29(2), 107-118.

Cullinane, K. P.B., Panayides, P. M. (2000). The use of capital budgeting techniques among uk-based ship operators. International Journal of Maritime Economics, 2(4), 313-330.

Custódio, C., Ferreira, M. A., Matos, P. (2013). Generalists versus specialists: Lifetime work experience and chief executive officer pay. Journal of Financial Economics, 108(2), 471-492.

Dai, L., Hu, H., Chen, F., Zheng, J. (2015). The dynamics between newbuilding ship price volatility and freight volatility in dry bulk shipping market, International Journal of Shipping and Transport Logistics, 7(4), 393406.

Darkow, I.-L., Kaup, C., Schiereck, D. (2008). Determinants of merger \& acquisition success in global logistics. International Journal of Logistics: Research and Applications, 11(5), 333-345.

DeAngelo, H., DeAngelo, L. (1985). Managerial ownership of voting rights: A study of public corporations with dual classes of common stock. Journal of Financial Economics, 14(1), 33-69.

Del Gaudio, B. L. (2018). The financing of Italian shipping firms. International Research in Economics and Finance, 2(1), 26-32.

Demsetz, H., Lehn, K. (1985). The structure of corporate ownership: Causes and consequences. Journal of Political Economy, 93(6), 1155-1177. 
Devaud, J. M., Groussaud, G., Jacquet-Lagreze, E. (1980). UTADIS: Une méthode de construction de fonctions d'utilité additives rendant compte de jugements globaux. UTADIS: [A method for the construction of additive utility functions based on global judgments]. In: Proceedings of the European Working Group on MCDA. Bochum, Germany.

Dick-Nielsen, J., Feldhütter, P., Lando, D. (2012). Corporate bond liquidity before and after the onset of the subprime crisis. Journal of Financial Economics, 103(3), 471-492.

Dietrich, J. K., Sorensen, E. (1984). An application of logit analysis to prediction of merger targets. Journal of Business Research, 12(3), 393-402.

Dikos, G. N., Thomakos, D. D. (2012). Econometric testing of the real option hypothesis: evidence from investment in oil tankers. Empirical Economics, 42(1), 121-145.

Dimitras, A. I., Petropoulos, T., Constantinidou, I. (2002). Multi-criteria evaluation of loan applications in shipping. Journal of Multi-Criteria Decision Analysis, 11(4-5), 237-246.

Dinwoodie, J., Morris, J. (2003). Tanker forward freight agreements: The future for freight futures, Maritime Policy \& Management, 30, 45-58.

Drobetz, W., Gounopoulos, D., Merikas, A., Schroder, H. (2013). Capital structure decisions of globally-listed shipping companies. Transportation Research Part E: Logistics and Transportation Review, 52, 49-76.

Drobetz, W., Haller, R., Meier, I. (2016a). Cash flow sensitivities during normal and crisis times: Evidence from shipping. Transportation Research Part A: Policy and Practice, 90, 26-49.

Drobetz, W., Tsionas, M., Merikas, A., Merika, A. (2014). Corporate social responsibility and corporate performance: The case of international shipping. Transportation Research Part E: Logistics and Transportation Review, 71, 18-44.

Drobetz, W., Menzel, C., Schröder, H. (2016b). Systematic risk behavior in cyclical industries: The case of shipping. Transportation Research Part E: Logistics and Transportation Review, 88, 129-145.

Drobetz, W., Richter, T., Wambach, M. (2012). Dynamics of time-varying volatility in the dry bulk and tanker freight markets. Applied Financial Economics, 22(16), 1367-1384.

Drobetz, W., Schilling, D., Tegtmeier, L. (2010). Common risk factors in the returns of shipping stocks. Maritime Policy \& Management, 37(2), 93-120.

Drobetz, W., Tegtmeier, L. (2013). The development of a performance index for KG funds and a comparison with other shipping-related indices. Maritime Economics \& Logistics, 15(1), 32-71.

Evans, J. (1984). Some practical aspects of investment appraisal in shipping. Maritime Policy \& Management, 11(3), 197-222.

Faccio, M., Masulis, R. W. (2005). The choice of payment method in European mergers and acquisitions. The Journal of Finance, 60(3), 1345-1388.

Faccio, M., McConnell, J. J., Stolin, D. (2006). Returns to acquirers of listed and unlisted targets. Journal of Financial and Quantitative Analysis, 41(01), 197-220.

Fama, E. F., French, K. R. (1992). The cross-section of expected stock returns. The Journal of Finance, 47(2), 427465.

Fan, J. P., Wong, T. J., Zhang, T. (2007). Politically connected CEOs, corporate governance, and Post-IPO performance of China's newly partially privatized firms. Journal of Financial Economics, 84(2), 330-357.

Friewald, N., Jankowitsch, R., Subrahmanyam, M.G. (2012). Illiquidity or credit deterioration: a study of liquidity in the US corporate bond market during financial crises. Journal of Finance Economics, 105, 18-36.

Fusillo, M. (2009). Structural factors underlying mergers and acquisitions in liner shipping. Maritime Economics \& Logistics, 11(2), 209-226.

Gavalas, D., Syriopoulos, T. (2014). An integrated credit rating and loan quality model: application to bank shipping finance. Maritime Policy \& Management, 42(6), 533-554.

Gavalas, D., Syriopoulos, T. (2016). Selecting the optimum collateral in shipping finance. In T. Kramberger, V. Potočan, V. M. Ipavec (Eds.), Sustainable Logistics and Strategic Transportation Planning (pp. 295-327): IGI Global,

Gigerenzer, G. (1991). How to make cognitive illusions disappear: Beyond "heuristics and biases". European Review of Social Psychology, 2(1), 83-115.

Glave, T., Joerss, M., Saxon, S. (2014). The hidden opportunity in container shipping. McKinsey \& Company, November.

Glen, D. R. (2006). The modelling of dry bulk and tanker markets, Maritime Policy \& Management, 33, 431-445.

Goedhart, M. H., Koller, T., Rehm, W. (2006). Making capital structure support strategy. Insights \& Publications McKinsey \& Company.

Gomez-Mejia, L. R., Nunez-Nickel, M., Gutierrez, I. (2001). The role of family ties in agency contracts. Academy of Management Journal, 44(1), 81-95.

Gong, S. X., Ye, H.-Q., Zeng, Y. Y. (2013). Impacts of the recent financial crisis on ship financing in Hong Kong: a research note. Maritime Policy \& Management, 40(1), 1-9.

Gort, M. (1969). An economic disturbance theory of mergers. The Quarterly Journal of Economics, 624-642.

Goss, R. (1987). Assessing investments in shipping: a modular approach. Maritime Policy \& Management, 14(3), 197-225. 
Goulas, L., Skiadopoulos, G. (2012). Are freight futures markets efficient? Evidence from IMAREX, International Journal of Forecasting, 28, 644-659.

Goulielmos, A. M., Psifia. E. M. (2006a). Variations in charter rates for a time series between 1971 and 2002: Can we model them as an effective tool in shipping finance? International Journal of Transport Economics, 33(2), 257-278.

Goulielmos, A. M., Psifia. E. M. (2006b). Shipping finance: time to follow a new track? Maritime Policy \& Management, 33(3), 301-320.

Graham, J. R., Harvey, C. R. (2001). The theory and practice of corporate finance: Evidence from the field. Journal of Financial Economics, 60(2), 187-243.

Graham, J., Harvey, C. (2002). How do CFOs make Capital budgeting and capital structure decisions? Journal of Applied Corporate Finance, 15(1), 8-23.

Graham, J. R., Leary, M. T. (2011). A review of empirical capital structure research and directions for the future. Annual Review of Financial Economics, 3(1), 309-345.

Grammenos, C. T., Alizadeh, A. H., Papapostolou, N. C. (2007). Factors affecting the dynamics of yield premia on shipping seasoned high yield bonds. Transportation Research Part E: Logistics and Transportation Review, 43(5), 549-564.

Grammenos, C. T., Arkoulis, A. G. (1999). The long run performance of shipping initial public offerings. International Journal of Maritime Economics, 1(1), 71-93.

Grammenos, C. T., Arkoulis, A. G. (2003). Determinants of spreads on new high yield bonds of shipping companies. Transportation Research Part E: Logistics and Transportation Review, 39(6), 459-471.

Grammenos, C. T., Nomikos, N. K., Papapostolou, N. C. (2008). Estimating the probability of default for shipping high yield bond issues. Transportation Research Part E: Logistics and Transportation Review, 44(6), 11231138.

Grammenos, C. T., Papapostolou, N. C. (2012a). Ship finance: US public equity markets. In W. K. Talley (Ed.), The Blackwell Companion to Maritime Economics (pp. 392-416): Blackwell Publishing.

Grammenos, C. T., Papapostolou, N. C. (2012b). US shipping initial public offerings: Do prospectus and market information matter? Transportation Research Part E: Logistics and Transportation Review, 48(1), 276-295.

Grammenos, Th. C., Marcoulis, N. S. (1996). Shipping initial public offerings: a cross-country analysis. In M. Levis (Ed.), Empirical Issues in Raising Equity Capital (pp. 379-400): Elsevier.

Greenwood, R., Hanson, S. G. (2015). Waves in ship prices and investment. Quarterly Journal of Economics, 130(1), 55-109.

Grelck, M. B., Prigge, S., Tegtmeier, L., Topalov, M. (2009). Diversification properties of investments in shipping. The Journal of Alternative Investments, 12(1), 55-74.

Guenther, D. A., Rosman, A. J. (1994). Differences between COMPUSTAT and CRSP SIC codes and related effects on research. Journal of Accounting and Economics, 18(1), 115-128.

Haigh, M. S. (2000). Cointegration, unbiased expectations and forecasting in the BIFFEX freight futures market, Journal of Futures Markets, 20, 545-571.

Haigh, M. S., Holt, M. T. (2002). Hedging foreign currency, freight and commodity futures portfolios, Journal of Futures Markets, 22(12), $1205-1221$.

Haralambides, H. E. (1992). Freight futures trading and shipowners expectations, Conference Proceedings, 6th World Conference on Transport Research, Lyon, France: Les Presses De L’Imprimerie Chirat, 2, 1411-1422.

Harwood, S. (2006), Shipping Finance, 3rd Edition, Euromoney Institutional Investor Plc., London

Heaver, T., Meersman, H., Moglia, F., Van de Voorde, E. (2000). Do mergers and alliances influence European shipping and port competition? Maritime Policy \& Management, 27(4), 363-373.

Helwege, J., Huang, J.-Z., Wang, Y. (2014). Liquidity effects in corporate bond spreads, Journal of Banking and Finance, 45, 105-116.

Ho, D. C., Au, K., Newton, E. (2002). Empirical research on supply chain management: a critical review and recommendations. International Journal of Production Research, 40(17), 4415-4430.

Jensen, M. C. (1986). Agency costs of free cash flow, corporate finance, and takeovers. The American Economic Review, 76(2), 323-329

Jensen, M. C., Meckling, W. H. (1976). Theory of the firm: Managerial behavior, agency costs and ownership structure. Journal of financial Economics, 3(4), 305-360.

Jia, C., Ritter, J. R., Xie, Z. Zhang, D. (2017). Pre-IPO Analyst Coverage: Hype or Information Production? December 9, 2017). Available at SSRN: https://ssrn.com/abstract=3086114.

Jiménez, G., Saurina, J. (2004). Collateral, type of lender and relationship banking as determinants of credit risk. Journal of Banking and Finance, 28(9), 2191-212.

John, K., Senbet, L. W. (1998). Corporate governance and board effectiveness. Journal of Banking \& Finance, 22(4), 371-403.

Johns, M., Sturm, C. (2015). The German KG system. In O. Schinas, M. Johns, C. Grau (Eds.). HSBA Handbook on Ship Finance: Berlin, Springer.

Jørgensen, P. L., De Giovanni, D. (2010). Time charters with purchase options in shipping: Valuation and risk management. Applied Mathematical Finance, 17(5), 399-430. 
Kalouptsidi, M. (2014). Time to build and fluctuations in bulk shipping. The American Economic Review, 104(2), 564-608.

Kang, H.-W., Wang, G. W., Bang, H.-S., Woo, S.-H. (2016). Economic performance and corporate financial management of shipping firms. Maritime Economics \& Logistics, 18(3), 317-330.

Kaplan, S. N., Schoar, A. (2005). Private equity performance: Returns, persistence, and capital flows. The Journal of Finance, 60(4), 1791-1823.

Kavussanos, M. G. (1996a). Comparisons of volatility in the dry-cargo ship sector: Spot versus time charters, and smaller versus larger vessels. Journal of Transport Economics and Policy, 67-82.

Kavussanos, M. G. (1996b) 'Price risk modelling of different size vessels in the tanker industry using Autoregressive Conditional Heteroskedasticity (ARCH) models', The Logistics and Transportation Review, 32(2), 161-176.

Kavussanos, M. G. (1997). The dynamics of time-varying volatilities in different size second-hand ship prices of the dry-cargo sector. Applied Economics, 29(4), 433-443.

Kavussanos, M. G. (2002). Business Risk Measurement and Management in the Cargo Carrying Sector of the Shipping Industry. In The Handbook of Maritime Economics and Business, Lloyds of London Press, London, Chapter 30, 661-692.

Kavussanos, M. G. (2003). Time varying risks among segments of the tanker freight markets. Maritime Economics \& Logistics, 5(3), 227-250.

Kavussanos, M. G. (2010). Business Risk Measurement and Management in the Cargo Carrying Sector of the Shipping Industry - An Update, In The Handbook of Maritime Economics and Business, Lloyds of London Press, London, Chapter 25, 709-743.

Kavussanos, M. G., Alizadeh, A. H. (2001). Seasonality patterns in dry bulk shipping spot and time charter freight rates. Transportation Research Part E: Logistics and Transportation Review, 37(6), 443-467.

Kavussanos, M. G., Dimitrakopoulos, D. N. (2007). Value at risk models in dry bulk ocean freight rates, Conference Proceedings, International Workshop in Economics and Finance, Tripolis, Greece, 14-16 June 2007.

Kavussanos, M. G., Dimitrakopoulos, D. N. (2011). Market risk model selection and medium-term risk with mimited data: Application to ocean tanker freight markets, International Review of Financial Analysis, 20, 258-268.

Kavussanos, M. G., Juell-Skielse, A., Forrest, M. (2003). International comparison of market risks across shippingrelated industries. Maritime Policy \& Management, 30(2), 107-122.

Kavussanos, M. G., Marcoulis, S. N. (1997a). Risk and return of US water transportation stocks over time and over bull and bear market conditions. Maritime Policy \& Management, 24(2), 145-158.

Kavussanos, M. G., Marcoulis, S. N. (1997b). The stock market perception of industry risk and microeconomic factors: The case of the US water transportation industry versus other transport industries. Transportation Research Part E: Logistics and Transportation Review, 33(2), 147-158.

Kavussanos, M. G., Marcoulis, S. N. (1998). Beta comparisons across industries - A water transportation industry perspective. Maritime Policy \& Management, 25(2), 175-184.

Kavussanos, M. G., Marcoulis, S. N. (2000a). The stock market perception of industry risk and macroeconomic factors: the case of the US water and other transportation stocks. International Journal of Maritime Economics, 2(3), 235-256.

Kavussanos, M. G., Marcoulis, S. N. (2000b). The stock market perception of industry risk through the utilisation of a general multifactor model. International Journal of Transport Economics/Rivista Internazionale di Economia dei Trasporti, 77-98.

Kavussanos, M. G., Marcoulis, S. N. (2001). Risk and return in transportation and other US and global industries, Kluwer Academic Publishers.

Kavussanos, M. G., Nomikos, N. K. (1999). The forward pricing function of the shipping freight futures market, Journal of Futures Markets, 19(3), 353-376.

Kavussanos, M. G., Nomikos, N. K. (2000a). Hedging in the freight futures market, Journal of Derivatives, Fall, 41-58.

Kavussanos, M. G., Nomikos, N. K. (2000b). Futures hedging when the structure of the underlying asset changes: The case of the BIFFEX contract, Journal of Futures Markets, 20, 775-801.

Kavussanos, M. G., Nomikos, N. K. (2000c). Constant vs. time-varying hedge ratios and hedging efficiency in the BIFFEX market, Transportation Research Part E: Logistics and Transportation Review, 36, 229-248.

Kavussanos, M. G., Nomikos, N. K. (2003). Price discovery, causality and forecasting in the freight futures market, Review of Derivatives Research, 6, 203-230.

Kavussanos, M. G., Tsouknidis, D. A. (2014). The determinants of credit spreads changes in global shipping bonds. Transportation Research Part E: Logistics and Transportation Review, 70, 55-75.

Kavussanos, M. G., Tsouknidis, D. A. (2016). Default risk drivers in shipping bank loans. Transportation Research Part E: Logistics and Transportation Review, 94, 71-94.

Kavussanos, M. G., Visvikis, I. D. (2004). Market interactions in returns and volatilities between spot and forward shipping freight markets. Journal of Banking \& Finance, 28(8), 2015-2049. 
Kavussanos, M. G., Visvikis, I. D. (2006a). Derivatives and Risk Management in Shipping. UK: Witherbys Publishing \& Seamanship International.

Kavussanos, M. G., Visvikis, I. D. (2006b). Shipping freight derivatives: a survey of recent evidence. Maritime Policy \& Management, 33(3), 233-255.

Kavussanos, M. G., Visvikis, I. D. (2007). Derivatives in freight markets, Special Report Commissioned by Lloyd's Shipping Economist, Informa Business, London.

Kavussanos, M. G., Visvikis, I. D. (2008). Freight derivatives and risk management: A review. In H. Geman (Eds.), Risk Management in Commodity Markets: From Shipping to Agriculturals and Energy: John Wiley \& Sons Ltd., UK.

Kavussanos, M. G., Visvikis, I. D. (2010). The Hedging performance of the Capesize forward freight market, In K. P. B. Cullinane (Eds.), The International Handbook of Maritime Economics and Business: Edward Elgar Publishing.

Kavussanos, M. G., Visvikis, I. D. (2011). Theory and practice of shipping freight derivatives. London: Risk Books a Division of Incisive Media Financial Publishing.

Kavussanos, M. G., Visvikis, I. D. (2014). Shipping freight derivatives: Practical examples and applications. In J. $\mathrm{Xu}$ (Eds.), Contemporary Marine and Maritime Policy: Nova Science Publishers, NY.

Kavussanos, M. G., Visvikis, I. D. (2016). The International Handbook of Shipping Finance: Theory and Practice. London: Palgrave Macmillan Publishers.

Kavussanos, M. G., Visvikis, I. D., Batchelor, R. (2004a). Over-the-counter forward contracts and spot price volatility in shipping, Transportation Research Part E: Logistics and Transportation Review, 40(4), 273-296.

Kavussanos, M. G., Visvikis, I. D., Dimitrakopoulos, D. N. (2010). Information linkages between Panamax freight derivatives and commodity derivatives markets, Maritime Economics and Logistics, 12(1), 91-110.

Kavussanos, M. G., Visvikis, I. D., Dimitrakopoulos, D. N. (2014a). Economic spillovers between related derivatives markets: The case of commodity and freight markets, Transportation Research Part E: Logistics and Transportation Review, 68, 79-102.

Kavussanos, M. G., Visvikis, I. D., Dimitrakopoulos, D. N. (2014b). Risk management in the shipping industry, In A. Roncoroni, G. Fusai, M. Cummins (Eds.), The Handbook of Multi-Commodity Markets and Products: Structuring, Trading and Risk Management: John Wiley \& Sons Inc.

Kavussanos, M. G., Visvikis, I. D., Goulielmou, M. A. (2007). An investigation of the use of risk management and shipping derivatives: The case of Greece, International Journal of Transport Economics, XXXIV(1), 49-68.

Kavussanos, M. G., Visvikis, I. D., Menachof, D. A. (2004b). The unbiasedness hypothesis in the freight forward market: Evidence from cointegration tests, Review of Derivatives Research, 7(3), 241-266.

Koekebakker, S., Adland, R. (2004). Modelling forward freight rate dynamics - Empirical evidence from time charter rates, Maritime Policy \& Management, 31(4), 319-336.

Koekebakker, S., Adland, R., Sødal, S. (2007). Pricing freight rate options, Transportation Research Part E: Logistics and Transportation Review, 43(5), 535-548.

Koufopoulos, D. N., Lagoudis, I. N., Theotokas, I. N., Syriopoulos, T. C. (2010). Corporate governance and board practices by Greek shipping management companies. Corporate Governance: The International Journal of Business in Society, 10(3), 261-278.

Kraus, A., Litzenberger, R. H. (1973). A state-preference model of optimal financial leverage. The Journal of Finance, 28(4), 911-922.

Kroll, M., Walters, B. A., Wright, P. (2008). Board vigilance, director experience, and corporate outcomes. Strategic Management Journal, 29(4), 363-382.

Kuo, C.-C., Chou, H.-C., Chang, C.-C. (2016), Exploring risk-return relations in dry bulk shipping, International Journal of Shipping and Transport Logistics, 8(4), 488-506.

Kyriakou, I., Pouliasis, P. K., Papapostolou, N. C., Andriosopoulos, K. (2017a). Freight derivatives pricing for decoupled mean-reverting diffusion and jumps, Transportation Research Part E: Logistics and Transportation Review, 108, 80-96.

Kyriakou, I., Pouliasis, P. K., Papapostolou, N. C., Nomikos, N. K. (2017b). Income uncertainty and the decision to invest in bulk shipping. European Financial Management. doi: 10.1111/eufm.12132.

Lai, V. S., Trigeorgis, L. (1995). The strategic capital budgeting process: a review of theories and practice. In L. Trigeorgis (Ed.), Real Options in Capital Investment: Models, Strategies, and Applications (pp. 69-86): Praeger Publishers.

Lau, Y.-Y., Ducruet, C., Ng, A. K. Y., Fu, X. (2017). Across the waves: a bibliometric analysis of container shipping research since the 1960s. Maritime Policy \& Management, 44(6), 667-684.

Lau, Y.-Y., Ng, A. K., Fu, X., Li, K. X. (2013). Evolution and research trends of container shipping. Maritime Policy \& Management, 40(7), 654-674.

Lee, C-Y., Song, D.P. (2017). Ocean container transport in global supply chains: Overview and research opportunities, Transportation Research Part B: Methodological, 95, 442-474.

Lee, K. R., Pak, M.-S. (2018). Multi-criteria analysis of decision-making by international commercial banks for providing shipping loans. Maritime Policy and Management, DOI: 10.1080/03088839.2018.1448476. 
Leggate, H. (2000). A European perspective on bond finance for the maritime industry. Maritime Policy \& Management, 27(4), 353-362.

Lemmon, M. L., Roberts, M. R., Zender, J. F. (2008). Back to the beginning: persistence and the cross-section of corporate capital structure. The Journal of Finance, 63(4), 1575-1608.

Li, K. X., Qi, G., Shi, W., Yang, Z., Bang, H.-S., Woo, S.-H., Yip. T. L (2014). Spillover effects and dynamic correlations between spot and forward tanker freight markets, Maritime Policy \& Management 41(7), 683696.

Li, Y. (2006). The pros and cons of leasing in ship financing. WMU Journal of Maritime Affairs, 5(1), 61-74.

Lintner, J. (1965). The valuation of risk assets and the selection of risky investments in stock portfolios and capital budgets. The Review of Economics and Statistics, 13-37.

Loughran, T., Ritter, J.R., (1995). The new issues puzzle. Journal of Finance, 50 (1), 23-51.

Lozinskaia, A., Merikas, A., Merika, A., Penikas, H. (2017). Determinants of the probability of default: the case of the internationally listed shipping corporations. Maritime Policy \& Management, 44(7), 837-858.

Lu, J., Wei, F., Want, H. (2007). Value-at-risk on dry bulk shipping freight index, Conference Proceedings, Annual Conference of International Association of Maritime Economists, 4-6 July, Athens, Greece.

Lyridis, D. Zacharioudakis, P. Ioardanis, S., Daleziou, S. (2013). Freight forward agreement time series modelling based on artificial neural network models, Journal of Mechanical Engineering, 59, 511-516.

Mayr, T. P., Tamvakis, M. N. (1999). The dynamic relationships between paper petroleum refining and physical trade of crude oil into the United States, Maritime Policy \& Management, 26, 127-136.

McBain, M. L., Krause, D. S. (1989). Going public: The impact of insiders' holdings on the price of initial public offerings. Journal of Business Venturing, 4(6), 419-428.

McLaney, E., Pointon, J., Thomas, M., Tucker, J. (2004). Practitioners' perspectives on the UK cost of capital. The European Journal of Finance, 10(2), 123-138.

Mentzer, J. T., Kahn, K. B. (1995). A framework of logistics research. Journal of Business Logistics, 16(1), 231.

Merika, A. A., Theodoropoulou, S., Triantafyllou, A., Laios, A. (2015). The relationship between business cycles and capital structure choice: The case of the indernational shipping industry. The Journal of Economic Asymmetries, 12, 92-99.

Merikas, A. G., Merika, A. A., Koutroubousis, G. (2008). Modelling the investment decision of the entrepreneur in the tanker sector: choosing between a second-hand vessel and a newly built one. Maritime Policy \& Management, 35(5), 433-447.

Merikas, A. G., Polemis, D., Triantafyllou, A. (2011). Mergers and acquisitions in the shipping industry. Journal of Applied Business Research, 27(4), 9-22.

Merikas, A., Gounopoulos, D., Karli, C. (2010). Market performance of US-listed shipping IPOs. Maritime Economics \& Logistics, 12(1), 36-64.

Merikas, A., Gounopoulos, D., Nounis, C. (2009). Global shipping IPOs performance. Maritime Policy \& Management, 36(6), 481-505.

Merton, R. C. (1973). An intertemporal capital asset pricing model. Econometrica: Journal of the Econometric Society, 867-887.

Miller, E. M. (1977). Risk, uncertainty, and divergence of opinion. The Journal of Finance, 32(4), 1151-1168.

Mitroussi, K., Abouarghoub, W., Haider, J. J., Pettit, S. J., Tigka, N. (2016). Performance drivers of shipping loans: An empirical investigation. International Journal of Production Economics, 171, 438-452.

Miyashita, K. (1982). A quarterly econometric analysis of ship investment planning behaviour in the world bulk carrier industry. Maritime Policy \& Management, 9(2), 115-133.

Modigliani, F., Miller, M. H. (1958). The cost of capital, corporation finance and the theory of investment. The American Economic Review, 48(3), 261-297.

Mossin, J. (1966). Equilibrium in a capital asset market. Econometrica: Journal of the Econometric Society, 768783.

Myers, S. C., Majluf, N. S. (1984). Corporate financing and investment decisions when firms have information that investors do not have. Journal of Financial Economics, 13(2), 187-221.

Nam, H. J., An, Y. H. (2017). Default risk and firm value of shipping \& logistics firms in Korea. The Asian Journal of Shipping and Logistics, 33(2), 61-65.

$\mathrm{Ng}$, A. K. (2013). The evolution and research trends of port geography. The Professional Geographer, 65(1), 65-86.

Nomikos, N. K., Doctor, K. (2013) Economic significance of market timing rules in the Forward Freight Agreement markets, Transportation Research Part E: Logistics and Transportation Review, 52, 77-93.

Nomikos, N. K., Kyriakou, I., Papapostolou, N. C., Pouliasis, P. K. (2013). Freight options: Price modelling and empirical analysis. Transportation Research Part E: Logistics and Transportation Review, 51, 82-94

Nomikos, N., Alizadeh, A. H. (2002). Risk management in the shipping industry: Theory and practice. In Grammenos, C.T. (Ed.), The Handbook of Maritime Economics and Business (pp. 693-730). London: LLP Professional Publishing.

Nomikos, N., Alizadeh, A. H. (2010). Managing freight rate risk using freight derivatives: An overview of the evidence. In Grammenos, C.T. (Ed.), The Handbook of Maritime Economics and Business London: Lloyd's List. 
Pallis, A. A., Vitsounis, T. K., De Langen, P. W. (2010). Port economics, policy and management: Review of an emerging research field. Transport Reviews, 30(1), 115-161.

Pallis, A. A., Vitsounis, T. K., De Langen, P. W., Notteboom, T. E. (2011). Port economics, policy and management: Content classification and survey. Transport Reviews, 31(4), 445-471.

Panayides, P. M. (2006). Maritime logistics and global supply chains: Towards a research agenda. Maritime Economics \& Logistics, 8(1), 3-18.

Paine, F. (1990), The Financing of Ship Acquisitions, Fairplay Publications.

Panayides Ph. M. (2002), Recent Developments in International Shipping Finance, London: Informa Publications.

Panayides, P. M., Gong, X. (2002). The stock market reaction to merger and acquisition announcements in liner shipping. International Journal of Maritime Economics, 4(1), 55-80.

Panayides, P. M., Lambertides, N., Cullinane, K. P. B. (2013). Liquidity risk premium and asset pricing in US water transportation. Transportation Research Part E: Logistics and Transportation Review, 52, 3-15.

Papapostolou, N. C., Nomikos, N. K., Pouliasis, P. K., Kyriakou, I. (2014). Investor sentiment for real assets: The case of dry bulk shipping market. Review of Finance, 18(4), 1507-1539.

Papapostolou, N. C., Pouliasis, P. K., Kyriakou, I. (2017). Herd behavior in the drybulk market: an empirical analysis of the decision to invest in new and retire existing fleet capacity. Transportation Research Part E: Logistics and Transportation Review, 104, 36-51.

Pastra, A. S., Koufopoulos, D. N., Gkliatis, I. P. (2015). Board characteristics and the presence of women on the board of directors: The case of the Greek shipping sector. In M. Kitada M., E. Williams, L. Froholdt (Eds.) Maritime Women: Global Leadership. WMU Studies in Maritime Affairs (vol 3. pp. 35-54): Springer, Berlin.

Petersen, M. A. (2009). Estimating standard errors in finance panel data sets: Comparing approaches. Review of Financial Studies, 22(1), 435-480.

Peterson, P. P., Fabozzi, F. J. (2002). Capital budgeting: theory and practice (Vol. 10): John Wiley \& Sons.

Phalippou, L., Gottschalg, O. (2009). The performance of private equity funds. Review of Financial Studies, 22(4), 1747-1776.

Pires, F. C., Assis, L. F., Souza, C. M. (2005). An analysis of the Brazilian ship financing system. Maritime Policy \& Management, 32(3), 209-226.

Pouliasis, P. K., Papapostolou, N. C., Kyriakou, I., Visvikis, I. D. (2017). Tail risk and the asset allocation problem in shipping equity portfolios, Conference Proceedings, Annual Conference of International Association of Maritime Economistis, 27-30 June, Kyoto, Japan.

Pribor, J., Lind, C. S. (2016). Public and Private Equity Markets. In M. G. Kavussanos, I. D. Visvikis (Eds.), The International Handbook of Shipping Finance: Theory and Practice (pp. 169-189): Palgrave Macmillan.

Prokopczuk, M. (2011). Pricing and hedging in the freight futures market, Journal of Futures Markets, 31, 440-464.

Randøy, T., Down, J., Jenssen, J. (2003). Corporate governance and board effectiveness in maritime firms. Maritime Economics \& Logistics, 5(1), 40-54.

Rau, P., Spinler, S. (2016). Investment into container shipping capacity: A real options approach in oligopolistic competition. Transportation Research Part E: Logistics and Transportation Review, 93, 130-147.

Renneboog, L., Simons, T., Wright, M. (2007). Why do public firms go private in the UK? The impact of private equity investors, incentive realignment and undervaluation. Journal of Corporate Finance, 13(4), 591-628.

Richardson, S., Sloan, R., Soliman, M., Tuna, I. (2006). The implications of accounting distortions and growth for accruals and profitability. The Accounting Review, 81(3), 713-743

Ritter, J.R., Welch, I., (2002). A review of IPO activity, pricing, and allocations. The Journal of Finance. 57 (4), 1795-1828.

Rodrigue, J. P., Notteboom, T. E., Pallis, A. A. (2011). The financialization of the port and terminal industry: revisiting risk and embeddedness. Maritime Policy \& Management. 38(2), 191-213.

Roll, R. (1984). A simple implicit measure of the effective bid-ask spread in an efficient market. The Journal of Finance, 39(4), 1127-1139.

Ross, S. A. (1976). The arbitrage theory of capital asset pricing. Journal of Economic Theory, 13(3), 341-360.

Rousos, E.-P., Lee, B. S. (2012). Multicriteria analysis in shipping investment evaluation. Maritime Policy \& Management, 39(4), 423-442.

Samitas, A. G., Kenourgios, D. F. (2007). Impact of mergers and acquisitions on stock returns of tramp shipping firms. International Journal of Financial Services Management, 2(4), 327-343.

Samitas, A. G., Tsakalos, I. (2010). Hedging effectiveness in the shipping industry during financial crises, International Journal of Financial Markets and Derivatives, 1(2), 196-212.

Santos, J. A. (2011). Bank corporate loan pricing following the subprime crisis. Review of Financial Studies, 24(6), 1916-1943.

Satta, G. (2017). Initial public offerings in the port industry: exploring the determinants of underpricing. Maritime Policy \& Management, 44(8), 1012-1033.

Satta, G., Notteboom, T., Parola, F., Persico, L. (2017). Determinants of the long-term performance of initial public offerings (IPOs) in the port industry. Transportation Research Part A: Policy and Practice, 103, 135-153.

Scarsi, R. (2007). The bulk shipping business: market cycles and shipowners' biases. Maritime Policy \& Management, 34(6), 577-590. 
Schinas, O., Grau, C., Johns, M. (2015). HSBA handbook on ship finance: Springer.

Sharpe, W. F. (1964). Capital asset prices: A theory of market equilibrium under conditions of risk. The Journal of Finance, 19(3), 425-442.

Shi, W., Li, K. X. (2017). Themes and tools of maritime transport research during 2000-2014. Maritime Policy \& Management, 44(2), 151-169.

Shleifer, A., Vishny, R. W. (1997). A survey of corporate governance. The Journal of Finance, 52(2), 737-783.

Simic, A. K., Lauenstein, P., Prigge, S. (2016). Valuation efficiency of secondary markets for formerly illiquid assets: The case of German KG ship funds. Multinational Finance Journal, 20(2), 127-179.

Sloggett, J. E. (1998), Financing Ships and Mobile Offshore Installations, Fairplay Publications.

Sødal, S., Koekebakker, S., Adland, R. (2008). Market switching in shipping - A real option model applied to the valuation of combination carriers. Review of Financial Economics, 17(3), 183-203.

Sødal, S., Koekebakker, S., Adland, R. (2009). Trading rules with analytical ship valuation under stochastic freight rates, Applied Economics, 41(22), 2793-2807.

Steenken, D., Voß, S., Stahlbock, R. (2004). Container terminal operation and operations research-a classification and literature review. OR Spectrum, 26(1), 3-49.

Stokes, P. (1997), Ship Finance: Credit Expansion, and the Boom Bust Cycle, LLP Professional Publishing

Stopford, M. (2009). Maritime Economics. New York: Routledge.

Strandenes, S. (1984). Price determination in the time charter and second hand markets. Center for Applied Research, Norwegian School of Economics and Business Administration, Working Paper MU, 6.

Sun, X., Liu, H., Zheng, H., Chen, S. (2018). Combination hedging strategies for crude oil and dry bulk freight rates on the impacts of dynamic cross-market interaction. Maritime Policy \& Management, 45(2), 174-196.

Syriopoulos, T. (2007). Financing Greek Shipping: Modern Instruments, Methods and Markets, In A. Pallis (Eds.), Research in Transportation Economics vol. 1, Maritime Transport: The Greek Paradigm, Chapter 6: Elsevier.

Syriopoulos, T., Theotokas, I. (2007). Value creation through corporate destruction? Corporate governance in shipping takeovers. Maritime Policy \& Management, 34(3), 225-242.

Syriopoulos, T., Tsatsaronis, M. (2011). The corporate governance model of the shipping firms: financial performance implications. Maritime Policy \& Management, 38(6), 585-604.

Syriopoulos, T., Tsatsaronis, M. (2012). Corporate governance mechanisms and financial performance: CEO duality in shipping firms. Eurasian Business Review, 2(1), 1-30.

Tezuka, K., Ishii, M., Ishizaka, M. (2012). Relationship between CAPM- $\beta$ and market changes in the Japanese liner shipping industry. Maritime Policy \& Management, 39(3), 297-319.

Theotokas, I. (2007). On top of world shipping: Greek shipping companies' organization and management. Research in Transportation Economics, 21, 63-93.

Thuong, L. T., Vischer, S. L. (1990). The hedging effectiveness of dry-bulk freight rate futures, Transportation Journal, 29, 58-65.

Tsionas, M. G., Merikas, A. G., Merika, A. A. (2012). Concentrated ownership and corporate performance revisited: The case of shipping. Transportation Research Part E: Logistics and Transportation Review, 48(4), 843-852.

Tsouknidis, D. A. (2016). Dynamic volatility spillovers across shipping freight markets. Transportation Research Part E: Logistics and Transportation Review, 91, 90-111.

Tvedt, J. (1997). Valuation of VLCCs under income uncertainty. Maritime Policy \& Management, 24(2), $159-174$.

Tvedt, J. (1998). Valuation of a European futures option in the BIFFEX market, Journal of Futures Markets, 18(2), 167-175.

Wacker, J. G. (1998). A definition of theory: research guidelines for different theory-building research methods in operations management. Journal of Operations Management, 16(4), 361-385.

Walker, J. A., Murphy, J. B. (2001). Implementing the North American industry classification system at BLS. Monthly Labor Review, 124(12), 15-21.

Wang, X., Teo, C-C. (2013). Integrated hedging and network planning for container shipping's bunker fuel management, Maritime Economics and Logistics, 15, 172-196.

Woo, S.-H., Pettit, S. J., Kwak, D.-W., Beresford, A. K. (2011). Seaport research: A structured literature review on methodological issues since the 1980s. Transportation Research Part A: Policy and Practice, 45(7), 667-685.

Woo, S.-H., Pettit, S., Beresford, A., Kwak, D.-W. (2012). Seaport research: A decadal analysis of trends and themes since the 1980s. Transport Reviews, 32(3), 351-377.

Xu, J. J., Yip, T. L. (2012). Ship investment at a standstill? An analysis of shipbuilding activities and policies. Applied Economics Letters, 19(3), 269-275.

Yeo, H.-J. (2013). Geography of mergers and acquisitions in the container shipping industry. The Asian Journal of Shipping and Logistics, 29(3), 291-314.

Yin, J., Luo, M., Fan, L. (2017). Dynamics and interactions between spot and forward freights in the dry bulk shipping market, Maritime Policy \& Management, 44(2), 271-288.

Yolland, J. B. (1979). Ship finance and Euro-markets. Maritime Policy \& Management, 6(3), 175-181.

Zhang, J., Zeng, Q., Zhao, X. (2014). Forecasting spot freight rates based on forward freight agreement and time charter contract, Applied Economics, 46, 3639-3648. 
Zavgren, C. V. (1983). The prediction of corporate failure: the state of art. Journal of Accounting Literature, 2, 138.

Zheng, S., Negenborn, R. R. (2017). Terminal investment timing decisions in a competitive setting with uncertainty using a real option approach. Maritime Policy \& Management, 44(3), 392-411. 
Figure 1. Visualisation of Co-Authorship in the Shipping Finance Literature (1979-2018)

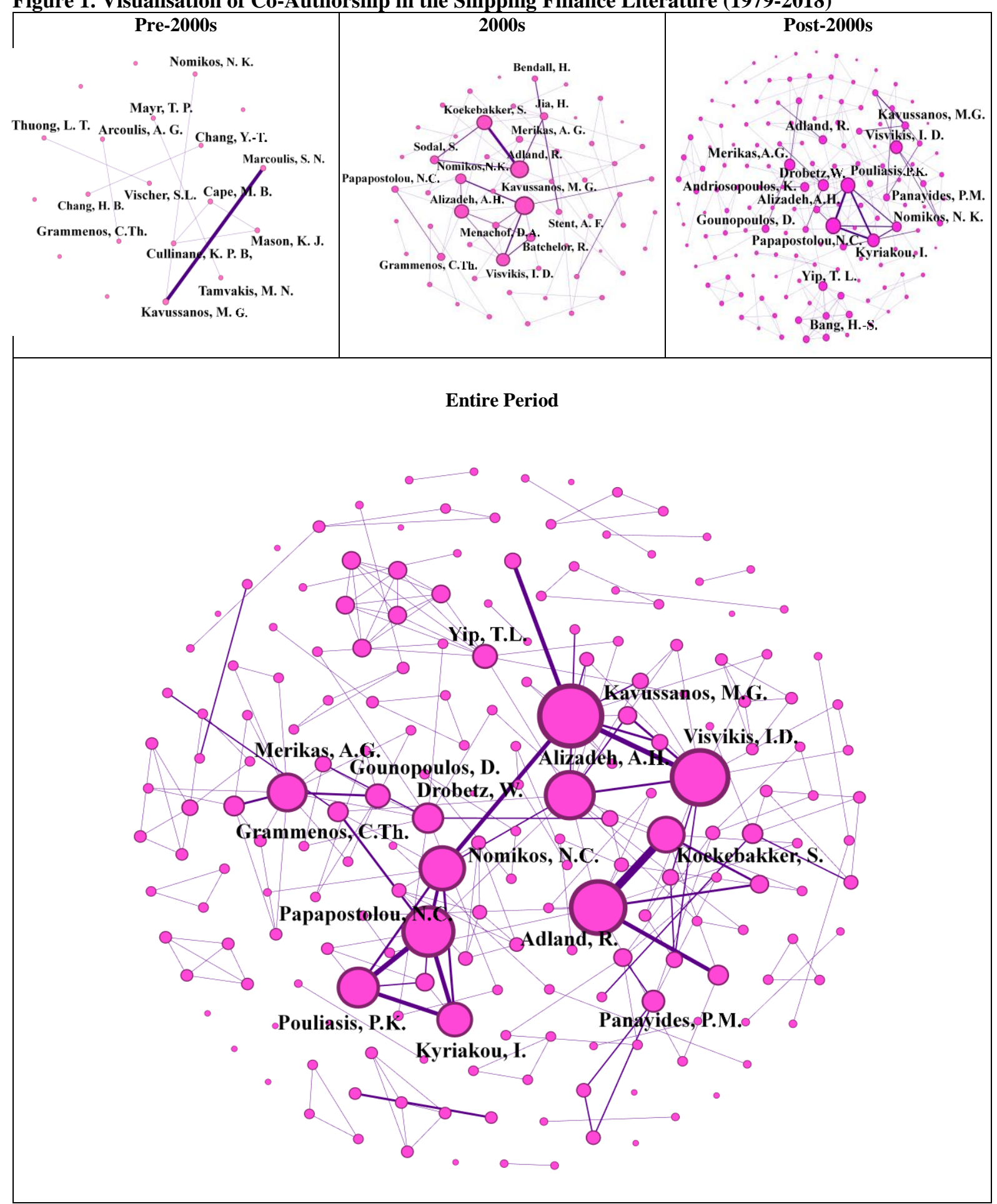


Figure 2. Sources of Capital in the Shipping Industry (2007-2017, in \$ billion)

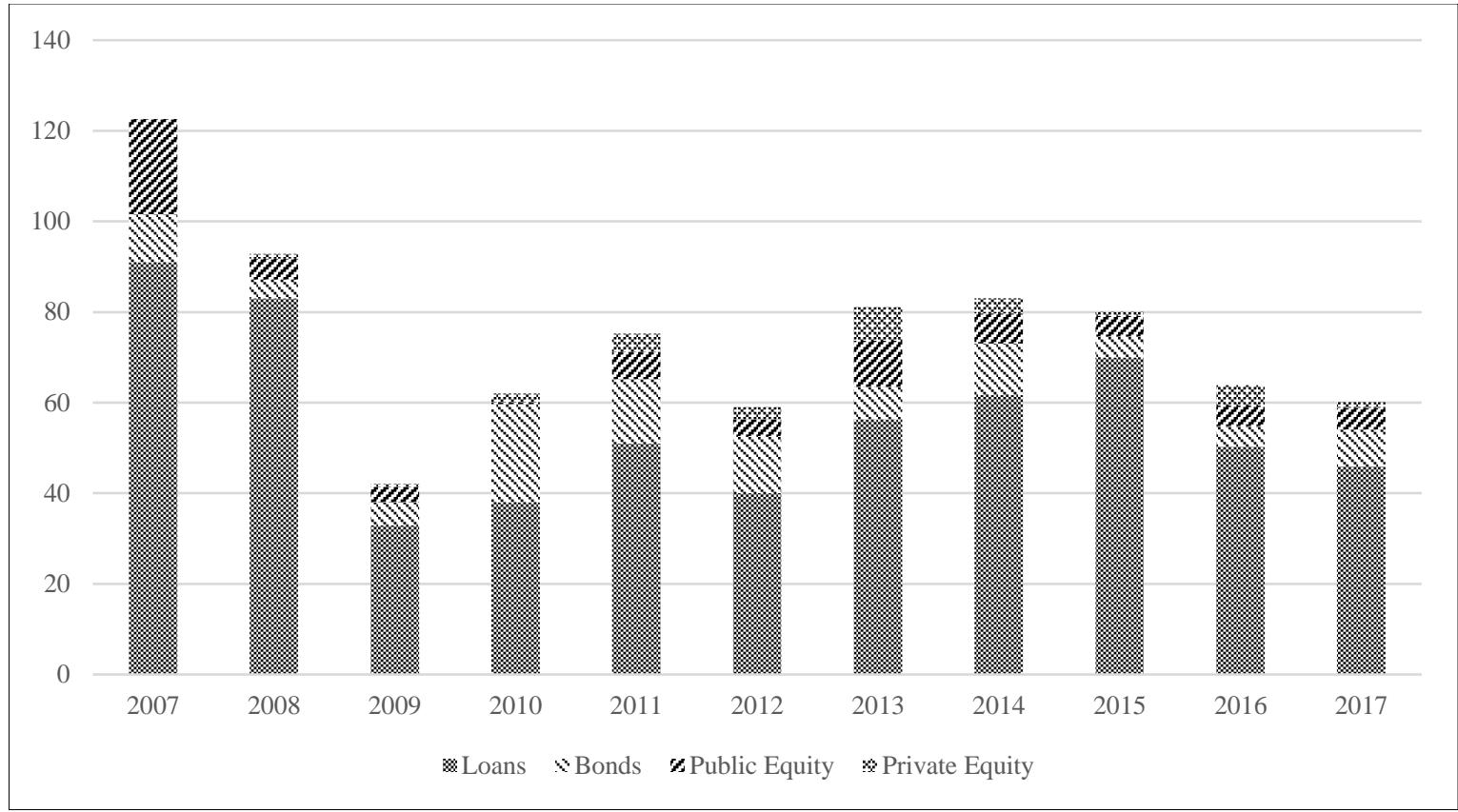

Data Sources: Marine Money International, Dealogic 
Table 1. List of Scholarly Journals Featuring Shipping Finance and Investment Articles 1979-2018 (paper counts)

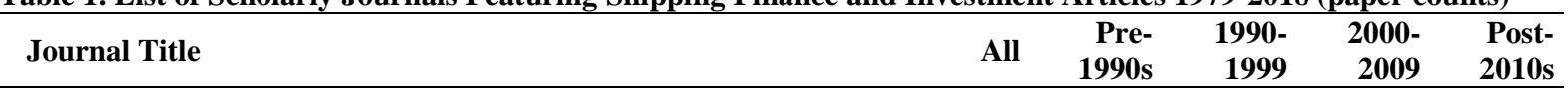

African Journal of Business Management

American Economic Review

Applied Economics

Applied Economics Letters

Applied Financial Economics

Applied Mathematical Finance

Asian Journal of Shipping and Logistics

Corporate Governance: The international journal of business in society

Empirical Economics

Energy Economics

Eurasian Business Review

European Financial Management

International Journal of Financial Markets and Derivatives

International Journal of Financial Services Management

International Journal of Forecasting

International Journal of Logistics Research and Applications

International Journal of Production Economics

International Journal of Shipping and Transport Logistics

International Journal of Theoretical and Empirical Finance

International Journal of Transport Economics

International Review of Financial Analysis

International Research in Economics and Finance

Journal of Applied Business Research

Journal of Banking and Finance

Journal of Derivatives

Journal of Derivatives \& Hedge Funds

Journal of Economic Asymmetries

Journal of Forecasting

Journal of Futures Markets

Journal of Islamic Thought and Civilisation

Journal of Mechanical Engineering

Journal of Multi-Criteria Decision Analysis

Journal of Transport Economics and Policy

Maritime Economics and Logistics

Maritime Policy and Management

Multinational Finance Journal

Quarterly Journal of Economics

Review of Derivatives Research

Review of Finance

Review of Financial Economics

The Journal of Alternative Investments

Transport Policy

Transportation

Transportation Journal

Transportation Research Part A: Policy and Practice

Transportation Research Part B: Methodological

Transportation Research Part E: Logistics and Transportation Review

WMU Journal of Maritime Affairs

Total

162

1

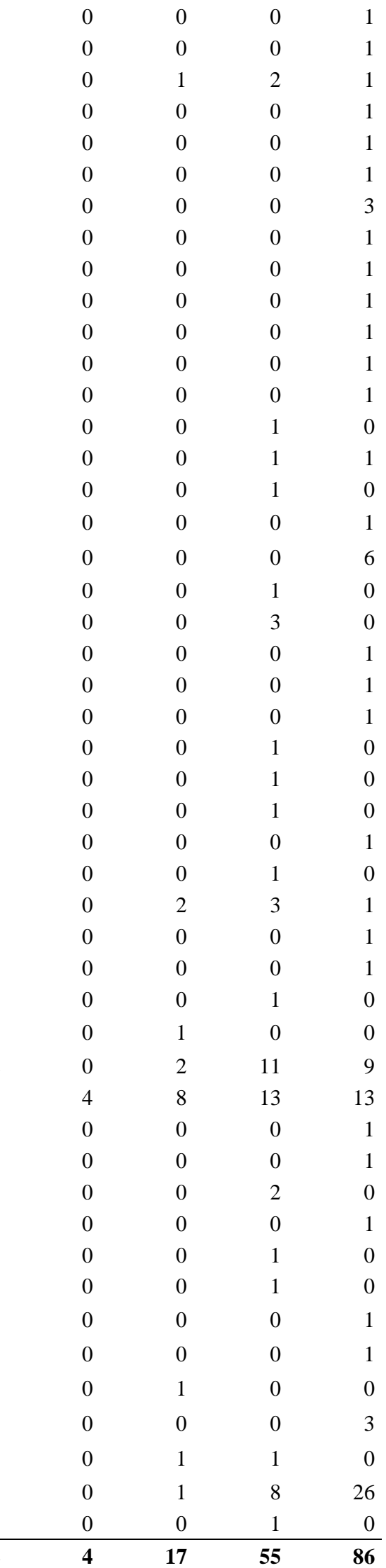


Table 2. Research Topics, Journal Disciplines and Regional Focus (paper counts)

\begin{tabular}{|c|c|c|c|c|c|}
\hline & All & $\begin{array}{r}\text { Pre- } \\
1990 s\end{array}$ & $\begin{array}{r}1990- \\
1999 \\
\end{array}$ & $\begin{array}{r}2000- \\
2009 \\
\end{array}$ & $\begin{array}{l}\text { Post- } \\
2000 s \\
\end{array}$ \\
\hline \multicolumn{6}{|l|}{ Panel A: Research Topics } \\
\hline Sources of Finance in Shipping and Capital Structure & 34 & 1 & 1 & 10 & 22 \\
\hline Shipping Investment and Valuation Methods & 61 & 3 & 6 & 22 & 30 \\
\hline Corporate Governance of Shipping Companies & 6 & 0 & 0 & 1 & 5 \\
\hline Risk Measurement and Management in Shipping & 61 & 0 & 10 & 22 & 29 \\
\hline
\end{tabular}

\section{Panel B: Journal Discipline}

\begin{tabular}{|c|c|c|c|c|c|}
\hline Maritime & 61 & 4 & 10 & 25 & 22 \\
\hline Transportation and Logistics & 57 & 0 & 4 & 13 & 40 \\
\hline Finance & 22 & 0 & 2 & 12 & 8 \\
\hline Economics & 11 & 0 & 1 & 2 & 8 \\
\hline Management & 5 & 0 & 0 & 1 & 4 \\
\hline Operations & 4 & 0 & 0 & 2 & 2 \\
\hline Engineering & 1 & 0 & 0 & 0 & 1 \\
\hline Sociology & 1 & 0 & 0 & 0 & 1 \\
\hline
\end{tabular}

Panel C: Regional Focus of the Research Topic

\begin{tabular}{|c|c|c|c|c|c|c|}
\hline \multirow[t]{10}{*}{ Country } & & 31 & 0 & 3 & 10 & 18 \\
\hline & U.S. & 18 & 0 & 3 & 6 & 9 \\
\hline & Greece & 4 & 0 & 0 & 1 & 3 \\
\hline & China & 2 & 0 & 0 & 1 & 1 \\
\hline & Germany & 2 & 0 & 0 & 0 & 2 \\
\hline & Japan & 2 & 0 & 0 & 0 & 2 \\
\hline & Brazil & 1 & 0 & 0 & 1 & 0 \\
\hline & South Korea & 1 & 0 & 0 & 0 & 1 \\
\hline & UK & 1 & 0 & 0 & 1 & 0 \\
\hline & Italy & 1 & 0 & 0 & 0 & 1 \\
\hline Region & & 7 & 0 & 1 & 6 & 0 \\
\hline Global & & 33 & 0 & 3 & 7 & 23 \\
\hline N/A & & 90 & 4 & 10 & 32 & 44 \\
\hline
\end{tabular}

Note: In Panel B, the journals included in each discipline are as following (in an alphabetical order): Maritime (Maritime Economics and Logistics, Maritime Policy and Management, WMU Journal of Maritime Affairs); Transportation and Logistics (Asian Journal of Shipping and Logistics, International Journal of Logistics Research and Applications, International Journal of Shipping and Transport Logistics, International Journal of Transport Economics, Journal of Transport Economics and Policy, Transportation Journal, Transport Policy, Transportation Research Part A: Policy and Practice, Transportation Research Part B: Methodological, Transportation Research Part E: Logistics and Transportation Review); Finance (Applied Financial Economics, Applied Mathematical Finance, European Financial Management, International Journal of Financial Markets and Derivatives, International Journal of Financial Services Management, International Journal of Theoretical and Empirical Finance, International Review of Financial Analysis, Journal of Banking and Finance, Journal of Derivatives, Journal of Derivatives and Hedge Funds, Journal of Futures Markets, Multinational Finance Journal, Review of Derivatives Research, Review of Finance, Review of Financial Economics, The Journal of Alternative Investments); Economics (American Economic Review, Applied Economics, Applied Economics Letters, Empirical Economics, Energy Economics, Quarterly Journal of Economics, International Research in Economics and Finance, Journal of Economic Asymmetries); Management and Business (African Journal of Business Management, Corporate Governance: The International Journal of Business in Society, Eurasian Business Review, Journal of Applied Business Research, Journal of Multi-Criteria Decision Analysis); Operations (International Journal of Forecasting, International Journal of Production Economics, Journal of Forecasting); Engineering (Journal of Mechanical Engineering); Sociology (Journal of Islamic Thought and Civilisation). 
Table 3. Methodological Issues (paper counts)

All Pre-1990s 1990-1999 2000-2009 Post-2000s

Panel A: Theory-building Types

\begin{tabular}{|c|c|c|c|c|c|c|}
\hline \multirow[t]{4}{*}{ Analytical - Total } & & 31 & 1 & 3 & 10 & 17 \\
\hline & Conceptual & 4 & 1 & 0 & 2 & 1 \\
\hline & Mathematical & 21 & 0 & 3 & 7 & 11 \\
\hline & Statistical & 6 & 0 & 0 & 1 & 5 \\
\hline \multirow[t]{4}{*}{ Empirical - Total } & & 131 & 3 & 14 & 45 & 68 \\
\hline & Experimental & 1 & 0 & 0 & 0 & 1 \\
\hline & Statistical & 124 & 1 & 14 & 43 & 66 \\
\hline & Case study & 6 & 2 & 0 & 2 & 2 \\
\hline
\end{tabular}

Panel B: Research Methods

\begin{tabular}{lrrrr} 
Economic Modelling & 122 & 1 & 13 & 40 \\
Mathematical Modelling & 21 & 0 & 3 & 7 \\
Survey & 9 & 0 & 1 & 5 \\
Case Study & 6 & 2 & 0 & 3 \\
Conceptual Work & 3 & 1 & 0 & 2 \\
\hline
\end{tabular}

Panel C: Data Analysis Techniques

\begin{tabular}{|c|c|c|c|c|c|}
\hline Regression & 47 & 1 & 6 & 11 & 29 \\
\hline Error Correction Model & 23 & 0 & 1 & 15 & 7 \\
\hline Real Option Modelling & 17 & 0 & 2 & 6 & 9 \\
\hline Descriptive & 14 & 3 & 1 & 6 & 4 \\
\hline Autoregressive Conditional Heteroscedasticity & 12 & 0 & 2 & 2 & 8 \\
\hline Event Study Analysis & 8 & 0 & 0 & 6 & 2 \\
\hline Simultaneous Equations Modelling & 5 & 0 & 0 & 0 & 5 \\
\hline Autoregressive Moving Average & 3 & 0 & 2 & 0 & 1 \\
\hline Analytical Hierarchy Process & 2 & 0 & 0 & 0 & 2 \\
\hline Efficient Frontier Analysis & 2 & 0 & 0 & 1 & 1 \\
\hline Principal Component Analysis & 2 & 0 & 0 & 1 & 1 \\
\hline Utilites Additives Discriminantes & 2 & 0 & 0 & 1 & 1 \\
\hline
\end{tabular}

Notes: In Panel C, data analysis techniques of the same modelling family are grouped under the same category. For example, regression incudes univariate, multivariate and logit models, options pricing includes both closed-form solutions and dynamic programming, and Autoregressive Conditional Heteroscedasticity (ARCH) includes also Generalised ARCH models. The 'Others' group includes cost-benefit analysis, regime switching and other techniques with only one paper count. 
Panel A: Authorship

\begin{tabular}{lrrrr} 
Average number of authors & 2.4 & 1 & 1.6 & 2.3 \\
Collaboration & 81 & 0 & 2 & 28 \\
International collaboration & 49 & 0 & 2 & 20 \\
Academic-market collaboration & 23 & 0 & 1 & 10 \\
\hline
\end{tabular}

\section{Panel B: Citation Statistics}

Shipping finance papers

\begin{tabular}{|c|c|c|c|c|c|}
\hline Average citations per article & 24.4 & 5.0 & 38.0 & 36.1 & 10.4 \\
\hline Annual average citations per article & 2.7 & 0.1 & 1.9 & 3.1 & 2.7 \\
\hline papers in the same volume or issue & & & & & \\
\hline Average citations per article & 38.8 & 9.5 & 39.4 & 62.5 & 17.4 \\
\hline Annual average citations per article & 4.4 & 0.3 & 2.0 & 5.1 & 4.7 \\
\hline
\end{tabular}

5.1

Notes: In Panel A, the three types of collaboration are determined in terms of institutions that individual authors are affiliated to in the year of publication. Collaboration indicates co-authorship between researchers from different institutions; International collaboration indicates co-authorship between researchers from institutions in different countries; and Academic-market collaboration indicates coauthorship between researchers from academic institutions and the industry/market practitioners. 
Table 5. Summary of Literature on Sources of Shipping Finance and Capital Structure (sorted by year of publication and names of authors)

\begin{tabular}{|c|c|c|c|c|}
\hline \multirow{2}{*}{ STUDY } & \multirow{2}{*}{ DESCRIPTION } & \multicolumn{2}{|c|}{ SAMPLE } & \multirow{2}{*}{ MAIN RESULTS } \\
\hline & & Observations & Period & \\
\hline Yolland (1979) & $\begin{array}{l}\text { Assessing the use of Eurodollars in } \\
\text { shipping finance }\end{array}$ & Descriptive study & - & $\begin{array}{l}\text { - Short-term Eurodollar deposits can be beneficial for long- } \\
\text { term ship lending }\end{array}$ \\
\hline $\begin{array}{l}\text { Grammenos and } \\
\text { Arkoulis (1999) }\end{array}$ & $\begin{array}{l}\text { Exploring the long-term } \\
\text { performance of shipping IPOs }\end{array}$ & 27 IPOs & $1987-1998$ & $\begin{array}{l}\text { - IPOs underperform stock indices by } 37 \% \text { based on } 24 \text {-month } \\
\text { Cumulative Abnormal Returns (CARs) } \\
\text { - Long-run performance is positively associated with shipping } \\
\text { market conditions and financial leverage at the time of the } \\
\text { IPO, and negatively with fleet age }\end{array}$ \\
\hline Leggate (2000) & $\begin{array}{l}\text { Investigation of the determinants of } \\
\text { bond spreads for a sample of } \\
\text { European shipping companies }\end{array}$ & $\begin{array}{l}33 \text { bond } \\
\text { issuances }\end{array}$ & $1997-2000$ & $\begin{array}{l}\text { - Credit ratings are negatively associated with bond coupons, } \\
\text { and positively with shipping market conditions }\end{array}$ \\
\hline $\begin{array}{l}\text { Cullinane and Gong } \\
\text { (2002) }\end{array}$ & $\begin{array}{l}\text { Investigation of the short-term } \\
\text { performance of Chinese } \\
\text { transportation IPOs }\end{array}$ & 84 IPOs & $1972-1998$ & $\begin{array}{l}\text { - IPOs are underpriced by } 70.76 \% \text { which is attributed to their } \\
\text { higher level of uncertainty }\end{array}$ \\
\hline Dimitras et al. (2002) & $\begin{array}{l}\text { Application of the UTADIS method } \\
\text { for constructing a credit evaluation } \\
\text { model of bank shipping loans }\end{array}$ & Case study & - & $\begin{array}{l}\text { - The following criteria along with their weights are found to } \\
\text { be relevant: quality of management }(33.97 \%) \text {, credit history } \\
\text { (19.59\%), financial characteristics }(12.35) \text {, fleet }(10.63 \%) \text {, } \\
\text { special proposal }(8.25 \%)\end{array}$ \\
\hline $\begin{array}{l}\text { Grammenos and } \\
\text { Arkoulis (2003) }\end{array}$ & $\begin{array}{l}\text { Investigation of factors affecting } \\
\text { shipping high yield bonds in the } \\
\text { U.S. }\end{array}$ & $\begin{array}{l}30 \text { bond } \\
\text { issues }\end{array}$ & 1993-1998 & $\begin{array}{l}\text { - Bond spreads of shipping companies are positively related to } \\
\text { issuer's financial leverage, and negatively to credit rating and } \\
\text { shipping market conditions }\end{array}$ \\
\hline Pires et al. (2005) & $\begin{array}{l}\text { An analysis of the effectiveness of } \\
\text { the Brazilian special shipping } \\
\text { financing system }\end{array}$ & Case study & - & $\begin{array}{l}\text { - The effectiveness of the Brazilian ship financing system is } \\
\text { not significant in reducing of the capital cost of shipping } \\
\text { companies }\end{array}$ \\
\hline Li (2006) & $\begin{array}{l}\text { A review of the advantages and } \\
\text { disadvantages of ship leasing }\end{array}$ & Case study & - & $\begin{array}{l}\text { - Advantages of ship leasing: tax redemptions, efficient } \\
\text { working capital management, better financing conditions } \\
\text { - Disadvantages of ship leasing: limited vessel control, } \\
\text { potential legal conflicts }\end{array}$ \\
\hline $\begin{array}{l}\text { Grammenos et al. } \\
\text { (2007) }\end{array}$ & $\begin{array}{l}\text { Investigation of factors affecting the } \\
\text { pricing of seasoned shipping high } \\
\text { yield bonds in US }\end{array}$ & $\begin{array}{l}40 \text { seasoned bond } \\
\text { issuances }\end{array}$ & $1988-2002$ & $\begin{array}{l}\text { - The following factors are important in explaining U.S. } \\
\text { shipping bond spreads: Credit rating, years to maturity, } \\
\text { changes in earnings, yields and US equity market indices }\end{array}$ \\
\hline $\begin{array}{l}\text { Adland and Jia } \\
\text { (2008) }\end{array}$ & $\begin{array}{l}\text { Charter market default risk in } \\
\text { relation to freight conditions, charter } \\
\text { duration, and charterer's financial } \\
\text { standing }\end{array}$ & $\begin{array}{l}770 \text { weekly } \\
\text { observations }\end{array}$ & $1990-2004$ & $\begin{array}{l}\text { - There is a risk-premium attributable to default risk which is } \\
\text { positively related to freight rate level and charter duration }\end{array}$ \\
\hline $\begin{array}{l}\text { Grammenos et al. } \\
\text { (2008) }\end{array}$ & $\begin{array}{l}\begin{array}{l}\text { Exploring the factors explaining and } \\
\text { predicting defaults for US listed } \\
\text { shipping bonds }\end{array} \\
\end{array}$ & $\begin{array}{l}50 \text { bond } \\
\text { issuances }\end{array}$ & 2003-2010 & $\begin{array}{l}\text { - The probability of default is positively associated with } \\
\text { leverage and issue amount/total assets, but negatively with } \\
\text { liquidity and shipping market conditions }\end{array}$ \\
\hline Merikas et al. (2009) & $\begin{array}{l}\text { Investigation of short- and long-term } \\
\text { performance of global shipping } \\
\text { IPOs }\end{array}$ & 143 IPOs & $1984-2007$ & $\begin{array}{l}\text { - Using market-adjusted returns IPOs are shown to be } \\
\text { underpriced by } 18 \% \text { in the first day and } 16 \% \text { in the long-run } \\
\text { - Long-run performance is positively related to company age } \\
\text { and the reputation of the exchange, but negatively to the } \\
\text { reputation of the underwriter and a hot IPO market }\end{array}$ \\
\hline Merikas et al. (2010) & $\begin{array}{l}\text { Investigation of short-term } \\
\text { performance of shipping IPOs in US }\end{array}$ & 61 IPOs & $1987-2007$ & $\begin{array}{l}\text { - IPOs are underpriced by } 4.4 \% \text { based on market-adjusted } \\
\text { returns }\end{array}$ \\
\hline $\begin{array}{l}\text { Grammenos and } \\
\text { Papapostolou } \\
(2012 b)\end{array}$ & $\begin{array}{l}\text { Testing hypotheses on underpricing } \\
\text { in US shipping IPOs }\end{array}$ & 51 IPOs & $1987-2008$ & $\begin{array}{l}\text { - IPOs are underpriced by } 2.69 \% \text { based on market-adjusted } \\
\text { returns } \\
\text { - The partial adjustment theory is supported as an underpricing } \\
\text { explanation }\end{array}$ \\
\hline Drobetz et al. (2013) & $\begin{array}{l}\text { Analysis of the capital structure } \\
\text { choices of shipping companies }\end{array}$ & $\begin{array}{c}1,442 \\
\text { company-years }\end{array}$ & $1992-2010$ & $\begin{array}{l}\text { - Capital structure of shipping companies shows higher speed } \\
\text { of rebalancing towards the target leverage ratio } \\
\text { - Financial leverage ratio of shipping companies is positively } \\
\text { associated with asset tangibility, and negatively with } \\
\text { profitability, asset risk and operational leverage }\end{array}$ \\
\hline $\begin{array}{l}\text { Drobetz and } \\
\text { Tegtmeier (2013) }\end{array}$ & $\begin{array}{l}\text { Constructing and assessing } \\
\text { performance indices of German KG } \\
\text { funds }\end{array}$ & 323 funds & 1996-2007 & $\begin{array}{l}\text { - The indices appear to fluctuate more with vessel prices rather } \\
\text { than freight rates and exhibit the idiosyncratic risk-return } \\
\text { characteristics of KG funds }\end{array}$ \\
\hline Gong et al. (2013) & $\begin{array}{l}\text { A questionnaire-based survey of } \\
\text { bank financing practices for } \\
\text { shipping projects in Hong Kong }\end{array}$ & 12 banks & 2008 & $\begin{array}{l}\text { - Banks assign higher weighting to loan quality and security } \\
\text { - Banks have reduced their exposures to shipping after the } \\
\text { global financial crisis }\end{array}$ \\
\hline Drobetz et al. (2014) & $\begin{array}{l}\text { Investigation of CSR disclosure and } \\
\text { corporate performance }\end{array}$ & $\begin{array}{l}118 \text { shipping } \\
\text { companies } \\
23 \text { CSR items }\end{array}$ & $2002-2010$ & $\begin{array}{l}\text { - CSR disclosure and financial performance are positively } \\
\text { related } \\
\text { - Company size, financial leverage, and ownership structure } \\
\text { are associated with CSR disclosure }\end{array}$ \\
\hline $\begin{array}{l}\text { Kavussanos and } \\
\text { Tsouknidis (2014) }\end{array}$ & $\begin{array}{l}\text { Investigation of factors explaining } \\
\text { the bond spreads changes of global } \\
\text { shipping bonds }\end{array}$ & $\begin{array}{c}54 \\
\text { bond issuances }\end{array}$ & 2003-2010 & $\begin{array}{l}\text { - Bond liquidity is the most influential factor in explaining } \\
\text { changes in shipping bond spreads as well as stock market } \\
\text { volatility and cyclicality in bond and shipping markets }\end{array}$ \\
\hline $\begin{array}{l}\text { Gavalas and } \\
\text { Syriopoulos (2014) }\end{array}$ & $\begin{array}{l}\text { Developing a multi-criteria } \\
\text { assessment model for shipping bank } \\
\text { loans applications }\end{array}$ & Case study & - & $\begin{array}{l}\text { - The following criteria (and corresponding weights) are } \\
\text { identified: quality of management }(36.37 \%) \text {, financial ratios } \\
(29.52 \%) \text {, leverage }(18.67 \%) \text { and market characteristics } \\
(15.05 \%)\end{array}$ \\
\hline Merika et al. (2015) & $\begin{array}{l}\text { Investigation of determinants of } \\
\text { capital structure }\end{array}$ & $\begin{array}{l}115 \text { listed shipping } \\
\text { companies }\end{array}$ & 2003-2010 & $\begin{array}{l}\text { - Size, tangibility and corporate performance are the main } \\
\text { determinants }\end{array}$ \\
\hline
\end{tabular}




\begin{tabular}{|c|c|c|c|c|}
\hline & & & & $\begin{array}{l}\text { - Negative relationship of leverage with profitability and } \\
\text { concentrated ownership, during different phases of the } \\
\text { business cycle besides the peak of } 2007\end{array}$ \\
\hline $\begin{array}{l}\text { Drobetz et al. } \\
\text { (2016a) }\end{array}$ & $\begin{array}{l}\text { Investigation of the sensitivity of the } \\
\text { financing and investment decisions } \\
\text { to changes in cash-flows for listed } \\
\text { shipping companies }\end{array}$ & $\begin{array}{c}3038 \\
\text { company-years }\end{array}$ & 1989-2012 & $\begin{array}{l}\text { - Financing decision of shipping companies is more sensitive } \\
\text { to adverse cash-flow effects relative to companies in other } \\
\text { industries } \\
\text { - Financing and investing behaviours vary depending on } \\
\text { financial conditions of shipping companies } \\
\text { - Shipping companies adjust their excess cash holdings to } \\
\text { maintain financial flexibility }\end{array}$ \\
\hline $\begin{array}{l}\text { Kavussanos and } \\
\text { Tsouknidis (2016) }\end{array}$ & $\begin{array}{l}\text { Developing a logit credit scoring } \\
\text { model for the assessment of default } \\
\text { risk in shipping bank loans }\end{array}$ & $\begin{array}{c}484 \\
\text { loan-years }\end{array}$ & 1997-2011 & $\begin{array}{l}\text { - The following variables are important in assessing default } \\
\text { risk in shipping bank loans: current and future shipping } \\
\text { market conditions, shipowner's chartering policy and loan } \\
\text { pricing }\end{array}$ \\
\hline $\begin{array}{l}\text { Mitroussi et al. } \\
\text { (2016) }\end{array}$ & $\begin{array}{l}\text { Application of logit credit scoring } \\
\text { model for shipping bank loans }\end{array}$ & 30 loans & 2005-2009 & $\begin{array}{l}\text { - Both financial and non-financial factors explain the } \\
\text { performance of shipping bank loans } \\
\text { - Borrower's experience and market conditions are important } \\
\text { in assessing default risk for shipping bank loans }\end{array}$ \\
\hline Simic et al. (2016) & $\begin{array}{l}\text { Testing the valuation efficiency of } \\
\text { the secondary market for KG funds }\end{array}$ & 341 funds & 2007-2012 & $\begin{array}{l}\text { - The secondary market for KG funds exhibits a high degree } \\
\text { of valuation efficiency } \\
\text { - KG funds are traded at discount relative to their fundamental } \\
\text { values }\end{array}$ \\
\hline $\begin{array}{l}\text { Lozinskaia et al. } \\
\text { (2017) }\end{array}$ & $\begin{array}{l}\text { Investigation of the determinants of } \\
\text { observed defaults for shipping } \\
\text { companies }\end{array}$ & $\begin{array}{c}826 \\
\text { company-years }\end{array}$ & 2001-2016 & $\begin{array}{l}\text { - The probability of default of shipping companies is } \\
\text { positively associated with overvaluation (Tobin's } Q \text { ), and } \\
\text { negatively with GDP growth and company's size }\end{array}$ \\
\hline Nam and An (2017) & $\begin{array}{l}\text { Investigation of the impact of } \\
\text { default risk on company value for } \\
\text { Korean shipping and logistics } \\
\text { companies }\end{array}$ & $\begin{array}{c}2,755 \\
\text { company-years }\end{array}$ & 2003-2012 & $\begin{array}{l}\text { - Positive relationship between Altman K-Score (i.e lower } \\
\text { default risk) and company value }\end{array}$ \\
\hline Satta (2017) & $\begin{array}{l}\text { Investigation of the determinants of } \\
\text { initial day IPO performance of port } \\
\text { operators }\end{array}$ & 58 IPOs & 2001-2015 & $\begin{array}{l}\text { - Underpricing is negatively associated with the age of issuers, } \\
\text { the number of underwriters, reputation of the leading } \\
\text { underwriter, issuers headquartered in countries with } \\
\text { maritime traditions and the institutional setting. }\end{array}$ \\
\hline Satta et al. (2017) & $\begin{array}{l}\text { Investigation of the long-run } \\
\text { performance of global port } \\
\text { operators' IPOs }\end{array}$ & 93 IPOs & 2000-2015 & $\begin{array}{l}\text { - Port IPOs underperform by } 12.18 \% \\
\text { - Port IPO performance is positively associated with political } \\
\text { stability of the home capital market, but negatively with a } \\
\text { bullish stock market, the state-ownership of the issuer and the } \\
\text { period of port privatisation in the issuer's country }\end{array}$ \\
\hline Adland et al. (2017c) & $\begin{array}{l}\text { Major determinants of capital } \\
\text { structure decisions for globally } \\
\text { listed shipbuilding companies }\end{array}$ & 285 company-years & 1997-2013 & $\begin{array}{l}\text { - The key determinants are size, asset risk and the market-to- } \\
\text { book ratio }\end{array}$ \\
\hline Ahrenda et al. (2018) & $\begin{array}{l}\text { Investigation of factors affecting } \\
\text { cash holdings of shipping companies }\end{array}$ & $\begin{array}{c}1,716 \\
\text { company-year }\end{array}$ & 1983-2014 & $\begin{array}{l}\text { - Shipping companies hold more cash than similar } \\
\text { manufacturing companies } \\
\text { - The higher cash holdings of shipping companies are } \\
\text { attributed to the higher marginal value of cash }\end{array}$ \\
\hline Del Gaudio (2018) & $\begin{array}{l}\text { Investigation of financing structure } \\
\text { of Italian shipping companies }\end{array}$ & 500 companies & 2007-2015 & $\begin{array}{l}\text { - Italian shipping companies exhibit high leverage ratios } \\
\text { - Bank credit is a major funding source }\end{array}$ \\
\hline Lee and Pak (2018) & $\begin{array}{l}\text { A survey of factors affecting } \\
\text { shipping banks' underwriting } \\
\text { decision-making }\end{array}$ & 41 banks & 2015 & $\begin{array}{l}\text { - Corporate recourse is the most important factor in the ship- } \\
\text { lending decision, followed by asset cash-flow and asset } \\
\text { value factors } \\
\text { - Shipping bankers perceive shipping loans as a form of } \\
\text { corporate financing, that is safer than asset-backed or project } \\
\text { financing }\end{array}$ \\
\hline
\end{tabular}


Table 6. Summary of Literature on Shipping Investment and Valuation (sorted by year of publication and names of authors)

\begin{tabular}{|c|c|c|c|c|}
\hline \multirow{2}{*}{ STUDY } & \multirow{2}{*}{ DESCRIPTION } & \multicolumn{2}{|c|}{ SAMPLE } & \multirow{2}{*}{ MAIN RESULTS } \\
\hline & & Observations & Period & \\
\hline Miyashita (1982) & $\begin{array}{l}\text { An investigation of the determinants of } \\
\text { dry bulk shipping investments }\end{array}$ & 53 quarters & $1963-1976$ & $\begin{array}{l}\text { - Determinants of the dry-bulk shipping investments are: } \\
\text { the shipping service sales volume per unit of transport } \\
\text { capacity, growth of the shipping service sales volume, } \\
\text { average vessel size, freight rate-to-newbuilding price } \\
\text { ratio and the ratio of broken-up tonnage to the total fleet }\end{array}$ \\
\hline Evans (1984) & $\begin{array}{l}\text { Practical examples of the use of NPV } \\
\text { and IRR in shipping investments. }\end{array}$ & Case study & - & $\begin{array}{l}\text { - Formulas for NPV and IRR calculation for shipping } \\
\text { investments are derived }\end{array}$ \\
\hline Goss (1987) & $\begin{array}{l}\text { Applications of the use of NPV for } \\
\text { shipbuilding loans }\end{array}$ & Case study & - & $\begin{array}{l}\text { - Formulas for NPV calculation in various shipbuilding } \\
\text { loans are derived }\end{array}$ \\
\hline Berg Andreassen (1990) & $\begin{array}{l}\text { A risk-adjusted decision-making } \\
\text { model for investments in tramp } \\
\text { shipping }\end{array}$ & Case study & - & $\begin{array}{l}\text { - Risk averse investors tend to adjust their fleet capacity } \\
\text { toward a long-term mean regardless of the prevailing } \\
\text { shipping market conditions } \\
\text { - Risk lovers tend to expand their fleet capacity even } \\
\text { during volatile shipping markets }\end{array}$ \\
\hline Tvedt (1997) & $\begin{array}{l}\text { Deriving closed-form solutions for the } \\
\text { valuation of VLCC vessels }\end{array}$ & Case study & - & $\begin{array}{l}\text { - Real options analysis (ROA) for valuing VLCC vessels } \\
\text { taking into account the lay-up and scrapping options }\end{array}$ \\
\hline $\begin{array}{l}\text { Cullinane and Panayides } \\
(2000)\end{array}$ & $\begin{array}{l}\text { A questionnaire-based survey of } \\
\text { investment appraisal practices applied } \\
\text { in shipping investments }\end{array}$ & 65 companies & 2000 & $\begin{array}{l}\text { - IRR is the most popular method, followed by NPV and } \\
\text { Payback Period } \\
\text { - Qualitative factors are as important as quantitative ones } \\
\text { in investment decisions }\end{array}$ \\
\hline Bendall and Stent (2003) & $\begin{array}{l}\text { Constructing a binomial tree for ROA } \\
\text { in liner shipping }\end{array}$ & Case study & - & $\begin{array}{l}\text { - Applying ROA to evaluate investments for fleet } \\
\text { expansion/replacement in liner shipping }\end{array}$ \\
\hline $\begin{array}{l}\text { Adland and Koekebakker } \\
\text { (2004) }\end{array}$ & $\begin{array}{l}\text { Trading rules in the dry bulk second- } \\
\text { hand market }\end{array}$ & $\begin{array}{l}324 \text { monthly } \\
\text { observations }\end{array}$ & $1976-2003$ & $\begin{array}{l}\text { - Applying trading rules do not generate excess profits } \\
\text { over the buy-and-hold benchmark when accounting for } \\
\text { transaction costs and vessel price slippage }\end{array}$ \\
\hline Bendall and Stent (2005) & $\begin{array}{l}\text { Constructing a binomial tree for ROA } \\
\text { in liner shipping }\end{array}$ & Case study & - & $\begin{array}{l}\text { - Comparing the value of managerial flexibility in service } \\
\text { network development in liner shipping }\end{array}$ \\
\hline Adland et al. (2006) & $\begin{array}{l}\text { Examine equilibrium relationship } \\
\text { between dry bulk second-hand values, } \\
\text { newbuilding prices and freight rates }\end{array}$ & $\begin{array}{l}132 \text { monthly } \\
\text { observations }\end{array}$ & $1994-2005$ & $\begin{array}{l}\text { - Second-hand market is cointegrated with the freight and } \\
\text { newbuilding markets, with no evidence of a short-term } \\
\text { 'asset bubble' effect }\end{array}$ \\
\hline $\begin{array}{l}\text { Goulielmos and Psifia } \\
(2006 \mathrm{a})\end{array}$ & $\begin{array}{l}\text { Investigation of the statistical } \\
\text { properties of trip-charter rates }\end{array}$ & $\begin{array}{l}379 \text { monthly } \\
\text { observations }\end{array}$ & $1971-2002$ & - Freight rates exhibit long-term persistence (memory) \\
\hline $\begin{array}{l}\text { Goulielmos and Psifia } \\
(2006 \mathrm{~b})\end{array}$ & $\begin{array}{l}\text { Investigation of the statistical } \\
\text { properties of time-charter rates }\end{array}$ & $\begin{array}{l}379 \text { monthly } \\
\text { observations }\end{array}$ & $1971-2002$ & - Freight rates exhibit long-term persistence (memory) \\
\hline $\begin{array}{l}\text { Adland and Koekebakker } \\
\text { (2007) }\end{array}$ & $\begin{array}{l}\text { Multivariate Density Estimation } \\
\text { (MDE) on Sale \& Purchase dry bulk } \\
\text { second-hand vessel values }\end{array}$ & 1850 observations & $1993-2003$ & $\begin{array}{l}\text { - The second-hand vessel value is a partial non-linear } \\
\text { function of deadweight, vessel age, and freight market } \\
\text { conditions }\end{array}$ \\
\hline $\begin{array}{l}\text { Alizadeh and Nomikos } \\
\text { (2007) }\end{array}$ & $\begin{array}{l}\text { Investigation of the profitability of } \\
\text { trading strategies based on relative } \\
\text { valuation }\end{array}$ & $\begin{array}{l}348 \text { monthly } \\
\text { observations }\end{array}$ & $1979-2004$ & $\begin{array}{l}\text { - The deviation of the Price-Earnings ratio from its long- } \\
\text { run average can be used as an investment timing } \\
\text { indicator in the second-hand market }\end{array}$ \\
\hline Bendall and Stent (2007) & $\begin{array}{l}\text { Constructing a binomial tree for ROA } \\
\text { on fleet replacement strategies in liner } \\
\text { shipping }\end{array}$ & Case study & - & $\begin{array}{l}\text { - Assessing the performance of ROA in valuing strategic } \\
\text { flexibility in liner shipping }\end{array}$ \\
\hline Merikas et al. (2008) & $\begin{array}{l}\text { The use of second-hand newbuilding } \\
\text { (SH/NB) price ratio for investment } \\
\text { decision }\end{array}$ & $\begin{array}{l}144 \text { monthly } \\
\text { observations }\end{array}$ & $1995-2006$ & $\begin{array}{l}\text { - } \mathrm{SH} / \mathrm{NB} \text { ratio is cointegrated with freight rates and can } \\
\text { be used as a signal in selecting between newbuilding } \\
\text { and second-hand vessels }\end{array}$ \\
\hline Sødal et al. (2008) & $\begin{array}{l}\text { Deriving closed-form solutions for } \\
\text { valuing real options in shipping. }\end{array}$ & Case study & - & $\begin{array}{l}\text { - ROA as a tool for valuing flexibility (switching options) } \\
\text { in a combination carrier vessel }\end{array}$ \\
\hline Sødal et al. (2009) & $\begin{array}{l}\text { Test decision rules based on a ROA } \\
\text { valuation model of freight rates in the } \\
\text { second-hand vessel market }\end{array}$ & $\begin{array}{l}802 \text { weekly } \\
\text { observations }\end{array}$ & 2001-2005 & $\begin{array}{l}\text { - Overall, the dry bulk second-hand market was efficient, } \\
\text { as switching from a dry bulk to a tanker vessel did not } \\
\text { pay off }\end{array}$ \\
\hline $\begin{array}{l}\text { Jørgensen and De } \\
\text { Giovanni (2010) }\end{array}$ & $\begin{array}{l}\text { Deriving closed-form solutions for } \\
\text { ROA in time-charter with purchasing } \\
\text { options }\end{array}$ & Case study & - & $\begin{array}{l}\text { - Proposing ROA in various strategies in a time-charter } \\
\text { contract with purchasing options }\end{array}$ \\
\hline $\begin{array}{l}\text { Dikos and Thomakos } \\
(2012)\end{array}$ & $\begin{array}{l}\text { Testing the use of ROA in tanker } \\
\text { investment decisions }\end{array}$ & $\begin{array}{l}455 \text { quarterly } \\
\text { observations }\end{array}$ & $1980-2002$ & $\begin{array}{l}\text { - Tanker owners systematically account for the value of } \\
\text { the option to wait in investment decisions }\end{array}$ \\
\hline Rousos and Lee (2012) & $\begin{array}{l}\text { Propose Analytic Hierarchy Process } \\
\text { (AHP) in which shipping investment } \\
\text { appraisal is treated as a multicriteria } \\
\text { optimisation problem }\end{array}$ & Case study & - & $\begin{array}{l}\text { - Analysis shows that non-monetary criteria (such as the } \\
\text { psychology of the decision maker) play an important } \\
\text { role in shipping investment decisions }\end{array}$ \\
\hline Xu and Yip (2012) & $\begin{array}{l}\text { Exploring the factors which affect } \\
\text { newbuilding investment decisions }\end{array}$ & 185 country-years & 1996-2008 & $\begin{array}{l}\text { - Spot freight rates, existing fleet size and world trade } \\
\text { volume are the main determinants of newbuilding } \\
\text { investment decisions } \\
\text { - The cluster effect of major shipbuilding countries is } \\
\text { significant }\end{array}$ \\
\hline Axarloglou et al. (2013) & $\begin{array}{l}\text { Investigation of the determinants of the } \\
\text { time-varying spread between short- } \\
\text { and long-term charter rates using ROA }\end{array}$ & $\begin{array}{l}237 \text { monthly } \\
\text { observations }\end{array}$ & $1992-2011$ & $\begin{array}{l}\text { - Time-varying risk premium is directly related to the } \\
\text { shipping business cycle, the market demand } \\
\text { expectations, and the market's volatility } \\
\text { - Shipowners' decision on commitment of vessels } \\
\text { depends on the value of flexibility against the value of } \\
\text { commitment }\end{array}$ \\
\hline
\end{tabular}




\begin{tabular}{|c|c|c|c|c|}
\hline Bulut et al. (2013) & $\begin{array}{l}\text { Entry decisions and asset allocation in } \\
\text { terms of business cycles in dry bulk }\end{array}$ & $\begin{array}{l}62 \text { yearly } \\
\text { observations }\end{array}$ & $1980-2010$ & $\begin{array}{l}\text { - Ship investors consummate investments around asset } \\
\text { price peaks, which leads to a decline in ROE in the long- } \\
\text { run }\end{array}$ \\
\hline Acciaro (2014) & $\begin{array}{l}\text { Investigates the optimal time for } \\
\text { investment in LNG retrofit based on } \\
\text { ROA framework }\end{array}$ & Case study & - & $\begin{array}{l}\text { - There is a trade-off between low fuel prices and capital } \\
\text { expenses for investment in LNG retrofit }\end{array}$ \\
\hline Kalouptsidi (2014) & $\begin{array}{l}\text { Investigation of the impact of time-to- } \\
\text { build of newbuildings on shipowners' } \\
\text { response to demand shocks in dry bulk } \\
\text { market }\end{array}$ & $\begin{array}{l}1,838 \text { weekly } \\
\text { observations }\end{array}$ & $1998-2010$ & $\begin{array}{l}\text { - Shipping investment activity is more volatile as the } \\
\text { time-to-build period declines, implying that shipowners } \\
\text { respond to economic conditions more rapidly as the } \\
\text { construction lag for a newbuilding vessel reduces }\end{array}$ \\
\hline Papapostolou et al. (2014) & $\begin{array}{l}\text { Investigation of the predictive power } \\
\text { of market sentiment in shipping } \\
\text { investment strategies }\end{array}$ & $\begin{array}{l}192 \text { monthly } \\
\text { observations }\end{array}$ & 1996-2012 & $\begin{array}{l}\text { - Sentiment proxies contain information about future } \\
\text { shipping market conditions } \\
\text { - Trading strategy based on sentiment information is } \\
\text { more profitable than a buy-and-hold strategy }\end{array}$ \\
\hline Adland and Jia (2015) & $\begin{array}{l}\text { Volatility relation between } \\
\text { newbuilding prices and second-hand } \\
\text { prices }\end{array}$ & $\begin{array}{l}\text { TC rates, resale, } \\
\text { scrap age, OPEX }\end{array}$ & 1993-2014 & $\begin{array}{l}\text { - Lower volatility observed in the newbuilding market } \\
\text { relative to the second-hand market which can be } \\
\text { justified by the presence of a term structure of } \\
\text { newbuilding prices }\end{array}$ \\
\hline $\begin{array}{l}\text { Greenwood and Hanson } \\
\text { (2015) }\end{array}$ & $\begin{array}{l}\text { Study of the impact of shipowners' } \\
\text { behaviour on second-hand prices in the } \\
\text { dry bulk market }\end{array}$ & $\begin{array}{l}420 \text { monthly } \\
\text { observations }\end{array}$ & $1976-2011$ & $\begin{array}{l}\text { - A large part of excess volatility in vessel prices can be } \\
\text { attributed to shipowners' behavioural biases; that is, } \\
\text { they overpay for vessels and overinvest during booms, } \\
\text { thus realizing poor subsequent returns }\end{array}$ \\
\hline Rau and Spinler (2016) & $\begin{array}{l}\text { Application of ROA in liner shipping } \\
\text { under oligopolistic market structure }\end{array}$ & Case study & - & $\begin{array}{l}\text { - The number of market participants and the intensity of } \\
\text { competition affect optimal capacity, company values } \\
\text { and investments }\end{array}$ \\
\hline Adland et al. (2017b) & $\begin{array}{l}\text { Estimation of entry-exit optimal } \\
\text { triggers for an Aframax tanker to } \\
\text { switch between refined oil products } \\
\text { and "dirty" oil products }\end{array}$ & $\begin{array}{l}987 \text { weekly } \\
\text { observations }\end{array}$ & $1997-2015$ & $\begin{array}{l}\text { - The value of switching has increased over time, and is } \\
\text { higher than the additional construction cost of a } \\
\text { product tanker }\end{array}$ \\
\hline Alizadeh et al. (2017) & $\begin{array}{l}\text { Investigation of the impact of } \\
\text { heterogeneous beliefs on the volatility } \\
\text { of second-hand ship prices }\end{array}$ & $\begin{array}{l}312 \text { monthly } \\
\text { observations }\end{array}$ & 1991-2016 & $\begin{array}{l}\text { - Momentum strategies perform better than contrarian } \\
\text { (buy-and-hold) strategies } \\
\text { - Higher degree of participation of momentum } \\
\text { (contrarian) investors can lead to increase (decrease) in } \\
\text { the volatility of second-hand ship prices }\end{array}$ \\
\hline Balliauw (2017) & $\begin{array}{l}\text { Utilises real options model to analyse } \\
\text { the buy (entry) and sell (exit) decisions } \\
\text { of container shipowners }\end{array}$ & Case study & - & $\begin{array}{l}\text { - Market entry and exit thresholds have been estimated } \\
\text { and the estimated values appear to be } \\
\text { plausible/attainable }\end{array}$ \\
\hline Clintworth et al. (2017) & \begin{tabular}{|l|} 
Employ an AHP-based MCDM \\
approach for fleet expansion project \\
taking into account financial and non- \\
financial criteria whilst accounting for \\
the inherent subjectivity in \\
investment decision making
\end{tabular} & Case study & - & $\begin{array}{l}\text { - The model is applied to a fleet expansion project } \\
\text { which has been financed by the EIB }\end{array}$ \\
\hline Kyriakou et al. (2017b) & $\begin{array}{l}\text { Develop a ROA framework for } \\
\text { evaluating investments in dry bulk } \\
\text { vessels }\end{array}$ & Case study & - & $\begin{array}{l}\text { - Proposed model captures flexibly the drybulk market } \\
\text { behavior } \\
\text { - Long-run freight rate and volatility have an impact on } \\
\text { the investment timing and value } \\
\text { - A high opportunity cost is embedded in the investment } \\
\text { decision due to construction lags }\end{array}$ \\
\hline Papapostolou et al. (2017) & $\begin{array}{l}\text { Investigation of the impact of herding } \\
\text { behaviour in the dry bulk segment }\end{array}$ & $\begin{array}{l}233 \text { monthly } \\
\text { observations }\end{array}$ & $1996-2015$ & $\begin{array}{l}\text { - Unintentional herding affects decisions on newbuilding } \\
\text { ordering and scrapping } \\
\text { - The impact of unintentional herding is more significant } \\
\text { in the scrapping market during unfavourable shipping } \\
\text { market conditions }\end{array}$ \\
\hline Chou and Chen (2018) & $\begin{array}{l}\text { Investigation of profitability of trading } \\
\text { rules for second hand dry bulk vessels }\end{array}$ & $\begin{array}{l}337 \text { monthly } \\
\text { observations }\end{array}$ & $1986-2014$ & $\begin{array}{l}\text { - Trading rules based on technical analysis generally } \\
\text { outperform a benchmark buy-and-hold strategy } \\
\text { - S\&P strategies based on Bollinger bands can result in } \\
\text { excess profits for Capesize and Handysize vessels }\end{array}$ \\
\hline
\end{tabular}


Table 7. Summary of Literature on Cost of Capital and Sources of Risk in Shipping Investments (sorted by year of publication and names of authors)

\begin{tabular}{|c|c|c|c|c|}
\hline \multirow{2}{*}{ STUDY } & \multirow{2}{*}{ DESCRIPTION } & \multicolumn{2}{|c|}{ SAMPLE } & \multirow{2}{*}{ MAIN RESULTS } \\
\hline & & Observations & Period & \\
\hline Cullinane (1995) & $\begin{array}{l}\text { An investigation of optimal shipping } \\
\text { investment strategies in the context } \\
\text { of portfolio theory }\end{array}$ & Case study & - & $\begin{array}{l}\text { - Shipping investment strategy can be constructed based on } \\
\text { the portfolio optimisation problem } \\
\text { - Shipowners can construct optimal shipping portfolios } \\
\text { using a mix of different chartering contracts and freight } \\
\text { rate futures }\end{array}$ \\
\hline $\begin{array}{l}\text { Kavussanos and } \\
\text { Marcoulis (1997a) }\end{array}$ & $\begin{array}{l}\text { An investigation of the betas of } \\
\text { shipping stocks in the U.S. }\end{array}$ & $\begin{array}{c}3,360 \\
\text { company-months }\end{array}$ & 1985-1995 & $\begin{array}{l}\text { - Betas of shipping stocks are lower than market's beta } \\
\text { (one), but not always statistically significant } \\
\text { - Volatility in shipping stock prices can be largely explained } \\
\text { by non-systematic risk factors }\end{array}$ \\
\hline $\begin{array}{l}\text { Kavussanos and } \\
\text { Marcoulis (1997b) }\end{array}$ & $\begin{array}{l}\text { An exploration of the betas of } \\
\text { transportation stocks in the U.S. and } \\
\text { micro-economic risk factors }\end{array}$ & $\begin{array}{c}21,912 \\
\text { company-months }\end{array}$ & 1984-1995 & $\begin{array}{l}\text { - Betas of shipping stocks are lower than one and } \\
\text { statistically significant } \\
\text { - Returns of shipping stocks are negatively related to Asset- } \\
\text { to-Equity (book value) ratio }\end{array}$ \\
\hline $\begin{array}{l}\text { Kavussanos and } \\
\text { Marcoulis (1998) }\end{array}$ & $\begin{array}{l}\text { An empirical study of the betas of } \\
\text { shipping stocks is the U.S. and their } \\
\text { comparison with stocks in other } \\
\text { industries }\end{array}$ & $\begin{array}{c}21,912 \\
\text { company-months }\end{array}$ & 1984-1995 & $\begin{array}{l}\text { - Betas of shipping stocks are lower than market's average } \\
\text { beta } \\
\text { - Betas of air, rail and truck sectors are not different from } \\
\text { the market average } \\
\text { - Betas of real estate stocks are significantly lower than } \\
\text { those of shipping stocks }\end{array}$ \\
\hline $\begin{array}{l}\text { Kavussanos and } \\
\text { Marcoulis (2000a) }\end{array}$ & $\begin{array}{l}\text { A study devoted on the impact of } \\
\text { macro-economic factors on shipping } \\
\text { stock returns in the U.S. }\end{array}$ & $\begin{array}{c}19,920 \\
\text { company-months }\end{array}$ & 1985-1995 & $\begin{array}{l}\text { - Betas of shipping stocks are lower than one and } \\
\text { statistically significant } \\
\text { - Returns of shipping stocks exhibit a positive association } \\
\text { with changes in oil prices and a negative one with changes } \\
\text { in industrial production }\end{array}$ \\
\hline $\begin{array}{l}\text { Kavussanos and } \\
\text { Marcoulis (2000b) }\end{array}$ & $\begin{array}{l}\text { An investigation of impact of both } \\
\text { macro- and micro-economic factors } \\
\text { on shipping stock returns in the U.S. }\end{array}$ & $\begin{array}{c}19,800 \\
\text { company-months }\end{array}$ & 1985-1995 & $\begin{array}{l}\text { - Returns of shipping stocks are positively associated with } \\
\text { changes in oil prices, but negatively associated with Asset- } \\
\text { to-Equity (book value) ratio and changes in industrial } \\
\text { production }\end{array}$ \\
\hline $\begin{array}{l}\text { Kavussanos et al. } \\
(2003)\end{array}$ & $\begin{array}{l}\text { An empirical study of the betas of } \\
\text { publicly-listed shipping companies } \\
\text { by segments }\end{array}$ & $\begin{array}{c}3,996 \\
\text { company-months }\end{array}$ & 1996-1999 & $\begin{array}{l}\text { - On average, betas of shipping stocks are significantly } \\
\text { lower than the average beta in the market } \\
\text { - Betas of the drilling sector are significantly higher than the } \\
\text { market average, while those of other sectors are either } \\
\text { lower (or not different) when compared to the market } \\
\text { average }\end{array}$ \\
\hline Grelck et al. (2009) & $\begin{array}{l}\text { Testing portfolio efficiency when } \\
\text { including shipping stocks }\end{array}$ & 41 stocks & 1999-2007 & $\begin{array}{l}\text { - Inclusion of shipping stocks improves the overall portfolio } \\
\text { efficiency } \\
\text { - Benefits from diversification are more significant during } \\
\text { bearish markets }\end{array}$ \\
\hline Drobetz et al. (2010) & $\begin{array}{l}\text { An investigation of the impact of } \\
\text { macro-economic factors on global } \\
\text { shipping stock returns }\end{array}$ & $\begin{array}{c}1,728 \\
\text { company-months }\end{array}$ & 1999-2007 & $\begin{array}{l}\text { - Betas of shipping stocks are lower than one and } \\
\text { statistically significant } \\
\text { - Returns of shipping stocks are positively related to the } \\
\text { changes in oil prices, but negatively related to the changes } \\
\text { in industrial production and the value of the US dollar } \\
\text { relative to other major currencies }\end{array}$ \\
\hline Tezuka et al. (2012) & $\begin{array}{l}\text { An exploration of the time-varying } \\
\text { beta of stocks of Japanese liner } \\
\text { shipping companies }\end{array}$ & $\begin{array}{c}3,240 \\
\text { company-months }\end{array}$ & $1980-2006$ & $\begin{array}{l}\text { - Betas of stocks of Japanese liner shipping companies are } \\
\text { time-varying. The fluctuations observed are associated } \\
\text { with policies and regulation regarding market competition } \\
\text { in Japan }\end{array}$ \\
\hline $\begin{array}{l}\text { Andriosopoulos et al. } \\
\text { (2013) }\end{array}$ & $\begin{array}{l}\text { A replication of shipping indexes } \\
\text { and construction of portfolios of } \\
\text { U.S. stocks }\end{array}$ & $\begin{array}{c}1,514 \\
\text { daily prices }\end{array}$ & 2006-2012 & $\begin{array}{l}\text { - The portfolio consisting of Dow Jones stocks (based on a } \\
\text { Genetic Algorithm procedure) produces minimum errors } \\
\text { when tracking a shipping stock composite index }\end{array}$ \\
\hline $\begin{array}{l}\text { Panayides et al. } \\
\text { (2013) }\end{array}$ & $\begin{array}{l}\text { An empirical study of the impact of } \\
\text { liquidity risk premium on shipping } \\
\text { stock returns in the U.S. }\end{array}$ & 76 companies & $1960-2009$ & $\begin{array}{l}\text { - Illiquidity risk is priced in shipping stocks beyond market- } \\
\text { wide illiquidity and other risk factors }\end{array}$ \\
\hline $\begin{array}{l}\text { Drobetz et al. } \\
\text { (2016b) }\end{array}$ & $\begin{array}{l}\text { An investigation of the impact of } \\
\text { macro- and micro-economic and } \\
\text { industry-specific factors on betas of } \\
\text { global shipping stocks }\end{array}$ & $\begin{array}{c}1,363 \\
\text { company-years }\end{array}$ & $1990-2013$ & $\begin{array}{l}\text { - Betas of shipping stocks fluctuate with shipping market } \\
\text { cycles } \\
\text { - Betas of shipping stocks are positively affected by } \\
\text { operating leverage and financial leverage, growth } \\
\text { opportunities, default risk, freight rate volatility and credit } \\
\text { spread, but negatively affected by corporate liquidity and } \\
\text { changes in industrial production }\end{array}$ \\
\hline Kuo, et al. (2016) & $\begin{array}{l}\text { Freight risk-return relationship in } \\
\text { the dry-bulk sub-sector after the } \\
2008 \text { financial crises }\end{array}$ & $\begin{array}{c}3,127 \text { daily } \\
\text { observations }\end{array}$ & $2000-2013$ & $\begin{array}{l}\text { - Risk-return (measure by beta) has changed for Capesize } \\
\text { vessels from high-risk/high-return into high-risk/low- } \\
\text { return }\end{array}$ \\
\hline $\begin{array}{l}\text { Pouliasis et al. } \\
\text { (2017) }\end{array}$ & $\begin{array}{l}\text { Examine the dynamics of stock } \\
\text { price volatility for tail behavior and } \\
\text { tail risk dependence in the dry bulk, } \\
\text { tanker, container and gas sectors }\end{array}$ & $\begin{array}{l}3,261 \text { daily closing } \\
\text { stock prices }\end{array}$ & 2003-2016 & $\begin{array}{l}\text { - Large losses are strongly correlated, associated with an } \\
\text { asymmetric transmission processes } \\
\text { - Importance of risk monitoring, as extreme losses in a } \\
\text { sector can be transmitted to other sectors }\end{array}$ \\
\hline
\end{tabular}


Table 8. Summary of Literature on M\&As in Shipping and Value Creation (sorted by year of publication and names of authors)

\begin{tabular}{|c|c|c|c|c|}
\hline \multirow{2}{*}{ STUDY } & \multirow{2}{*}{ DESCRIPTION } & \multicolumn{2}{|c|}{ SAMPLE } & \multirow{2}{*}{ MAIN RESULTS } \\
\hline & & Observations & Period & \\
\hline $\begin{array}{l}\text { Panayides and Gong } \\
(2002)\end{array}$ & $\begin{array}{l}\text { Investigation of short-term value } \\
\text { creation in liner shipping M\&As }\end{array}$ & 2 deals & 1995-1999 & $\begin{array}{l}\text { - Acquirer CAR: } 83 \% \text {; Target CAR: } 148 \% \\
\text { - Larger share of synergy gains accrues to targets }\end{array}$ \\
\hline $\begin{array}{l}\text { Samitas and Kenourgios } \\
\text { (2007) }\end{array}$ & $\begin{array}{l}\text { Investigation of short-term value } \\
\text { creation in tramp shipping M\&As }\end{array}$ & 15 deals & 2004-2007 & $\begin{array}{l}\text { - Five-day CAR for acquirers is between }-0.3 \% \text { and } 0.8 \% \\
\text { - CAR to acquirers is generally negative in pre- } \\
\text { announcement periods, but positive in post- } \\
\text { announcements period }\end{array}$ \\
\hline $\begin{array}{l}\text { Syriopoulos and } \\
\text { Theotokas (2007) }\end{array}$ & $\begin{array}{l}\text { Examine short-term value creation in } \\
\text { tramp shipping M\&As }\end{array}$ & 3 bids & 2004 & $\begin{array}{l}\text { - CAR for targets between } 5.06 \% \text { and } 22.13 \% \text {, and CAR } \\
\text { for acquirers between }-22.4 \% \text { and } 1.58 \%\end{array}$ \\
\hline Darkow et al. (2008) & $\begin{array}{l}\text { Examine short-term value creation in } \\
\text { M\&As in the logistics industry }\end{array}$ & 200 deals & 1991-2006 & $\begin{array}{l}\text { - Acquirer CAR: } 1.6 \% \text {; Target CAR: } 10.60 \% \\
\text { - Larger synergy gains for horizontal, cross-border and } \\
\text { large deals }\end{array}$ \\
\hline Fusillo (2009) & $\begin{array}{l}\text { Investigate M\&A drivers in U.S. liner } \\
\text { shipping }\end{array}$ & 54 deals & 1993-2006 & $\begin{array}{l}\text { - M\&A activity positively related to excess capacity, } \\
\text { demand growth, changes in regulation, and negatively } \\
\text { related to freight rates }\end{array}$ \\
\hline Merikas et al. (2011) & $\begin{array}{l}\text { Investigate the disciplinary motives for } \\
\text { takeovers in shipping by comparing } \\
\text { financial profiles of constituent } \\
\text { companies }\end{array}$ & 60 companies & 1994-2009 & $\begin{array}{l}\text { - Provide support to poor management hypothesis } \\
\text { - Acquirers outperform targets based on } 5 \text { criteria } \\
\text { including ROA, gross margin, enterprise value and } \\
\text { debt-to-capital }\end{array}$ \\
\hline Andreou et al. (2012) & $\begin{array}{l}\text { Investigation of short-term value } \\
\text { creation in U.S. transportation M\&As }\end{array}$ & 285 deals & 1980-2009 & $\begin{array}{l}\text { - Acquirer CAR: } 2.3 \% \text {; Target CAR: } 24.5 \% \\
\text { - Vertical deals outperform horizontal consolidation }\end{array}$ \\
\hline Choi and Yoshida (2013) & $\begin{array}{l}\text { Investigation of long-term operating } \\
\text { performance of firms involved in } \\
\text { Japanese shipping M\&As }\end{array}$ & 2 deals & 1998-1999 & $\begin{array}{l}\text { - Enhanced market share for the combined entities driven } \\
\text { by the aggregation of their fleets, and improvements in } \\
\text { asset turnover, profitability, and gearing ratio during the } \\
\text { 5-year post-merger period }\end{array}$ \\
\hline Yeo (2013) & $\begin{array}{l}\text { Investigation of the impact of } \\
\text { geographical distance on shipping } \\
\text { M\&A activity }\end{array}$ & 120 deals & 2006-2007 & $\begin{array}{l}\text { - Geographical distance between acquirer and target has } \\
\text { a negative effect on M\&A intensity in the shipping } \\
\text { industry } \\
\text { - The negative impact of distance is mitigated as the size } \\
\text { of acquirer increases }\end{array}$ \\
\hline Alexandrou et al. (2014) & $\begin{array}{l}\text { Investigation of short-term value } \\
\text { creation in global shipping M\&As }\end{array}$ & 1,266 deals & 1984-2011 & $\begin{array}{l}\text { - Acquirer CAR: } 1.2 \% \text {; Target CAR: } 3.3 \% \\
\text { - Acquirer gain is higher in acquisitions of publicly listed } \\
\text { targets }\end{array}$ \\
\hline
\end{tabular}

Table 9. Summary of Literature on Corporate Governance of Shipping Companies (sorted by year of publication and names of authors)

\begin{tabular}{|c|c|c|c|c|}
\hline \multirow{2}{*}{ STUDY } & \multirow{2}{*}{ DESCRIPTION } & \multicolumn{2}{|c|}{ SAMPLE } & \multirow{2}{*}{ MAIN RESULTS } \\
\hline & & Observations & Period & \\
\hline Randøy et al. (2003) & $\begin{array}{l}\text { Examine the impact of corporate } \\
\text { governance on financial performance of } \\
\text { Scandinavian shipping companies }\end{array}$ & $\begin{array}{c}91 \\
\text { company-years }\end{array}$ & 1996-1998 & $\begin{array}{l}\text { - Positive effect of founding-family CEO and board } \\
\text { independence on financial performance }\end{array}$ \\
\hline Koufopoulos et al. (2010) & $\begin{array}{l}\text { Examine corporate governance structure } \\
\text { of Greek shipping companies }\end{array}$ & 27 companies & 2006 & $\begin{array}{l}\text { - CEO influence is more pronounced with CEO } \\
\text { duality, small sized-board and low board } \\
\text { independence }\end{array}$ \\
\hline $\begin{array}{l}\text { Syriopoulos and } \\
\text { Tsatsaronis (2011) }\end{array}$ & $\begin{array}{l}\text { Investigation of the impact of corporate } \\
\text { governance on financial performance of } \\
\text { Greek shipping companies }\end{array}$ & $\begin{array}{c}55 \\
\text { company-years }\end{array}$ & 2004-2008 & $\begin{array}{l}\text { - Corporate performance is positively related to } \\
\text { incidence of founding-family CEO, and negatively to } \\
\text { board independence } \\
\text { - Curvilinear relationship between board ownership } \\
\text { and corporate performance }\end{array}$ \\
\hline $\begin{array}{l}\text { Syriopoulos and } \\
\text { Tsatsaronis (2012) }\end{array}$ & $\begin{array}{l}\text { Investigation of the impact of CEO } \\
\text { duality on corporate performance of } \\
\text { Greek U.S. listed shipping companies }\end{array}$ & $\begin{array}{c}301 \\
\text { company-years }\end{array}$ & 2002-2008 & $\begin{array}{l}\text { - CEO duality has a negative impact on financial } \\
\text { performance }\end{array}$ \\
\hline Tsionas et al. (2012) & $\begin{array}{l}\text { Examine the impact of corporate } \\
\text { governance on financial performance of } \\
\text { global shipping companies }\end{array}$ & 126 companies & 2009 & $\begin{array}{l}\text { - Positive effect of ownership concentration on } \\
\text { corporate performance } \\
\text { - Company size, stock market liquidity and financial } \\
\text { performance are major determinants of ownership } \\
\text { concentration }\end{array}$ \\
\hline Andreou et al. (2014) & $\begin{array}{l}\text { Examine the relationship between } \\
\text { corporate governance and financial } \\
\text { management decisions and performance } \\
\text { of U.S. shipping companies }\end{array}$ & $\begin{array}{c}273 \\
\text { company-years }\end{array}$ & $1999-2010$ & $\begin{array}{l}\text { - Concentrated ownership has no effect on financial } \\
\text { Insider ownership, board size, the presence of } \\
\text { corporate governance committees, inter-linked } \\
\text { boards and CEO duality are associated with financial } \\
\text { management decisions and firm performance. }\end{array}$ \\
\hline Pastra et al. (2015) & $\begin{array}{l}\text { Investigation of board characteristics of } \\
\text { Greek-owned public listed shipping } \\
\text { companies }\end{array}$ & 28 companies & 2001-2012 & $\begin{array}{l}\text { - CEO Duality in } 15 \text { cases } \\
\text { - Board size is 6-7 members with tenure } 48.33 \text { months } \\
\text { on average } \\
\text { - Only } 13 \text { women (out of } 305 \text { ) in directorships }\end{array}$ \\
\hline
\end{tabular}

Table 10. Summary of Literature on Freight Rate Volatility and Shipping Segmentation Effects (sorted by year of publication and names of authors) 


\begin{tabular}{|c|c|c|c|c|}
\hline \multirow{2}{*}{ STUDY } & \multirow{2}{*}{ DESCRIPTION } & \multicolumn{2}{|l|}{ SAMPLE } & \multirow{2}{*}{ MAIN RESULTS } \\
\hline & & Observations & Period & \\
\hline Kavussanos (1996) & $\begin{array}{l}\text { Examination of volatility in freight } \\
\text { rates of dry bulk segment }\end{array}$ & $\begin{array}{l}720 \text { monthly } \\
\text { freight rates }\end{array}$ & 1973-1992 & $\begin{array}{l}\text { - Volatility in dry bulk freight rates is time-varying. } \\
\text { - The larger the vessel size and the lengthier the time- } \\
\text { charter contract the higher the volatility in freight rates } \\
\text { and vessel prices, respectively }\end{array}$ \\
\hline Kavussanos (1997) & $\begin{array}{l}\text { Examination of volatility in the dry bulk } \\
\text { second-hand market }\end{array}$ & $\begin{array}{l}708 \text { monthly } \\
\text { prices }\end{array}$ & 1976-1995 & $\begin{array}{l}\text { - Volatility in second-hand vessel prices is positively } \\
\text { related with the size of the vessel }\end{array}$ \\
\hline Kavussanos (2003) & $\begin{array}{l}\text { Examination of volatility in the tanker } \\
\text { segment }\end{array}$ & $\begin{array}{l}732 \text { monthly } \\
\text { freight rates }\end{array}$ & 1979-1994 & $\begin{array}{l}\text { - Volatility in tanker freight rates is time-varying } \\
\text { - Volatility is higher in spot freight contracts and larger } \\
\text { vessels }\end{array}$ \\
\hline Chen et al. (2010) & $\begin{array}{l}\text { Investigation of spillover effects } \\
\text { between Capesize and Panamax freight } \\
\text { markets }\end{array}$ & $\begin{array}{l}19,500 \text { daily } \\
\text { freight rates }\end{array}$ & 1999-2008 & $\begin{array}{l}\text { - Markets are interrelated in terms of returns and } \\
\text { volatilities. Shipping market conditions affect the } \\
\text { degree of the identified spillovers }\end{array}$ \\
\hline Drobetz et al. (2012) & $\begin{array}{l}\text { Investigation of the impact of macro- } \\
\text { economic variables on volatility in dry } \\
\text { bulk and tanker markets }\end{array}$ & $\begin{array}{l}12,000 \text { daily } \\
\text { freight rates }\end{array}$ & 1999-2011 & $\begin{array}{l}\text { - Yield curve explains volatility in both the dry bulk and } \\
\text { tanker freight rate markets } \\
\text { - Asymmetric effects are documented only in the tanker } \\
\text { freight rate market }\end{array}$ \\
\hline $\begin{array}{l}\text { Alizadeh and Talley } \\
\text { (2011a) }\end{array}$ & $\begin{array}{l}\text { Investigation of the microeconomic } \\
\text { factors that determine dry bulk freight } \\
\text { rates }\end{array}$ & $\begin{array}{l}\text { Fixtures for } \\
\text { 3,039 Capesize } \\
\text { 9,076 Panamax }\end{array}$ & 2003-2009 & $\begin{array}{l}\text { - Freight rates are positively related to the length of the } \\
\text { laycan period and the vessel size (dwt) } \\
\text { - A simultaneous relationship exists between freight rates } \\
\text { and lengths of the laycan periods }\end{array}$ \\
\hline $\begin{array}{l}\text { Alizadeh and Talley } \\
(2011 \mathrm{~b})\end{array}$ & $\begin{array}{l}\text { Investigation of the microeconomic } \\
\text { factors that determine tanker freight } \\
\text { rates }\end{array}$ & \begin{tabular}{|c|} 
Fixtures for \\
3,435 VLCC \\
3,994 Suezmax \\
6,682 Aframax \\
\end{tabular} & 2006-2009 & $\begin{array}{l}\text { - The duration of the laycan period, the vessel's hull type, } \\
\text { fixture deadweight utilization ratio, vessel age and } \\
\text { voyage routes are found as important determinants }\end{array}$ \\
\hline Dai et al. (2015) & $\begin{array}{l}\text { Investigate vessel price volatility and } \\
\text { neglected determinants. }\end{array}$ & $\begin{array}{l}203 \text { monthly } \\
\text { prices }\end{array}$ & $1996-2012$ & $\begin{array}{l}\text { - Freight rate volatility, is the most important } \\
\text { determinant, together with shipyard capacity change, } \\
\text { exchange rate volatility, and shipbuilding cost volatility }\end{array}$ \\
\hline Tsouknidis (2016) & $\begin{array}{l}\text { Investigation of time-varying spillover } \\
\text { effects between and within the dry bulk } \\
\text { and tanker freight rate markets }\end{array}$ & $\begin{array}{l}21,578 \text { daily } \\
\text { freight rates }\end{array}$ & $1998-2015$ & $\begin{array}{l}\text { - Volatility spillovers are overall large and time-varying } \\
\text { between shipping freight rates markets } \\
\text { - The volatility spillovers revealed are more pronounced } \\
\text { during and after the global financial crisis period } \\
\text { - The direction of spillovers is from small-sized vessels } \\
\text { to large-sized vessels and from tanker to dry bulk freight } \\
\text { rate markets }\end{array}$ \\
\hline
\end{tabular}

Table 11. Summary of Literature on Risk Measurement and Management in Shipping (sorted by year of publication and names of authors)

\begin{tabular}{|c|c|c|c|c|}
\hline \multirow{2}{*}{ STUDY } & \multirow{2}{*}{ DESCRIPTION } & \multicolumn{2}{|c|}{ SAMPLE } & \multirow{2}{*}{ MAIN RESULTS } \\
\hline & & Observations & Period & \\
\hline $\begin{array}{l}\text { Thoung and Visscher } \\
\text { (1990) }\end{array}$ & $\begin{array}{l}\text { Investigation of the hedging } \\
\text { effectiveness of BIFFEX contracts }\end{array}$ & 154 weekly prices & 1986-1988 & $\begin{array}{l}\text { - BIFFEX contracts can be an effective hedging tool for } \\
\text { shippers of grain and coal, with long-haul cargo, and } \\
\text { in need of dry bulk vessels }\end{array}$ \\
\hline Cullinane (1991) & $\begin{array}{l}\text { Questionnaire survey for BIFFEX } \\
\text { contracts among shipping companies }\end{array}$ & 85 companies & - & $\begin{array}{l}\text { - Shipping companies are aware of the existence of } \\
\text { BIFFEX } \\
\text { - However, BIFFEX is not accepted as a viable hedging } \\
\text { tool by most shipping companies }\end{array}$ \\
\hline Cullinane (1992) & $\begin{array}{l}\text { Investigation of the forecasting } \\
\text { performance of BFI }\end{array}$ & 1,000 daily prices & 1985-1988 & - ARIMA models can predict short-term BFI \\
\hline Chang and Chang (1996) & $\begin{array}{l}\text { Examination of the predictability of } \\
\text { dry-bulk spot rates using BIFFEX }\end{array}$ & $\begin{array}{l}15,820 \text { daily } \\
\text { prices }\end{array}$ & 1985-1993 & $\begin{array}{l}\text { - BIFFEX can predict the spot freight rates up to six } \\
\text { months }\end{array}$ \\
\hline Tvedt (1998) & $\begin{array}{l}\text { Closed-form pricing for options on } \\
\text { BIFFEX futures }\end{array}$ & Case Study & - & $\begin{array}{l}\text { - The pricing model takes into account special features } \\
\text { of shipping derivatives market, such as downward } \\
\text { restriction of the prices of underlying assets }\end{array}$ \\
\hline Cullinane (1999) & $\begin{array}{l}\text { Examination of the impact of changes } \\
\text { in the BFI composition }\end{array}$ & 600 daily prices & 1993-1996 & $\begin{array}{l}\text { - The exclusion of Handysize routes has a weak impact } \\
\text { on improving BFI behaviour as a general freight rates } \\
\text { index }\end{array}$ \\
\hline $\begin{array}{l}\text { Kavussanos and Nomikos } \\
(1999)\end{array}$ & $\begin{array}{l}\text { Investigation of the unbiasedness } \\
\text { hypothesis of freight futures prices }\end{array}$ & $\begin{array}{l}106 \text { monthly } \\
\text { prices }\end{array}$ & 1988-1997 & $\begin{array}{l}\text { - Short-term freight futures can be regarded as unbiased } \\
\text { forecasts of the realised spot freight prices }\end{array}$ \\
\hline $\begin{array}{l}\text { Mayr and Tamvakis } \\
\text { (1999) }\end{array}$ & $\begin{array}{l}\text { Investigation of the casual relationship } \\
\text { between oil product futures and } \\
\text { physical crude oil }\end{array}$ & $\begin{array}{l}148 \text { monthly } \\
\text { prices }\end{array}$ & 1985-1997 & $\begin{array}{l}\text { - A causal relationship runs from the two-month crack } \\
\text { spreads to crude oil imports } \\
\text { - Causality can serve as a leading indicator for short- } \\
\text { term tanker vessel demand }\end{array}$ \\
\hline Haigh (2000) & $\begin{array}{l}\text { Investigation of cointegration between } \\
\text { freight futures and spot freight rates }\end{array}$ & $\begin{array}{l}111 \text { monthly } \\
\text { prices }\end{array}$ & 1985-1999 & $\begin{array}{l}\text { - BIFFEX futures can be regarded as unbiased forecasts } \\
\text { of the spot freight prices } \\
\text { - The futures price for the current month contract } \\
\text { outperforms time-series models in forecasting spot } \\
\text { prices }\end{array}$ \\
\hline $\begin{array}{l}\text { Kavussanos and Nomikos } \\
\text { (2000a) }\end{array}$ & $\begin{array}{l}\text { Investigation of hedging effectiveness } \\
\text { of BIFFEX contracts }\end{array}$ & 267 weekly prices & 1992-1997 & $\begin{array}{l}\text { - Time-varying hedging models outperform other } \\
\text { models in reducing freight rate risks, but with a large } \\
\text { basis risk }\end{array}$ \\
\hline $\begin{array}{l}\text { Kavussanos and Nomikos } \\
\text { (2000b) }\end{array}$ & $\begin{array}{l}\text { Examination of hedging performance } \\
\text { of BIFFEX contracts and the impact of } \\
\text { the change in contract composition }\end{array}$ & 487 weekly prices & 1988-1997 & $\begin{array}{l}\text { - The change in BIFFEX composition enhances } \\
\text { hedging performance of freight futures contracts }\end{array}$ \\
\hline
\end{tabular}




\begin{tabular}{|c|c|c|c|c|}
\hline \multirow{2}{*}{ STUDY } & \multirow{2}{*}{ DESCRIPTION } & \multicolumn{2}{|c|}{ SAMPLE } & \multirow{2}{*}{ MAIN RESULTS } \\
\hline & & Observations & Period & \\
\hline $\begin{array}{l}\text { Kavussanos and Nomikos } \\
(2000 \mathrm{c})\end{array}$ & $\begin{array}{l}\text { Comparison of performance of } \\
\text { constant and time-varying hedging } \\
\text { models }\end{array}$ & 267 weekly prices & 1992-1997 & $\begin{array}{l}\text { - The GARCH-X model outperforms a simple GARCH } \\
\text { and constant hedging specifications }\end{array}$ \\
\hline Haigh and Holt (2002) & $\begin{array}{l}\text { Examination of the relationships } \\
\text { between freight rates, commodity and } \\
\text { foreign exchange futures markets }\end{array}$ & 715 weekly prices & 1985-1998 & $\begin{array}{l}\text { - Traders can achieve better hedging effectiveness when } \\
\text { they incorporate inter-dependence of various futures } \\
\text { contracts } \\
\text { - Freight futures are not a crucial hedging tool for } \\
\text { traders }\end{array}$ \\
\hline $\begin{array}{l}\text { Dinwoodie and Morris } \\
(2003)\end{array}$ & $\begin{array}{l}\text { Questionnaire survey for FFAs among } \\
\text { tanker shipowners and charterers }\end{array}$ & 30 companies & 2001 & $\begin{array}{l}\text { - Although FFAs are widely perceived, the vast } \\
\text { majority of respondents had never used them } \\
\text { - Technical education is essential to widespread } \\
\text { acceptance }\end{array}$ \\
\hline $\begin{array}{l}\text { Kavussanos and Nomikos } \\
\text { (2003) }\end{array}$ & $\begin{array}{l}\text { Investigation of the causal relationship } \\
\text { between freight futures and spot } \\
\text { freight rates }\end{array}$ & 2,462 daily prices & 1988-1998 & $\begin{array}{l}\text { - Futures prices tend to discover new information more } \\
\text { rapidly than spot prices } \\
\text { - Freight futures can be used as unbiased forecasts of } \\
\text { the realised spot freight rates }\end{array}$ \\
\hline Alizadeh et al. (2004) & $\begin{array}{l}\text { Investigation of hedging bunker price } \\
\text { fluctuations using crude oil and } \\
\text { petroleum futures }\end{array}$ & 642 weekly prices & $1988-2000$ & $\begin{array}{l}\text { - Hedging performance varies across the different } \\
\text { bunker markets } \\
\text { - Crude oil futures exhibit the highest hedging } \\
\text { effectiveness for Rotterdam and Singapore spot } \\
\text { bunker prices }\end{array}$ \\
\hline $\begin{array}{l}\text { Alizadeh and Nomikos } \\
\text { (2004) }\end{array}$ & $\begin{array}{l}\text { Examination of the relationships } \\
\text { between oil futures and spot oil } \\
\text { markets and tanker freight rates }\end{array}$ & 451 weekly prices & 1993-2001 & $\begin{array}{l}\text { - There is no significant relationship between tanker } \\
\text { freight rates and physical-futures differentials in the } \\
\text { oil market }\end{array}$ \\
\hline Adland et al. (2004) & $\begin{array}{l}\text { Estimation of implied forward prices } \\
\text { for vessel prices and investigation of } \\
\text { the unbiasedness hypothesis }\end{array}$ & $\begin{array}{l}156 \text { monthly } \\
\text { prices }\end{array}$ & $1990-2003$ & $\begin{array}{l}\text { - The unbiasedness hypothesis is rejected in all cases } \\
\text { - Evidence of the presence of a risk premium }\end{array}$ \\
\hline $\begin{array}{l}\text { Kavussanos and Visvikis } \\
\text { (2004) }\end{array}$ & $\begin{array}{l}\text { Investigation of the lead-lag } \\
\text { relationship in returns and volatilities } \\
\text { between shipping spot freight and FFA } \\
\text { markets }\end{array}$ & 1,078 daily prices & $1997-2000$ & $\begin{array}{l}\text { - Bi-directional causality exists between spot and FFA } \\
\text { returns } \\
\text { - Uni-directional spillover from FFA to the spot market }\end{array}$ \\
\hline Kavussanos et al. (2004a) & $\begin{array}{l}\text { Examination of the impact of FFA } \\
\text { trading on volatility of spot freight } \\
\text { rates }\end{array}$ & 3,038 daily prices & 1989-2001 & $\begin{array}{l}\text { - FFA trading has a stabilising impact in the spot freight } \\
\text { rate market } \\
\text { - FFA trading has a decreases asymmetric volatility and } \\
\text { enhances the quality and speed of information flowing }\end{array}$ \\
\hline $\begin{array}{l}\text { Kavussanos et al. } \\
(2004 \mathrm{~b})\end{array}$ & $\begin{array}{l}\text { Investigation of the unbiasedness } \\
\text { hypothesis of FFA prices }\end{array}$ & $\begin{array}{l}240 \text { monthly } \\
\text { prices }\end{array}$ & 1996-2000 & $\begin{array}{l}\text { - FFA prices of one- and two-month prior to maturity } \\
\text { are unbiased predictors of the realised spot prices }\end{array}$ \\
\hline $\begin{array}{l}\text { Koekebakker and Adland } \\
(2004 a)\end{array}$ & $\begin{array}{l}\text { Examination of the volatility of } \\
\text { forward freight rates of time-charters }\end{array}$ & 555 weekly prices & 1992-2002 & $\begin{array}{l}\text { - Volatility of the forward curve is relatively high, } \\
\text { reaching a peak for the 1-year forward freight rate } \\
\text { contracts }\end{array}$ \\
\hline Batchelor et al. (2005) & $\begin{array}{l}\text { Examination of the relationship } \\
\text { between expected volatility and bid- } \\
\text { ask spreads in the FFA market }\end{array}$ & 897 daily prices & $1997-2000$ & $\begin{array}{l}\text { - Positive relationship between expected price volatility } \\
\text { and bid-ask spreads in the Panamax FFA market }\end{array}$ \\
\hline Alizadeh et al. (2007) & $\begin{array}{l}\text { Investigation of the unbiasedness } \\
\text { hypothesis of implied forward charter } \\
\text { rates in dry-bulk shipping }\end{array}$ & 754 weekly prices & 1989-2003 & $\begin{array}{l}\text { - Implied forward six-month time-charter rates are } \\
\text { unbiased predictors of the future freight rates } \\
\text { - Trading rules generate economic profits }\end{array}$ \\
\hline Batchelor et al. (2007) & $\begin{array}{l}\text { Examination of the forecasting } \\
\text { performance of time-series models for } \\
\text { spot freight rates and FFA prices }\end{array}$ & 1,080 daily prices & $1997-2001$ & $\begin{array}{l}\text { - Incorporation of information from FFA prices } \\
\text { enhances the forecasting performance of time-series } \\
\text { models for Panamax spot freight rates }\end{array}$ \\
\hline Kavussanos et al. (2007) & $\begin{array}{l}\text { Questionnaire survey for the use of } \\
\text { shipping derivatives among Greek } \\
\text { shipowners }\end{array}$ & 31 companies & - & $\begin{array}{l}\text { - Greek shipowners are reluctant to use FFAs for } \\
\text { reduction of freight rate risk due to thin trading } \\
\text { volume and high credit risk }\end{array}$ \\
\hline $\begin{array}{l}\text { Koekebakker et al. } \\
\text { (2007) }\end{array}$ & $\begin{array}{l}\text { Deriving a closed-form solution for } \\
\text { pricing Asian-style freight options }\end{array}$ & Case study & - & $\begin{array}{l}\text { - The proposed model assumes lognormal distribution } \\
\text { of the underlying spot freight rates. However, the } \\
\text { lognormality breaks down during the settlement } \\
\text { period due to the average-based settlement pricing } \\
\text { - To deal with this issue, the model suggests lognormal } \\
\text { approximation of volatility of spot fright rates during } \\
\text { the settlement period }\end{array}$ \\
\hline $\begin{array}{l}\text { Angelidis and } \\
\text { Skiadopoulos (2008) }\end{array}$ & $\begin{array}{l}\text { Investigation of the performance of } \\
\text { VaR and ETL models in forecasting } \\
\text { risks in dry-bulk and tanker markets }\end{array}$ & 1875 daily prices & 1999-2006 & $\begin{array}{l}\text { - Non-parametric specifications outperform parametric } \\
\text { methods }\end{array}$ \\
\hline Chou and Huang (2010) & $\begin{array}{l}\text { Investigation of the interactions } \\
\text { between dry-bulk FFA and steel } \\
\text { markets }\end{array}$ & 396 weekly prices & 2002-2009 & $\begin{array}{l}\text { - The global steel price index exhibits significant } \\
\text { forecasting power for the FFA prices }\end{array}$ \\
\hline Kavussanos et al. (2010) & $\begin{array}{l}\text { Investigation of the spillover effect } \\
\text { between freight rate and commodity } \\
\text { derivatives markets }\end{array}$ & $\begin{array}{l}821 \text { daily freight } \\
\text { rates }\end{array}$ & $2005-2008$ & $\begin{array}{l}\text { - Return and volatility spillovers are generally uni- } \\
\text { directional from commodity futures to FFAs }\end{array}$ \\
\hline $\begin{array}{l}\text { Samitas and Tsakalos } \\
(2010)\end{array}$ & $\begin{array}{l}\text { Investigation of the impact of the use } \\
\text { of shipping derivatives on company } \\
\text { value }\end{array}$ & $\begin{array}{l}116 \text { company- } \\
\text { quarters }\end{array}$ & $2005-2008$ & $\begin{array}{l}\text { - The use of shipping derivatives has a positive impact } \\
\text { on shipping company value by mitigating business } \\
\text { risks }\end{array}$ \\
\hline $\begin{array}{l}\text { Kavussanos and } \\
\text { Dimitrakopoulos (2011) }\end{array}$ & $\begin{array}{l}\text { Derivation of framework for tanker } \\
\text { shipping market risk measurement } \\
\text { using VaR and ETL }\end{array}$ & 2035 daily prices & 1998-2006 & $\begin{array}{l}\text { - Parametric GARCH and non-parametric Filtered } \\
\text { Historical Simulation outperform other specifications } \\
\text { in forecasting short-term freight rates } \\
\text { - For long-term forecasting, the scaled historical } \\
\text { simulation model is the most accurate method }\end{array}$ \\
\hline
\end{tabular}




\begin{tabular}{|c|c|c|c|c|}
\hline \multirow{2}{*}{ STUDY } & \multirow{2}{*}{ DESCRIPTION } & \multicolumn{2}{|c|}{ SAMPLE } & \multirow{2}{*}{ MAIN RESULTS } \\
\hline & & Observations & Period & \\
\hline Prokopczuk (2011) & $\begin{array}{l}\text { Examination of pricing and hedging } \\
\text { models of IMAREX freight futures }\end{array}$ & 262 weekly prices & $2005-2009$ & $\begin{array}{l}\text { - The inclusion of a second stochastic factor enhances } \\
\text { pricing accuracy and hedging effectiveness }\end{array}$ \\
\hline $\begin{array}{l}\text { Goulas and Skiadopoulos } \\
\text { (2012) }\end{array}$ & $\begin{array}{l}\text { Examination of the market efficiency } \\
\text { of dry-bulk IMAREX freight futures }\end{array}$ & 1,073 daily prices & $2005-2009$ & $\begin{array}{l}\text { - The IMAREX futures market is not informationally } \\
\text { efficient as trading strategies-based forecasts can } \\
\text { produce a positive risk premium }\end{array}$ \\
\hline Alizadeh (2013) & $\begin{array}{l}\text { Investigation of the trading volume- } \\
\text { price volatility relationship in the dry- } \\
\text { bulk FFA market }\end{array}$ & 217 weekly prices & $2007-2011$ & $\begin{array}{l}\text { - Positive and contemporaneous relationship between } \\
\text { trading volume and volatility } \\
\text { - Increases in price volatility lead to lower future FFA } \\
\text { trading activities }\end{array}$ \\
\hline Lyridis et al. (2013) & $\begin{array}{l}\text { Examination of the forecasting } \\
\text { performance of ANN models for FFA } \\
\text { prices }\end{array}$ & 1,060 daily prices & $2005-2009$ & $\begin{array}{l}\text { - Applied connectionist models generally yield better } \\
\text { accuracy with high success rates for modelling FFA } \\
\text { prices }\end{array}$ \\
\hline $\begin{array}{l}\text { Nomikos and Doctor } \\
\text { (2013) }\end{array}$ & $\begin{array}{l}\text { Investigation of the profitability of } \\
\text { market timing trading strategies in the } \\
\text { dry-bulk FFA market }\end{array}$ & 1,699 daily prices & $2005-2011$ & $\begin{array}{l}\text { - Trading rules generally outperform the benchmark } \\
\text { buy-and-hold strategy }\end{array}$ \\
\hline Nomikos et al. (2013) & $\begin{array}{l}\text { Valuation framework for options on } \\
\text { the average freight rate }\end{array}$ & Case study & - & $\begin{array}{l}\text { - A jump diffusion process enhances pricing accuracy } \\
\text { of the proposed model }\end{array}$ \\
\hline Wang and Teo (2013) & $\begin{array}{l}\text { Business model combining network } \\
\text { planning and bunker hedging in } \\
\text { container shipping }\end{array}$ & Case study & - & $\begin{array}{l}\text { - Integration of network planning and bunker hedging } \\
\text { activity enables shipping companies to achieve } \\
\text { optimal managerial decisions }\end{array}$ \\
\hline Kavussanos et al. (2014a) & $\begin{array}{l}\text { Investigation of the spillover effect } \\
\text { between dry-bulk FFA and commodity } \\
\text { derivatives market. }\end{array}$ & 868 daily prices & 2006-2009 & $\begin{array}{l}\text { - Agricultural commodity futures informationally lead } \\
\text { freight markets }\end{array}$ \\
\hline Li et al. (2014) & $\begin{array}{l}\text { Investigation of the spillover effects } \\
\text { between spot and FFA prices in tanker } \\
\text { shipping }\end{array}$ & 1,489 daily prices & 2006-2011 & $\begin{array}{l}\text { - Unilateral spillovers from 1-month FFA to spot } \\
\text { returns } \\
\text { - Bilateral volatility spillovers between spot freight rate } \\
\text { and FFA prices }\end{array}$ \\
\hline Zhang et al. (2014) & $\begin{array}{l}\text { Examination of the forecasting } \\
\text { performance of time-series models for } \\
\text { Capesize freight rates }\end{array}$ & 230 weekly prices & $2005-2009$ & $\begin{array}{l}\text { - Cointegration relationships between FFA and spot } \\
\text { freight rates, and between time-charter and spot rates } \\
\text { enhances forecasting performance of time-series } \\
\text { models }\end{array}$ \\
\hline Alizadeh et al. (2015a) & $\begin{array}{l}\text { Investigation of the hedging } \\
\text { performance of tanker FFAs }\end{array}$ & 442 weekly prices & $2005-2013$ & $\begin{array}{l}\text { - Regime-switching GARCH model improves hedging } \\
\text { effectiveness in in-sample estimation, while the } \\
\text { results are mixed in out-of-sample estimation }\end{array}$ \\
\hline Alizadeh et al. (2015b) & $\begin{array}{l}\text { Investigation of the impact of liquidity } \\
\text { risk on dry-bulk FFA returns }\end{array}$ & 306 weekly prices & $2008-2014$ & - Liquidity risk has a positive impact on FFA returns \\
\hline Adland and Jia (2017) & $\begin{array}{l}\text { Investigation of the time-varying } \\
\text { differential between trip-charter } \\
\text { average and simulated earnings from a } \\
\text { fleet of Capesize vessels } \\
\text { Examination of the physical basis risk } \\
\text { in dry-bulk shipping }\end{array}$ & 2,872 daily prices & $2002-2014$ & $\begin{array}{l}\text { - Increasing fleet size lowers basis risk, but the } \\
\text { diversification effect is relatively small } \\
\text { - Physical basis risk never disappears due to moving } \\
\text { average effect in earnings } \\
\text { - Physical basis risk is greater for short hedging } \\
\text { durations }\end{array}$ \\
\hline $\begin{array}{l}\text { Alexandridis } e t a l \text {. } \\
\text { (2017a) }\end{array}$ & $\begin{array}{l}\text { Investigation } \quad \text { of } \\
\text { transmission in returns and volatilities } \\
\text { of spot, futures and options in shipping }\end{array}$ & 849 daily prices & $2013-2016$ & $\begin{array}{l}\text { - Freight futures market informationally lead spot } \\
\text { freight rate market } \\
\text { - Freight options market informationally lag behind } \\
\text { both spot freight rate and freight futures markets }\end{array}$ \\
\hline $\begin{array}{l}\text { Alexandridis et al. } \\
(2017 \mathrm{~b})\end{array}$ & $\begin{array}{l}\text { Portfolio-based methodological } \\
\text { framework aiming to improve freight } \\
\text { rate risk management }\end{array}$ & 263 weekly prices & 2011-2016 & $\begin{array}{l}\text { - Decrease in freight rate risk up to } 48 \% \text { by holding a } \\
\text { diversified portfolio of freight rates } \\
\text { - An additional decrease of up to } 8 \% \text { by hedging freight } \\
\text { rate risk with futures contracts }\end{array}$ \\
\hline Kyriakou et al. (2017a) & $\begin{array}{l}\text { Valuation of freight options reflecting } \\
\text { mean-reverting property of freight } \\
\text { rates }\end{array}$ & 336 weekly prices & $2008-2014$ & $\begin{array}{l}\text { - The jump diffusion model incorporating mean- } \\
\text { reverting property of freight rates outperforms the } \\
\text { generic lognormal model in terms of pricing accuracy. }\end{array}$ \\
\hline Yin et al. (2017) & $\begin{array}{l}\text { Investigation of the causal relationship } \\
\text { between FFA and spot prices in dry- } \\
\text { bulk shipping }\end{array}$ & 1,730 daily prices & $2007-2013$ & $\begin{array}{l}\text { - Bi-directional causality between FFA and spot freight } \\
\text { rates } \\
\text { - Both FFA and spot prices follow a mean-reverting } \\
\text { process }\end{array}$ \\
\hline Adland et al. (2017a) & $\begin{array}{l}\text { Multivariate model for the dynamic } \\
\text { relationships of regional spot freight } \\
\text { rates }\end{array}$ & $\begin{array}{l}540 \text { weekly freight } \\
\text { rates }\end{array}$ & $2007-2015$ & $\begin{array}{l}\text { - Decomposing freight rates into a common market } \\
\text { factor and regional deviations } \\
\text { - Term structure of volatility and correlation between } \\
\text { the regional freight rates and the market factor }\end{array}$ \\
\hline Sun et al. (2018) & $\begin{array}{l}\text { Optimal combination hedge ratios for } \\
\text { a shipowner trading crude oil and dry } \\
\text { bulk freight rates simultaneously }\end{array}$ & 2,458 daily prices & $2005-2015$ & $\begin{array}{l}\text { - Significant volatility spillovers are found between } \\
\text { crude oil futures and FFAs, indicating that dynamic } \\
\text { cross-market interactions have impacts on the hedging } \\
\text { strategy }\end{array}$ \\
\hline
\end{tabular}


Appendix. List of Authors in Shipping Finance Research

\begin{tabular}{|c|c|c|c|c|c|c|c|}
\hline Author & Count & Author & Count & Author & Count & Author & Count \\
\hline Abdullah, A. & 1 & Fan. L. & 1 & Li, K. X. & 1 & Sødal, S. & 3 \\
\hline Abouarghoub, W. & 1 & Forrest, M. & 1 & Liu, H. & 1 & Song, D.-W. & 1 \\
\hline Acciaro, $\mathrm{M}$. & 1 & $\mathrm{Fu}, \mathrm{X}$. & 1 & $\mathrm{Li}, \mathrm{Y}$. & 1 & Souza, C. M. & 1 \\
\hline Adland, R. & 15 & Fusillo, M. & 1 & Louca, C. & 2 & Spinler, S. & 1 \\
\hline $\begin{array}{l}\text { Ahrenda, M. } \\
\text { Albertijn, S. }\end{array}$ & $\begin{array}{l}1 \\
2\end{array}$ & Gavalas, D. & 2 & Lozinskaia, A. & 1 & Stent, A. F. & 3 \\
\hline Alexandridis, G. & 3 & Glen, D. R. & 1 & Luo, M. & 1 & Strandenes, S. P. & 1 \\
\hline Alexandrou, G. & 1 & Gong, S. X. & 3 & Lyridis, D. & 1 & Stratis, N. & 1 \\
\hline Alexopoulos, I. & 1 & Goss, R. & 1 & Marcoulis, S. N. & 6 & Sun, $\mathrm{X}$. & 1 \\
\hline Alizadeh, A. H. & 19 & Goulas, L. & 1 & Mason, K. J. & 1 & Syriopoulos, T. C. & 7 \\
\hline An, Y. H. & 1 & Goulielmos, A. M. & 2 & Mayr, T. P. & 1 & Tamvakis, M. N. & 1 \\
\hline Andreou, P. C. & 2 & Goulielmou, M. A. & 1 & Meersman, H. & 1 & Tegtmeier, L. & 3 \\
\hline Andriosopoulos, $\mathrm{K}$. & 2 & Gounopoulos, D. & 4 & Meier, I. & 1 & Teo, C.-C. & 1 \\
\hline Angelidis, $\mathrm{T}$. & 1 & Grammenos, C. Th. & 7 & Menachof, D. A. & 2 & Tezuka, K. & 1 \\
\hline Arkoulis, A. G. & 2 & Greenwood, R. & 1 & Menzel, C. & 1 & Thanopoulou, H. & 1 \\
\hline Assis, L. F. & 1 & Grelck, M. B. & 1 & Merika, A. A. & 5 & Theodoropoulou, S. & 1 \\
\hline Axarloglou, $\mathrm{K}$. & 1 & Haider, J. J. & 1 & Merikas, A. G. & 8 & Theotokas, I. N. & 2 \\
\hline Balliauw, M. & 1 & Haigh, M. S. & 2 & Mitroussi, K. & 1 & Thomakos, D. D. & 1 \\
\hline Bang, H.-S. & 2 & Haller, R. & 1 & Miyashita, K. & 1 & Thomas, H. M. & 1 \\
\hline Batchelor, R. & 3 & Hanson, S. G. & 1 & Morris, J. & 1 & Thuong, L. T. & 1 \\
\hline Bendall, $\mathrm{H}$. & 3 & Hansson, D. & 1 & Nam, H. J. & 1 & Tigka, N. & 1 \\
\hline Benth, F. E. & 1 & Haralambides, H.E. & 1 & Negenborn, R.R. & 1 & Topalov, M & 1 \\
\hline Berg-Andreassen, J. A. & 1 & Hassan, R. & 1 & Nomikos, N. K. & 18 & Triantafyllou, A. & 2 \\
\hline Bessler, W. & 1 & Holt, M. T. & 1 & Noraas, J. & 1 & Tsakalos, I. & 1 \\
\hline Boulougouris, E. & 1 & $\mathrm{Hu}, \mathrm{H}$. & 1 & Notteboom, T. & 1 & Tsatsaronis, M. & 2 \\
\hline Brooks, M.R. & 1 & Huang, B.-C. & 1 & Nounis, C. & 1 & Tsionas, M. G. & 2 \\
\hline Bulut, E. & 1 & Huang, C.-H. & 1 & $\begin{array}{l}\text { Pak, M.-S. } \\
\text { Panayides, P. M. }\end{array}$ & $\begin{array}{l}1 \\
7\end{array}$ & Tsouknidis, D. A. & 4 \\
\hline Cape, M. B. & 1 & Ioardanis, S. & 1 & Papapostolou, N. C. & 10 & Tvedt, J. & 2 \\
\hline Chang, C.-C. & 1 & Ishii, M. & 1 & Parola, F. & 1 & van de Voorde, E. & 1 \\
\hline Chang, H. B. & 1 & Ishizaka, M. & 1 & Penikas, H. & 1 & van Dellen, S. & 1 \\
\hline Chang, Y.-T. & 1 & Iversen, R. S. & 1 & Persico, L. & 1 & Vischer, S. L. & 1 \\
\hline Chen, D.-H. & 1 & Jenssen, J. & 1 & Petropoulos, T. & 1 & Visvikis, I. D. & 21 \\
\hline 2Chen, F. & 1 & $\mathrm{Jia}, \mathrm{H}$. & 5 & Pettit, S. J. & 1 & von der Wense, L. & 1 \\
\hline Chen, S. & 2 & Johns, M. & 1 & Pires, F. C. M. & 1 & Wambach, M. & 1 \\
\hline Choi, N. Y. H. & 1 & Jørgensen, P. L. & 1 & Polemis, D. & 1 & Wang, G.W & 1 \\
\hline Chou, H.-C. & 2 & Juell-Skielse, A. & 1 & Pouliasis, P. K. & 6 & Wang, X. & 1 \\
\hline Chou, M.-T. & 1 & Kalouptsidi, M. & 1 & Prigge, $\mathrm{S}$. & 2 & Woo, S.-H. & 1 \\
\hline Clintworth, M. & 1 & Kang, H-W. & 1 & Prokopczukm M. & 1 & Xu, J. J. & 1 \\
\hline Constantinidou, I. & 1 & Kappou, K. & 1 & Psifia, E. M. & 2 & Yang, Z. & 1 \\
\hline Cullinane, K. P. B. & 7 & Karli, C. & 1 & Qi, G. & 1 & Ye, H.-Q. & 1 \\
\hline Dai, L. & 1 & Kassim, S. & 1 & Rand $\varnothing \mathrm{y}, \mathrm{T}$. & 1 & Yeo, H.-J. & 1 \\
\hline Daleziou, S. & 1 & Kavussanos, M. G. & 39 & Rau, P. & 1 & Yin, J. & 1 \\
\hline De Giovanni, D. & 1 & Kenourgios, D. F. & 1 & Richter, T. & 1 & Yip, T. L. & 3 \\
\hline $\begin{array}{l}\text { Del Gaudio, B. L. } \\
\text { Dikos, G. N. }\end{array}$ & $\begin{array}{l}1 \\
1\end{array}$ & Koekebakker, S. & 9 & Ritchie, P. & 1 & Yolland, J. B. & 1 \\
\hline Dimitrakopoulos, D. N. & 4 & Koufopoulos, D. & 2 & Rousos, E.-P. & 1 & Yoshida, S. & 2 \\
\hline Dimitras, A. I. & 1 & Koutroubousis, G. & 1 & Sahoo, S. R. & 2 & Zacharioudakis, $\mathrm{P}$. & 1 \\
\hline Dinwoodie, J. & 1 & Kuo, C.-C. & 1 & Samitas, A. G. & 2 & Zarkos, S. & 1 \\
\hline Doctor, K. & 1 & Kyriakou, I. & 5 & Satta, G. & 2 & Zeng, Q. & 1 \\
\hline Doumpos, M. & 1 & Lagoudis, I. N. & 1 & Schilling, D. & 1 & Zeng, Y. Y. & 1 \\
\hline Down, J. & 1 & Laios, A. & 1 & Schröder, H. & 2 & Zhang, J. & 1 \\
\hline Drobetz, W. & 10 & Lambertides, N. & 1 & Shi, W. & 1 & Zhao, X. & 1 \\
\hline Duru, O. & 1 & Lauenstein, $\mathrm{P}$. & 1 & Simic, A. K. & 1 & Zheng H. & 1 \\
\hline \multirow[t]{2}{*}{ Evans, J. J. } & 1 & Lee, B. S. & 2 & Singh, M. & 1 & Zheng, J. & 1 \\
\hline & & $\begin{array}{l}\text { Lee, K. R. } \\
\text { Leggate, H. K. }\end{array}$ & $\begin{array}{l}1 \\
1\end{array}$ & Skiadopoulos, G. & 2 & Zheng, S. & 1 \\
\hline
\end{tabular}


Note: The list of authors is in alphabetaical order and the count includes authors of peer reviewed journal papers as well as select books and book chapters. 